\title{
Treatment of Combined Sewer Overflows Using Ferrate (VI)
}

Rohan Gandhi, The University of Western Ontario

Supervisor: Dr. Ajay K. Ray, The University of Western Ontario

A thesis submitted in partial fulfillment of the requirements for the Master of Engineering Science degree in Chemical and Biochemical Engineering

(C) Rohan Gandhi 2013

Follow this and additional works at: https://ir.lib.uwo.ca/etd

Part of the Environmental Engineering Commons, and the Other Chemical Engineering Commons

\section{Recommended Citation}

Gandhi, Rohan, "Treatment of Combined Sewer Overflows Using Ferrate (VI)" (2013). Electronic Thesis and Dissertation Repository. 1736.

https://ir.lib.uwo.ca/etd/1736

This Dissertation/Thesis is brought to you for free and open access by Scholarship@Western. It has been accepted for inclusion in Electronic Thesis and Dissertation Repository by an authorized administrator of Scholarship@Western. For more information, please contact wlswadmin@uwo.ca. 
(Thesis format: Integrated Article)

by

Rohan Gandhi

Graduate Program in Engineering Science

Department of Chemical and Biochemical Engineering

A thesis submitted in partial fulfillment

of the requirements for the degree of

Master of Engineering Science

The School of Graduate and Postdoctoral Studies

The University of Western Ontario

London, Ontario, Canada

(C) Rohan Gandhi 2013 


\begin{abstract}
Prevention of pollution from combined sewer overflows (CSOs) is currently a major concern due to their impact on aquatic and human environment. With the stringent regulations related to the CSOs treatment, it is necessary to develop an efficient, fast and low cost treatment technique that meets the applicable criteria. In this work, the comprehensive study was done to determine the efficiency of ferrate (VI) for the treatment of CSOs. At a Fe (VI) dose of $0.24 \mathrm{mg} / 1$, TCOD, SCOD, TBOD $5, \mathrm{SBOD}_{5}$, TSS, VSS, TP, TN and soluble TN removal efficiencies of 71\%, 75\%, 69\%, 68\%, 72\%, $83 \%, 64 \%, 38 \%$ and $36 \%$ respectively were achieved. Kinetic studies revealed that a contact time of only 15 minutes is sufficient to achieve secondary effluent criteria. An innovative technique of using primary sludge (PS) and thickened waste activated sludge (TWAS) as a source for the in-situ synthesis of ferrate was explored. A comparative study of treatment efficiencies achieved by Fe (VI) generated from different sources was done. At $0.1 \mathrm{mg} / \mathrm{l}$ dose of Fe (VI) synthesized from PS, TCOD, SCOD, TSS, VSS, TP and TN removal efficiencies of $60 \%, 62 \%, 63 \%, 67 \%, 30 \%$ and $25 \%$ respectively were achieved.
\end{abstract}

Keywords: Combined Sewer Overflows (CSOs), ferrate (VI), primary sludge (PS), thickened waste activated sludge (TWAS) 


\section{Co-authorship}

Chapter 3: Treatment of Combined Sewer Overflows using Ferrate (VI)

Authors: Rohan Gandhi, Ajay K. Ray, George Nakhla

Rohan Gandhi performed all the experimental work and data analysis under the guidance of Dr. Ajay K. Ray and Dr. George Nakhla. The draft of this manuscript was written by

Rohan Gandhi. Modification of the draft was undertaken under the close supervision of Dr. George Nakhla and Dr. Ajay K. Ray. The final version was submitted to the Water Environment Research (WER) Journal. 


\section{Acknowledgments}

I would like to express the deepest appreciation to my supervisors Dr. Ajay K. Ray and

Dr. George Nakhla for taking me under their wings and making me familiar to the area of research. Without their guidance and persistent help this work would not have been possible.

I would like to extend my appreciation to Dr. Virender K. Sharma for always being available to share his knowledge about Ferrate (VI).

I would sincerely like to thank Dr. Ahmed Eldyasti for training me with analytical methods and helping me with wastewater and sludge collection. I am grateful to Dr. Syed Elbeshbishy for making me well versed with iron analysis.

Special thanks to Fate Hashemi for ordering the chemicals on my behalf and for continuous laboratory assistance.

I would like to thank my colleagues Samindika, Naemeih, Ghodseih, Nillohit, Gloria, Shubhajit, Pegah and Noshin for all the help and support to complete my research. I would like to thank my best friends Dhiraj and Sangam for entertaining me throughout this two year journey.

I would like to thank GOD for giving me strength to complete this work. Finally, I owe a debt of gratitude to my loving parents, dear sister and caring family for continuous encouragement. I would like to dedicate this work to them. 


\section{Table of Contents}

Abstract

Co-authorship $\quad$ iii

Acknowledgements $\quad$ iv

Table of Contents $\quad$ V

List of Tables viii

$\begin{array}{ll}\text { List of Figures } & \text { ix }\end{array}$

List of Appendices $\quad$ X

Nomenclature $\quad x i$

Abbreviations $\quad$ xi

Chapter 1: Introduction 1

$1.1 \quad$ Background 1

1.2 Structure of the thesis 6

$\begin{array}{lll}1.3 & \text { References } & 7\end{array}$

Chapter 2: Literature Review 13

2.1 Combined sewer overflows (CSOs) 13

$\begin{array}{lll}\text { 2.1.1 Impacts of CSOs } & 14\end{array}$

2.1.2 Factors affecting the concentrations of pollutants in CSOs 15

2.2 Regulations governing discharge of CSOs 16

$\begin{array}{lll}2.2 .1 & \text { Laws } & 16\end{array}$

$\begin{array}{lll}\text { 2.2.2 CSO Control Policy } & 17\end{array}$

2.3 CSO treatment techniques 19

$\begin{array}{lll}2.3 .1 & \text { Wetlands } & 19\end{array}$

$\begin{array}{ll}\text { 2.3.2 Settling tanks } & 22\end{array}$ 
2.3.3 Chemically Enhanced Primary Treatment (CEPT) 23

2.3.4 High rate ballasted clarification treatment 25

$\begin{array}{lll}\text { 2.3.4.1 Actiflo } & 25\end{array}$

$\begin{array}{lll}\text { 2.3.4.2 DensaDeg } & 27\end{array}$

$\begin{array}{lll}\text { 2.3.4.3 CoMag } & 29\end{array}$

$2.4 \quad$ Ferrate (VI) 31

2.4.1 Applications of ferrate (VI) 32

2.4.2 Synthesis of ferrate (VI) 34

2.4.2.1 Electrochemical synthesis method 34

2.4.2.2 Dry synthesis method 36

2.4.2.3 Wet synthesis method 36

$\begin{array}{lll}\text { 2.4.3 Ferrate Analysis } & 37\end{array}$

2.4.3.1 Volumetric titration method 37

$\begin{array}{lll}\text { 2.4.3.2 UV-Visible spectroscopy } & 37\end{array}$

2.5 Objectives of present research 38

2.6 References 39

Chapter 3: Treatment of Combined Sewer Overflows using Ferrate (VI) 51

3.1 Introduction $\quad 51$

3.2 Materials and Methods $\quad 55$

$\begin{array}{lll}3.3 & \text { Results and Discussions } & 60\end{array}$

$\begin{array}{lll}3.4 & \text { Conclusions } & 74\end{array}$

$\begin{array}{lll}3.5 & \text { References } & 75\end{array}$

Chapter 4: Conclusions and Recommendations 81

$\begin{array}{lll}4.1 & \text { Conclusions } & 81\end{array}$

$\begin{array}{lll}4.2 & \text { Recommendations } & 82\end{array}$ 
Appendices

Curriculum Vitae 


\section{List of Tables}

Table 2.1 Pollutants and their principal consequences 15

Table 2.2 Design criteria of constructed wetlands (CW) in France and Italy 21

Table 2.3 North American Treatment operational performance 21

Table 2.4 Design criteria for retention basin (RB) in Germany 23

Table 3.1 Raw waste water (RWW) characteristics 57

Table 3.2 Characteristics of PS and TWAS 59

Table 3.3 Treatment Efficiency of Ferrate VI (0.24 mg/l dose) 63

Table 3.4 Comparative performance of ferrate (VI) produced from different 69 source

Table 3.5 Contribution of the coagulation effect of Ferrate (VI) to COD 71 removal

Table 3.6 Comparison between the Secondary Treatment Effluent Criteria and 73 the removal of water characteristics achieved by Fe (VI) synthesized from different iron sources 


\section{List of Figures}

$\begin{array}{lll}\text { Figure 2.1 Combined Sewer Overflows } & 14\end{array}$

Figure 2.2 Schematic Diagram of Chemically Enhanced Primary Treatment 24

Figure 2.3 Actiflo Process Diagram 26

Figure 2.4 Schematic representation of DensaDeg process 28

$\begin{array}{lll}\text { Figure 2.5 CoMag Process } & 30\end{array}$

$\begin{array}{lll}\text { Figure 2.6 Structure of Ferrate } & 31\end{array}$

Figure 2.7 UV-Vis spectrum of Fe (VI) 38

Figure 3.1 Treatment efficiency of different doses of Fe (VI) at neutral pH 61

Figure 3.2 Effect of $\mathrm{pH}$ on the treatment performance of Fe (VI) doses, (a) 62 pH 6; (b) $\mathrm{pH} \mathrm{7;} \mathrm{(c)} \mathrm{pH} 8$; (d) $\mathrm{pH} 9$

Figure 3.3 Plot of soluble organic nitrogen (SON) vs. soluble chemical 64 oxygen demand (SCOD)

Figure 3.4-a Effect of 0.24 mg/l ferrate (VI) dose on Concentration of PCOD 65 and SCOD with respect to time.

Figure 3.4-b Effect of $0.24 \mathrm{mg} / \mathrm{l}$ ferrate (VI) dose on Concentration of TN, $\quad 65$ STN, TP and $\mathrm{NH}_{4}$ with respect to time.

Figure 3.5 Plot of 1/Concentration of PCOD and SCOD vs. time for the 66 ferrate dose of $0.24 \mathrm{mg} / \mathrm{l}$. (Kinetic study)

Figure 3.6 Influent and Effluent concentrations of water quality parameters 68 obtained from ferrate doses prepared from different sources.

Figure 3.7 Treatment efficiency of different doses of Fe (VI) synthesized 72 from digested PS filtrate. 


\section{List of Appendices}

Appendix A Applicability of Fe (VI) for CSO treatment (Raw Data) 84

Appendix B Optimization of Fe (VI) dose (Data used for Figure 3.2) 87

Appendix C Kinetics (Data used for Figure 3.4) 90

Appendix D Performance of Fe (VI) synthesized from various doses (Data used 92 for Figure 3.6)

Appendix E Performance of $\mathrm{NaOCl}$ doses (Control) (Data used for Table 3.4) 92

Appendix F Optimization of Fe (VI) synthesized from digested PS filtrate 93 (Data used for Figure 3.7) 


\section{Nomenclature}

$\begin{array}{llc}\text { TCOD } & \text { Total Chemical Oxygen Demand } & (\mathrm{mg} / \mathrm{l}) \\ \text { SCOD } & \text { Soluble Chemical Oxygen Demand } & (\mathrm{mg} / \mathrm{l}) \\ \text { PCOD } & \text { Particulate Chemical Oxygen Demand } & (\mathrm{mg} / \mathrm{l}) \\ \text { TBOD }_{5} & \text { Total Biochemical Oxygen Demand (5-day) } & (\mathrm{mg} / \mathrm{l}) \\ \text { SBOD }_{5} & \text { Soluble Biochemical Oxygen Demand (5-day) } & (\mathrm{mg} / \mathrm{l}) \\ \text { TSS } & \text { Total Suspended Solids } & (\mathrm{mg} / \mathrm{l}) \\ \text { VSS } & \text { Volatile Suspended Solids } & (\mathrm{mg} / \mathrm{l}) \\ \text { TN } & \text { Total Nitrogen } & (\mathrm{mg} / \mathrm{l}) \\ \text { STN } & \text { Soluble Total Nitrogen } & (\mathrm{mg} / \mathrm{l}) \\ \text { TP } & \text { Total Phosphorous } & (\mathrm{mg} / \mathrm{l}) \\ \text { SON } & \text { Soluble Organic Nitrogen } & (\mathrm{mg} / \mathrm{l}) \\ \text { PS } & \text { Primary Sludge } & \\ \text { TWAS } & \text { Thickened Waste Activated Sludge } & \end{array}$

\section{Abbreviations}

$\begin{array}{ll}\text { dig. } & \text { digested } \\ \text { avg } & \text { average } \\ \text { gpm/sf } & \text { gallons per minute per square feet } \\ \mathrm{nm} & \text { nanometer } \\ \mu \mathrm{m} & \text { microns (micrometer) }\end{array}$




\section{Chapter 1}

\section{Introduction}

\subsection{Background}

The growing population has led to a significant increase in the generation of wastewater, challenging the capacity of the collection system. Many municipalities are still served by combined sewers carrying the domestic sewage, industrial wastewater and stormwater runoff in the single pipe (Metcalf and Eddy, 2003). During a wet weather event, the hydraulic capacity of the combined sewer exceeds and the excess flow is discharged to the receiving waters as a combined sewer overflow (CSO) to prevent flooding and backup (Zukovs and Marsalek, 2004). Untreated wastewater when mixed with the receiving stream disturbs the aesthetics and can lead into major aquatic as well as human health damage (EPA, 2001). In order to keep the life cycle of environment intact, treatment of CSOs has become a major concern. To mitigate the impacts by CSOs, numerous efforts have been taken (Zukovs and Marsalek, 2004), such as:

- Separating the sewers, to fully isolate domestic sewage and stormwater runoff (EPA, 1999a).

- Constructing the storage tanks to retain CSOs, till the availability of WWTP to treat the loading (EPA, 1999b).

- Upgrading the sewage treatment plant capacity, to handle the excess loading (Zukovs and Marsalek, 2004).

Undertaking these CSO mitigation technologies have certain limitations, for example, land availability, and is also not economically viable. Concerns regarding these 
limitations led to the development of few patented physical - chemical treatment processes like Actiflo (USFilter, Kruger Products, Cary, North Carolina), DensaDeg (Infilco Degremont, Inc., Richmond, Virginia) and CoMag (Siemens, inc., Alpharetta, Georgia). These are all high rate ballasted clarification treatment processes (EPA 2013). In Actiflo process, the colloids are destabilized by the addition of coagulants. Polymer is added to aid flocculation along with the microsand, a ballast material, which provides large surface area to prepare floc and aids sedimentation (Blumenschein et al., 2006; EPA, 2008; Landon et al., 2006). The TSS and $\mathrm{BOD}_{5}$ removal by the $32.8 \mathrm{~L} / \mathrm{s}$ hydraulic capacity, pilot Actiflo plant, located at Southeast Water Pollution Control Plant (SEWPCP) in San Francisco, California, were reported to be in the range of $70-80 \%$ and $50-65 \%$ respectively, for $80 \mathrm{mg} / \mathrm{FeCl}_{3}$ dose and $1 \mathrm{mg} / \mathrm{l}$ polymer dose. The retention time of 13 minutes was reported (Jolis and Ahmad, 2004). DensaDeg process, a combination of coagulation, weighted flocculation and Lamella settling uses thickened recirculated sludge as ballast. The DensaDeg system situated at the Water Pollution Control Station (WPCS) at the City of Akron, Ohio, handling the surface overflow rate (SOR) of 40 gpm/sf, removed $83 \%$ TSS and 55\% BOD $_{5}$ using $85 \mathrm{mg} / 1$ ferric chloride and $0.77 \mathrm{mg} / \mathrm{l}$ polymer dose (Frank and Smith III, 2006). The typical hydraulic retention time (HRT) of DensaDeg process is in the range of 15-22 min (EPA 2003). CoMag, based on the same concept of Actiflo and DensaDeg, uses magnetite as ballast for high rate sedimentation (McHale, 2011). This process has mainly been used for the enhanced removal of phosphorous from the secondary effluent (EPA, 2008) and is now being used for CSO treatment considering its high suspended solids removal efficiency (Backman and Irwin, 2012). The typical removal efficiencies of TSS, BOD 5 and TP achieved by CoMag 
treatment plant are in the range of 70-90\%, 40-50\% and 85-95\% respectively (Pratt et al., 2008; Hardy, 2008; Backman and Irwin, 2012). The HRT is in the range of 5-15 min depending on the plant capacity (Backman and Irwin, 2012) and has faster start up time as compared to Actiflo and DensaDeg (Dittami, 2008). Chemically Enhanced Primary Treatment (CEPT) technique is also being used for CSO treatment (Mouri et al., 2013; Haydar and Aziz, 2009). In this process, the pollutants are removed by coagulation and flocculation enhanced by the addition of chemicals. The CEPT process located at Ipiranga WWTP, Sao Paulo, Brazil observed $62 \%, 58 \%, 80 \%$ removal of COD, $\mathrm{BOD}_{5}$ and TSS respectively for the flow rate of $50 \mathrm{~L} / \mathrm{s}$ and the chemical doses of $50 \mathrm{mg} / \mathrm{l}$ ferric chloride and $0.5 \mathrm{mg} / \mathrm{l}$ soluble polymer (Bourke Jr., 2000).

All the above mentioned processes come with few limitations:

- Soluble organics and nitrogen from wastewater can't be removed (Plum et al., 1998; EPA, 2013), which possess a major threat to aquatic environment and can also affect human health.

- Many chemicals are required to be dosed in the system which is not favorable to the environment and necessitates more maintenance (EPA, 2003).

- Startup time required by Actiflo, DensaDeg and CoMag is high and is in the range of 15-30 minutes (EPA 2003; Metcalf and Eddy, 2003; Dittami, 2008), which can result into the discharge of the untreated wastewater to the receiving stream during the wet weather event.

All the concerns regarding these limitations can be alleviated by developing of a low cost oxidation and coagulation, CSO treatment process with no start up time and short contact 
time. Looking at its numerous properties, and benefits reported by the researchers (Jiang and Lloyd, 2002; Sharma et al., 2005), ferrate (VI) promises to be the potential chemical that can meet these criteria.

Ferrate (VI) $\left(\mathrm{FeO}_{4}{ }^{2-}\right)$ is a strong oxidizing agent (Jiang et al., 2006; Tiwari et al., 2005) and also is a dual benefit chemical, as it performs oxidation and coagulation in single dose (Sharma et al., 2005; Lee et al., 2009). Fe (VI) gets reduced to Fe (III) ions or ferric hydroxide, known for their coagulating properties (Jiang et al., 2006; Lee et al., 2009).

There are numerous findings reported by researchers on the Fe (VI) performance as an oxidant, coagulant and disinfectant in treatment of water and wastewater. Ferrate (VI) successfully oxidized chlorinated phenols (Graham et al., 2004), arsenic (Lee et al., 2003), humic substances (Lim and Kim, 2010), cyanides (Flip et al., 2011), glucose, fructose, maltose, sucralose (Sharma et al., 2012), steroidal estrogens from dairy waste lagoon effluent (Remsberg et al., 2008) and ibuprofen (Sharma and Mishra, 2006). The use of ferrate (VI) for removal of heavy metals (Cu, Mn, Zn) (Lim and Kim, 2010), coagulation of colloidal particles (Jiang et al., 2001) and removal of color (Jiang and Wang, 2003) from water has been reported. Availability of literature on wastewater treatment using Fe (VI) is scarce, which can be related to the unstable nature of aqueous Fe (VI) (Jiang and Lloyd, 2002; Sharma et al; 2005) and also to the high cost required for the preparation of solid Fe (VI) (Sharma et al., 2005). Ferrator, a patented onsite ferrate preparation and treatment reactor, was developed by Ferrate Treatment Technologies to address the concerns related to the instability of Fe (VI) (Ciampi and Daly, 2009). This reactor which synthesizes ferrate by wet oxidation method is being used for disinfection, color removal, destruction of emerging contaminants and odor control (Alig et al., 2011). 
Onsite ferrate (VI) synthesis by electrochemical method has been reported by Jiang et al., (2009). The removal of $80 \%$ of TSS, $70 \%$ of TCOD and $90 \%$ TP from wastewater was achieved at a dose of around $2 \mathrm{mg} / \mathrm{l}$ of Fe (VI) generated electrochemically (Stanford et al., 2010). The soluble organics removal was not investigated.

Ferrate (VI) can generally be synthesized by three oxidation methods, (1) dry oxidation, (2) wet oxidation and (3) electrochemical oxidation (Tiwari et al., 2005; Sharma et al., 2005). In dry oxidation synthesis method, ferric salt and an oxidant are heated at elevated temperature to produce Fe (VI) (Kopelev et al., 1992). This synthesis method is dangerous and is rarely used as high temperatures are required for production of Fe (VI). Wet oxidation method is the most commonly used technique for the production of $\mathrm{Fe}$ (VI) (Tiwari et al., 2005; Jiang and Lloyd, 2002). In this method, ferrous and ferric salts are oxidized in strong alkaline medium to produce ferrate (VI) (White and Franklin, 1998). The yield achieved is very low and the aqueous ferrate (VI) produced requires further separation techniques to prepare solid ferrate (VI) (Sharma et al., 2005). In electrochemical oxidation method, anode, made of iron or iron salt, is oxidized in a strong electrolyte using a desired anode potential to produce sodium or potassium ferrate (Jiang and Lloyd, 2002).

Wastewater sludges contain iron (Jenkins et al., 1981), as Iron (II) and Iron (III) salts are used as coagulants and precipitants for phosphorous and odor removal in many wastewater treatment plants (Jiang and Graham, 1998; Perkowski and Kos, 2002). The sludges have never been used as an iron source for the generation of ferrate (VI) and can be attributed to the unavailability of exact speciation of iron in municipal sludges and variability of sludge composition. 
Based on the above, the objectives of the present work are:

- To evaluate the performance of $\mathrm{Fe}(\mathrm{VI})$ for the treatment of CSOs, monitoring the removal efficiencies of soluble organics and nutrients.

- To synthesize ferrate using primary sludge (PS) and Thickened waste activated sludge (TWAS) as an in-situ iron source and also by using ferrous sulfate heptahydrate $\left(\mathrm{FeSO}_{4} .7 \mathrm{H}_{2} \mathrm{O}\right)$, a pure iron source.

- To compare the treatment efficiencies of $\mathrm{Fe}(\mathrm{VI})$ generated from various iron source and to assess the performance with respect to the secondary effluent criteria proposed by US EPA.

\subsection{Structure of the thesis}

The thesis is written in "Integrated-Article Format" and is divided into the following chapters:

Chapter 1 describes the research background and the structure of the thesis.

Chapter 2 presents the review of the existing work related to the research, identifying the research gaps.

Chapter 3 discusses the efficiency of commercial grade as well as laboratory synthesized ferrate (VI) for the treatment of CSOs.

Chapter 4 concludes the thesis by summarizing the conclusions of the research and pointing out the future research directions. 


\subsection{References}

Alig, C.; Daly, L.; Huban, C.; Casson, L. (2011) Ferrate versus Chlorine Disinfection:

Disinfection By-Product Reduction and Other Benefits. Proceedings of the Water Environment Federation, Cincinnati, Ohio, April 10-12, pp. 350-355.

Bourke Jr., M. R. (2000) Full Scale Study of Chemically Enhanced Primary Treatment in Riviera de Sao Lourenco, Brazil (Doctoral dissertation, Massachusetts Institute of Technology).

Blumenschein, C. D.; Latker, E.; Banerjee, K. (2006) Sand Ballasted High Rate Clarification Process for Treatment of Process Water. IWC, 6, 20.

Backman, R.C.; and Irwin, J. (2012) Advanced Nutrient Removal and Capacity Expansion Using BioMag and CoMag Ballasted Solids Wastewater Technologies. Siemens water technologies.

Ciampi, L. E.; Daly, L. J. (2009) U.S. Patent No. 7,476,324. Washington, DC: U.S. Patent and Trademark Office.

Dittami, J. (2008) Phosphorous Reduction in the Assabet River. Doctoral dissertation; Worcester Polytechnic Institute.

Frank, D. A.; Smith III, T. F. (2006) Side By Side By Side The Evaluation of Three High Rate Process Technologies for Wet Weather Treatment.

Filip, J.; Yngard, R. A.,; Siskova, K.; Marusak, Z.; Ettler, V.; Sajdl, P.; Sharma, V.K.; Zboril, R. (2011) Mechanisms and Efficiency of the Simultaneous Removal of Metals 
and Cyanides by Using Ferrate (VI): Crucial Roles of Nanocrystalline Iron(III) Oxyhydroxides and Metal Carbonates. Chemistry-a European Journal, 17, 10097-10105.

Graham, N.; Jiang, C. C.; Li, X. Z.; Jiang, J. Q.; Ma, J. (2004) The Influence of pH on the Degradation of Phenol and Chlorophenols by Potassium Ferrate. Chemosphere, 56, 949956.

Hardy, C. (2008) Assabet River and Phosphorous Removal Options.

Haydar, S.; Aziz, J. A. (2009) Characterization and Treatability Studies of Tannery Wastewater using Chemically Enhanced Primary Treatment (CEPT)—A Case Study of Saddiq Leather Works. Journal of hazardous materials, 163, 1076-1083.

Jenkins, R. L.; Scheybeler, B. J.; Smith, M. L.; Baird, R.; Lo, M. P.; Haug, R. T. (1981) Metals Removal and Recovery from Municipal Sludge. Journal (Water Pollution Control Federation), 25-32.

Jiang, J. Q., \& Graham, N. J. (1998). Pre-Polymerized Inorganic Coagulants and Phosphorus Removal by Coagulation- A Review. Water SA, 24, 237-244.

Jiang, J. Q.; Lloyd, B.; Grigore, L. (2001) Preparation and Evaluation of potassium Ferrate as an Oxidant and Coagulant for Potable Water Treatment. Environmental Engineering Science, 18, 323-328.

Jiang, J. Q.; Lloyd, B. (2002) Progress in the Development and Use of Ferrate (VI) Salt as an Oxidant and Coagulant for Water and Wastewater Treatment. Water Research, 36, 1397-1408. 
Jiang, J.Q.; Wang, S. (2003) Enhanced Coagulation with Potassium Ferrate (VI) for Removing Humic Substances. Environmental Engineering Science, 20, 627-633.

Jolis, D.; Ahmad, M. L. (2004) Evaluation of High-Rate Clarification for Wet-WeatherOnly Treatment Facilities. Water Environment Research, 474-480.

Jiang, J. Q.; Wang, S.; Panagoulopoulos, A. (2006) The Exploration of Potassium Ferrate (VI) as a Disinfectant/Coagulant in Water and Wastewater Treatment. Chemosphere, 63, 212-219.

Jiang, J. Q.; Stanford, C.; Alsheyab, M. (2009) The Online Generation and Application of Ferrate (VI) for Sewage Treatment-A Pilot Scale Trial. Separation and Purification Technology, 68, 227-231.

Kopelev, N. S.; Perfiliev, Y. D.; Kiselev, Y. M. (1992) Mössbauer Study of Sodium Ferrates (IV) and (VI). Journal of Radioanalytical and Nuclear chemistry, 162, 239-251.

Lee, Y.; Um, I.H.; Yoon, J. (2003) Arsenic(III) Oxidation by Iron(VI) (Ferrate) and Subsequent Removal of Arsenic(V) by Iron(III) Coagulation. Environmental Science \& Technology, 37, 5750-5756.

Landon, S.; Donahue, C.; Jeyanayagam, S.; Cruden, D. (2006) Rain check. Water Environment \& Technology, 18, 30-35.

Lee, Y.; Zimmermann, S. G.; Kieu, A. T.; Von Gunten, U. (2009) Ferrate (Fe (VI)) Application for Municipal Wastewater Treatment: A Novel Process for Simultaneous 
Micropollutant Oxidation and Phosphate Removal. Environmental Science \& Technology, 43, 3831-3838.

Lim, M.; Kim, M. J. (2010) Effectiveness of Potassium Ferrate $\left(\mathrm{K}_{2} \mathrm{FeO}_{4}\right)$ for Simultaneous Removal of Heavy Metals and Natural Organic Matters from River Water. Water Air and Soil Pollution, 211, 313-322.

Metcalf \& Eddy, Inc. (2003) Wastewater Engineering: Treatment and Reuse, 4th ed.; Mc Graw-Hill: New York.

McHale, K. (2011) Phosphorous removal using ballasted flocculation. In $18^{\text {th }}$ Annual AWEA Speciality Conference, Morrilton, Arkansas, September 12-13.

Mouri, G.; Takizawa, S.; Fukushi, K.; Oki, T. (2013) Estimation of the Effects of Chemically-Enhanced Treatment of Urban Sewage System Based on Life-cycle Management. Sustainable Cities and Society.

Plum, V.; Dahl, C. P.; Bentsen, L.; Petersen, C. R.; Napstjert, L.; Thomsen, N. B. (1998) The Actiflo Method. Water Science and Technology, 37, 269-275.

Perkowski, J.; Kos, L. (2002) Treatment of Textile Dyeing Wastewater by Hydrogen Peroxide and Ferrous Ions. Fibres and Textiles in Eastern Europe, 10, 78-81.

Pratt, C.; Parece, T.; King, K.; Jenkins, T.; Amirhor, P.; Hart, C. (2008) Phosphorous Removal Technologies in Tertiary Treatment. NEWEA Annual Conference; Boston, Massachusetts. 
Remsberg, J. R.; Rice, C. P.; Kim, H.; Arikan, O.; Moon, C. (2008) Removal of Estrogenic Compounds in Dairy Waste Lagoons by Ferrate (VI). In ACS symposium series; Oxford University Press. pp. 420-433.

Sharma, V.; Kazama, F.; Jiangyong, H.; Ray, A. (2005) Ferrates (Iron (VI) and Iron (V)): Environmentally Friendly Oxidants and Disinfectants. Journal of Water Health, 3, 45-58.

Sharma, V. K.; Mishra, S. K. (2006) Ferrate (VI) Oxidation of Ibuprofen: A Kinetic Study. Environmental Chemistry Letters, 3, 182-185.

Stanford, C.; Jiang, J. Q.; Alsheyab, M. (2010) Electrochemical Production of Ferrate (Iron VI): Application to the Wastewater Treatment on a Laboratory Scale and Comparison with Iron (III) Coagulant. Water, Air, \& Soil Pollution, 209, 483-488.

Sharma, V. K.; Sohn, M.; Anquandah, G. A.; Nesnas, N. (2012) Kinetics of the Oxidation of Sucralose and Related Carbohydrates by Ferrate (VI). Chemosphere, 87, 644-648.

Tiwari, D.; Yang, J.; Lee, S. (2005) Applications of Ferrate (VI) in the Treatment of Wastewaters. Environmental Engineering Research, 10, 269-282.

US Environmental Protection Agency (1999a) Combined Sewer Overflow Management Fact Sheet: Sewer Separation; EPA 832-F-99-041; Washington, D.C.

US Environmental Protection Agency (1999b) Combined Sewer Overflow Technology Fact Sheet: Retention Basins; EPA 832-F-99-042; Washington, D.C.

US Environmental Protection Agency (2001) Report to Congress: Implementation and Enforcement of the CSO Control Policy; EPA 833-R-01-003; Washington, DC. 
US Environmental Protection Agency (2003) Wastewater Technology Fact Sheet: Ballasted Flocculation; EPA 832-F-03-010; Washington, D.C.

US Environmental Protection Agency (2008) Emerging Technologies for Wastewater Treatment and In Plant Wet Weather Management; EPA 832-R-06-006; Fairfax, Virginia.

US Environmental Protection Agency (2013) Emerging Technologies for Wastewater Treatment and In Plant Wet Weather Management; EPA 832-R-12-011; Fairfax, Virginia.

White, D. A.; Franklin, G. S. (1998) A Preliminary Investigation into the Use of Sodium Ferrate in Water Treatment. Environmental Technology, 19, 1157-1161.

Zukovs, G., and Marsalek, J. (2004) Planning and Design of Combined Sewer Overflow Treatment. Water Quality Research Journal of Canada, 39, 439-448. 


\section{Chapter 2}

\section{Literature Review}

\subsection{Combined sewer overflows (CSOs)}

Collection of domestic sewage, industrial wastewater and rainwater runoff in a single pipe is termed as combined sewer system (Metcalf and Eddy, 2003). The concept of using combined sewer systems was initiated in Europe in 1840's (Field et al., 2003). North America incorporated this concept in late $19^{\text {th }}$ century. Climate changes affect the collection and functionality of these systems (EPA, 2008a). During rainy seasons, combined sewer systems experience an increase in volume of flowing wastewater. Depending on the capacity, some of the combined sewer systems cannot handle the excess wastewater volume due to rainwater runoff. In order to prevent flooding and sewer backups due to the exceeding volume, some of this wastewater is diverted to the overflow pipe and is then discharged into nearby lakes, rivers and oceans. This discharge from combined sewer systems is termed as combined sewer overflows (CSOs) (Zukovs and Marsalek, 2004). 


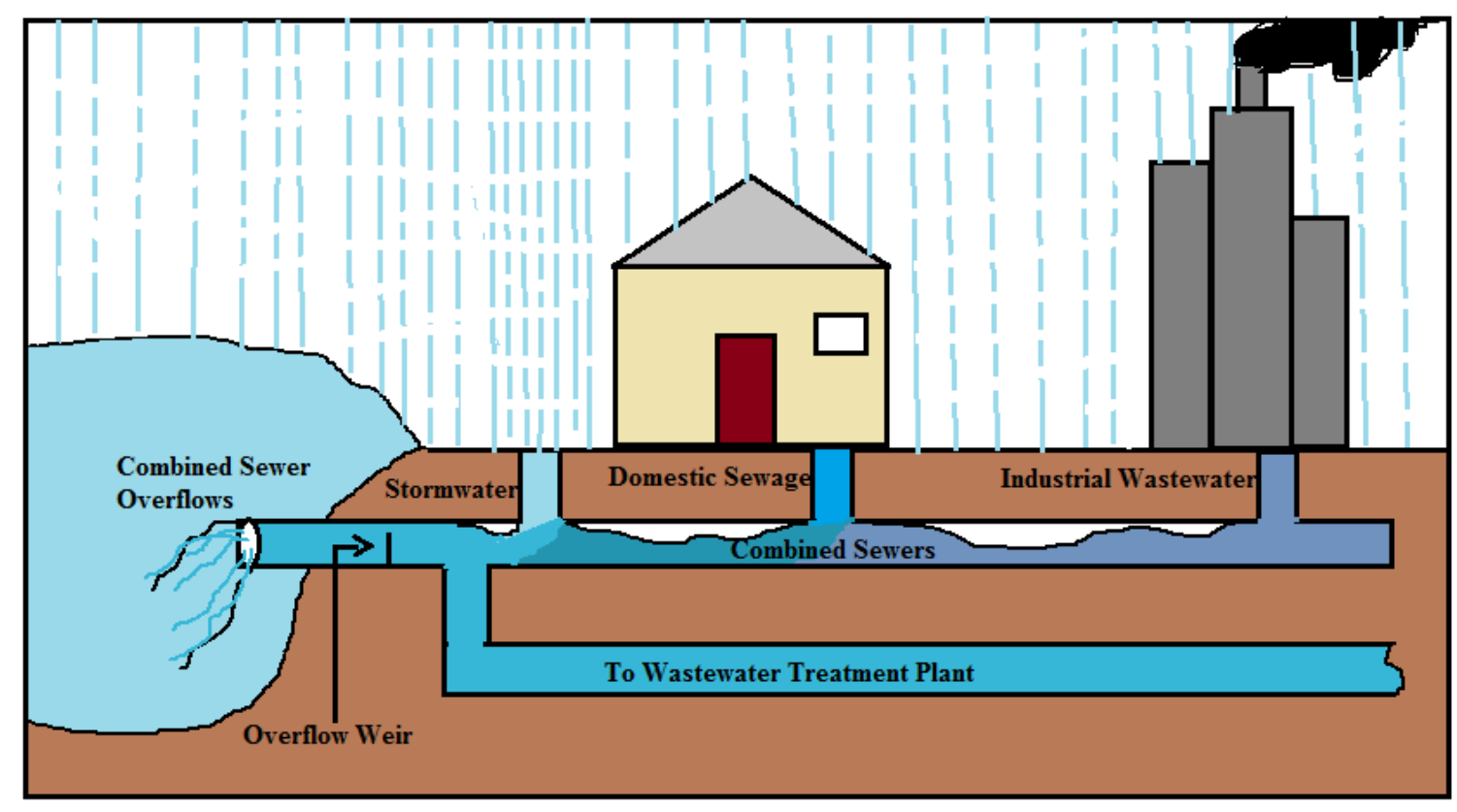

Figure 2.1: Combined Sewer Overflows

\subsubsection{Impacts of CSOs}

The CSOs are directly discharged into river streams, lakes or oceans. Wastewater carries number of bacteria and viruses which are harmful to the human environment (Metcalf and Eddy, 2003). Storm water before getting into the combined sewer collects chemicals, pesticides, oils and other wastes from the roadsides, parking lots, fields (EPA, 1994). Introduction of overflow to the receiving water disturbs the aquatic environment and also possess threat for human beings. CSOs act as a shock loading to environmental and biological surrounding. Table 2.1 (EPA 2001) summarizes pollutants and principal consequences of CSOs. 
Table 2.1: Pollutants and their principal consequences (EPA 2001)

\begin{tabular}{|c|c|}
\hline Pollutants & Principal Consequences \\
\hline $\begin{array}{l}\text { Bacteria } \\
\text { Viruses } \\
\text { Protozoa }\end{array}$ & $\begin{array}{l}\text { Beach closures } \\
\text { Shellfish bed closures } \\
\text { Drinking water contamination } \\
\text { Adverse public health effects }\end{array}$ \\
\hline Trash and floatables & $\begin{array}{l}\text { Aesthetic impairment } \\
\text { Devaluation of property } \\
\text { Odors } \\
\text { Beach closures } \\
\end{array}$ \\
\hline $\begin{array}{l}\text { Organic compounds } \\
\text { Metals } \\
\text { Oil and grease } \\
\text { Toxic pollutants } \\
\end{array}$ & $\begin{array}{l}\text { Aquatic life impairment } \\
\text { Adverse public health effects } \\
\text { Fishing and shell fishing restrictions }\end{array}$ \\
\hline $\begin{array}{l}\text { Biochemical oxygen demand } \\
\text { (BOD } 5 \text { ) }\end{array}$ & Reduced oxygen levels and fish kills \\
\hline Solids deposits (sediments) & $\begin{array}{l}\text { Aquatic habitat impairment } \\
\text { Shellfish bed closures }\end{array}$ \\
\hline Nutrients & $\begin{array}{l}\text { Eutrophication, algal blooms } \\
\text { Aesthetic impairment }\end{array}$ \\
\hline Flow shear stress & Stream erosion \\
\hline
\end{tabular}

\subsubsection{Factors affecting the concentrations of pollutants in CSOs}

The concentrations of pollutants depend on the quality of domestic wastewater, industrial wastewater and stream water runoff entering the combined sewer system. During rainfall or snowmelt event, perturbation occurs in the combined sewer system; settled particles get re-suspended into the flowing stream resulting into what is known as "first flush effect". Pollutants concentrations are high during first flush effect. The first flush effect 
can be observed for half an hour or more during heavy rainfall (EPA, 2004). The duration and the intensity of wet weather event also affect the concentrations of pollutants in CSOs (EPA, 2004).

Sierra legal report (2006) published that, from 20 cities examined, around 92 billion liters of raw sewage mixed with storm water was released into great lakes (which include Lake Superior, Lake Michigan, Lake Huron, Lake Erie and Lake Ontario) in one year via CSOs.

\subsection{Regulations governing discharge of CSOs}

US Environmental Protection Agency (EPA) and Ontario Ministry of the Environment (MOE), sets up different treatment standards for different sewage treatment plants (Sierra legal report, 2006). According to Ministry of Environment (MOE) regulations for bypass treatment mentioned in procedure F-5-5, the removal efficiency of five day biochemical oxygen demand $\left(\mathrm{BOD}_{5}\right)$ and total suspended solids (TSS) should be $30 \%$ and $50 \%$ respectively. According to the US EPA, CSO related bypass flows must receive primary clarification, solids and floatables removal and disinfection.

\subsubsection{Laws}

Water management issues related laws can be passed by both federal and provincial governments, according to Canada's Constitution Act. Canadian Environmental Protection Act 1999 (CEPA) and the Fisheries Act are monitored by Environment Canada under Canadian Federal Laws. Toxic substances and Nutrients are regulated by CEPA. Fish habitat protection comes under Fisheries Act. Ontario Water Resources Act 
(OWRA) and Environmental Protection Act (EPA) are governed by Ontario ministry under Ontario law. Ontario Ministry of Environment monitors the sources of water pollution through OWRA (Sierra legal report, 2006).

\subsubsection{CSO Control Policy (EPA, 1994)}

Following are the key points of CSO control policy which makes sure that all the objectives of clean water act are fulfilled and the controls are cost effective

1. Clear levels of control needed to meet health and environmental criteria should be provided.

2. Municipalities should be given sufficient amount of freedom in order to come out with economic ways of abatement of pollutants caused due to CSO discharge and to satisfy all clean water act requirements.

3. Depending on the monetary capacity of municipalities, distributive approach should be given a green signal during the CSO controls implementation.

4. Provision should be made to review water quality standards and different issues surrounding it during the execution of CSO control plan.

In order to facilitate the implementation of CSO control policy EPA have published nine minimum controls (NMC) which can be helpful in responding to the CSO problems with very less construction costs and minimal engineering analysis. NMC forms the base to the implementation of long term control plan (LTCP).

Following are the nine minimum controls: (EPA, 2004) 
1. There must be a smooth operation and regular checkup of the collection systems. If collection system failure happens there can be a high risk of pollution, thus maintenance is a major preventative step in order to ensure the proper working of collection systems.

2. There should be an ultimate use of the storage tanks.

High usage of storage tanks can prevent higher discharge of untreated wastewater into the receiving stream thus helping in reducing the contamination.

3. Pretreatment programs should undergo a strict revisions and necessary changes.

4. Wastewater treatment plants capacity should be fully utilized.

All the WWTP's are designed in such a way that they can handle flows higher than their design capacities (peaking factor generally is 3 ). This can reduce a CSO discharge.

5. Care should be taken in order to avoid CSO discharge during no rainfall period (Dry weather period).

6. Preventive measures should be taken in order to reduce or monitor solid and floatable substances in CSO discharge.

7. Various programs should be established which can directly or indirectly help in pollution control.

8. Public should be made aware of the CSO, its impacts and danger related to it.

9. Monitoring should be done to characterize the CSO impacts and the efficiency of CSO controls.

In July 2004, EPA reported that for 94 percent of the active CSO permits, NMC execution was required. NMC made a base for the design of the long term control plan 
(LTCP). LTCP included more detailed implementation. It included various aspects such as public participation, economic considerations, alternative techniques to control CSO, management plans, modeling and monitoring CSO discharge, increasing the treatment capacity of WWTP and post construction checkup. In Canada, the Federal laws have no obligations on CSO's until they meet all the requirements under Fisheries Act. Ontario Procedure F-5-5 lists following CSO control requirements: (Sierra legal report, 2006)

1. There should be no overflows during dry season unless and until there is major system failure.

2. There must be a smooth operation and regular maintenance of the systems.

3. Various programs regarding pollution control or prevention should be initiated.

4. Floatables in the combined sewer systems should be controlled.

5. There should be maximum storage of wastewater in tanks during heavy rainfalls.

6. Treatment plant utilization should be maximized during rain events.

\subsection{CSO treatment techniques}

The simplest way to get rid of the Combined Sewer Overflow (CSO) crisis is to separate the sewers (EPA 1999a).This is not an economically viable option. Various treatment techniques are being used to treat CSOs.

\subsubsection{Wetlands}

Wetlands are shallow aquatic bodies which act as a filter for treatment of wastewater. Wetlands are also called as soil retention filters. Aquatic vegetation grown on these wetlands makes them retain permeability (Atlantic agriculture, 2005). Wetlands can be 
used for primary treatment of CSOs. There are few ways in which wetland treatment technique can be applied:

1. CSOs can directly pass through the wetlands framework and then into receiving water.

2. CSOs can first be stored in storage tank. The outlet of the storage tank can be directly run into wetlands and then into receiving streams.

3. Wetlands can also be constructed in such a way that domestic wastewater, Industrial wastewater and storm water can directly be allowed to pass through them before getting into combined sewer systems. This can act as a pretreatment for wastewater plants.

In the wetland treatment technique, inlet wastewater source is situated above the constructed wetlands. Wetlands are made up of fine sand usually of diameter ranging from 0-2 mm (Uhl et al., 2005). This sand is covered with water which grows aquatic vegetation which helps in retaining permeability. The longer roots of these vegetation helps in producing oxygen at the bottom surface near soil layer, developing an environment favorable for aerobic bacteria. These bacteria help in degrading organic material from the influent stream. Suspended solids can be removed by the soil filter when waste water passes through the soil medium. The typical soil permeability for Free water surface constructed wetlands is $10^{-6}-10^{-7} \mathrm{~m} / \mathrm{s}$ (EPA, 1988). Nutrient removals can be achieved by adding carbon and ferric source to filter medium (Uhl et al., 2005). Meyer et al. (2013) reported the design criteria of constructed wetlands (CW) in France and Italy for CSO treatment. Table 2.2 represents the design criteria. 
Table 2.2: Design criteria of constructed wetlands (CW) in France and Italy (Meyer et al., 2013)

\begin{tabular}{|c|c|c|}
\hline Criteria & $\begin{array}{c}\text { CW France } \\
\text { (full-scale Marcy-l'Etoile) }\end{array}$ & $\begin{array}{c}\text { CW Italy } \\
\text { (full-scale Gorla Maggiore) }\end{array}$ \\
\hline Filter Bed & $\begin{array}{l}2 \text { alternated loaded, } \\
\text { in Parallel for extreme } \\
\text { events }\end{array}$ & $\begin{array}{l}4 \text { alternated loaded, } \\
\text { in parallel for extreme events }\end{array}$ \\
\hline $\begin{array}{c}\text { Retention Layer } \\
\text { Depth }\end{array}$ & $\begin{array}{c}\text { Flexible }(0.1,0.35,0.6 \text { or } \\
0.8 \mathrm{~m} \\
\text { each bed }), \\
2 \mathrm{~m} \text { for connected beds }\end{array}$ & minimum $0.2 \mathrm{~m}$ \\
\hline Filtration Layer & $\begin{array}{c}\text { Minimum } 0.5 \text { m (one bed } \\
\text { sand + } \\
\text { zeolite, one bed pozzolana) }\end{array}$ & $\begin{array}{c}0.2 \mathrm{~m}(\text { gravel } 10 \mathrm{~mm}) \\
+0.4 \mathrm{~m}(\text { gravel } 2 / 6 \mathrm{~mm})\end{array}$ \\
\hline Saturated Layer & $\begin{array}{c}\text { flexible, minimum } 0.2 \mathrm{~m} \\
(0.3 \mathrm{mgravel} 10 / 20 \mathrm{~mm}, \\
0.1 \mathrm{~m} \text { gravel } 3 / 8 \mathrm{~mm})\end{array}$ & $0.2 \mathrm{~m}$ (gravel 40/80 mm) \\
\hline Outflow Limitation & $0.02 \mathrm{~L} /\left(\mathrm{m}^{2} . \mathrm{s}\right)$ & $0.004 \mathrm{~L} / \mathrm{m}^{2} . \mathrm{s}$ \\
\hline $\begin{array}{l}\text { Max. hydraulic } \\
\text { loads }\end{array}$ & $40-80 \mathrm{~m}^{3} / \mathrm{m}^{2}$ per year & $\begin{array}{c}35-40 \mathrm{~m}^{3} / \mathrm{m}^{2} \text { in annual } \\
\text { average } \\
\text { (max. } 50 \mathrm{~m}^{3} / \mathrm{m}^{2} \text { per year) }\end{array}$ \\
\hline
\end{tabular}

The CW treatment performance for the combined sewer system in North America reported by Kadlec and Knight (1996) are mentioned in Table 2.3.

Table 2.3: North American Treatment operational performance (Kadlec and Knight, 1996)

\begin{tabular}{|c||c||c||c||}
\hline Parameter & $\begin{array}{c}\text { Inlet Conc. } \\
(\mathbf{m g} / \mathbf{l})\end{array}$ & $\begin{array}{c}\text { Outlet Conc. } \\
(\mathbf{m g} / \mathbf{l})\end{array}$ & Removal \\
\hline \hline BOD $_{5}$ & 30.3 & 8 & 74 \\
\hline TSS & 45.6 & 13.5 & 70 \\
\hline TP & 3.78 & 1.62 & 57 \\
\hline
\end{tabular}


The use of wetlands for treatment of CSOs carry numerous advantages such as, it is cost effective, have low maintenance, require short startup time and creates an aesthetic environment for birds and aquatic habitat. Treatment of CSOs using wetlands have its own disadvantages, for example, it requires larger area, cannot sustain longer dry weather periods, clogging can take place resulting in the reduction of removal efficiencies in long run and more importantly it cannot remove soluble organics.

\subsubsection{Settling tanks}

Additional settling tank just before the wastewater treatment plant can have multiple benefits (Kerbs et al. 1999). During the wet weather event, excess water from the combined sewer system can be stored in the settling tanks and when the wet weather flow decreases the stored wastewater can then pass into the WWTP. Thus settling tank can act as a storage tank and is also termed as retention time basin (Zukovs and Marsalek, 2004). In normal day to day activity it can act as a pretreatment settling tank in which suspended solids due to controlled flow and residence time can settle in the settling tank. Addition of coagulants to the tank and introducing stirring mechanisms can increase the settling of suspended solids and removal of various bacteria (EPA 1999b). The storage volume of retention basin is generally calculated using flow route modeling. The basin or tank shape generally should be circular or octagonal as they can be upgraded easily to self-clean settled solids and should have low inflow in order to avoid re suspension of settled solids. Brombach et al. (2008) specified the design criteria for retention basin in Germany for treatment of CSOs. These design criteria are noted in Table 2.4. 
Table 2.4: Design criteria for retention basin (RB) in Germany (Brombach et al., 2008)

\begin{tabular}{|l||l||}
\hline Parameter & Value \\
\hline $\begin{array}{l}\text { Surface Overflow rate } \\
\text { (SOR) }\end{array}$ & $>10 \mathrm{~m} / \mathrm{h}$ \\
\hline \multirow{3}{*}{ Inflow, critical } & $\begin{array}{l}(15 \mathrm{~L} /(\text { s.ha }))^{*} \text { impervious catchment area. } \\
\text { For ecology sensitive receiving waters, } \\
(30 \mathrm{~L} /(\mathrm{s} . \mathrm{ha}))^{*} \text { impervious catchment area }\end{array}$ \\
\hline \hline Sedimentation chamber & $\begin{array}{l}\text { Long and Narrow } \\
10<\mathrm{L} / \mathrm{H}<15,3<\mathrm{L} / \mathrm{W}<4.5, \\
2<\mathrm{W} / \mathrm{H}<4\end{array}$ \\
\hline \hline Horizontal Flow Velocity & $<5 \mathrm{~cm} / \mathrm{s}$ \\
\hline \hline Clarifier Overflow & $<75 \mathrm{~L} / \mathrm{s} . \mathrm{m}$ \\
\hline \hline & within $10-15$ hours, to avoid odor and \\
Emptying CSO tank & fouling \\
\hline \hline
\end{tabular}

The $90 \%$ reduction in the CSO discharge volume was noticed after the construction of 30 MG retention basin at Grand Rapids (EPA, 1999b). The well designed settling tank typically achieves the removal of TSS and $\mathrm{BOD}_{5}$ in the range of $50-70 \%$ and $25-40 \%$ respectively (Metcalf and Eddy, 2003).

The settling tanks can survive long period without feed water and has low maintenance. With these positives, settling tanks have few drawbacks such as it requires high construction cost and moreover during the wet weather events, settling tanks can also overflow, leading to the discharge of untreated CSOs into the water streams.

\subsubsection{Chemically Enhanced Primary Treatment (CEPT)}

Chemically Enhanced Primary Treatment (CEPT) is a process in which coagulants and flocculants are introduced into the untreated CSOs to enhance the removal of the pollutants (Haydar and Aziz, 2009; Chagnon and Harleman, 2004). Ferric chloride and 
poly aluminium chloride are the most commonly used coagulants in CEPT (Harleman and Murcott, 1992). The introduction of coagulants into the CSOs destabilizes the charge on the suspended and colloidal particles thus speeding up the process of coalescence. The particles cling to each other forming larger particulate or flocs thus increasing the settling velocity, resulting into higher removal efficiencies (McLean, 2009). Figure 2.2 represents the schematic diagram of CEPT. In general, CEPT can handle surface overflow rates (SOR) of 10-30 gpm/sf. Typical removal efficiencies of TSS and $\mathrm{BOD}_{5}$ achieved by CEPT are in the range of 70-90\% and 35-50\% respectively (McLean, 2009).

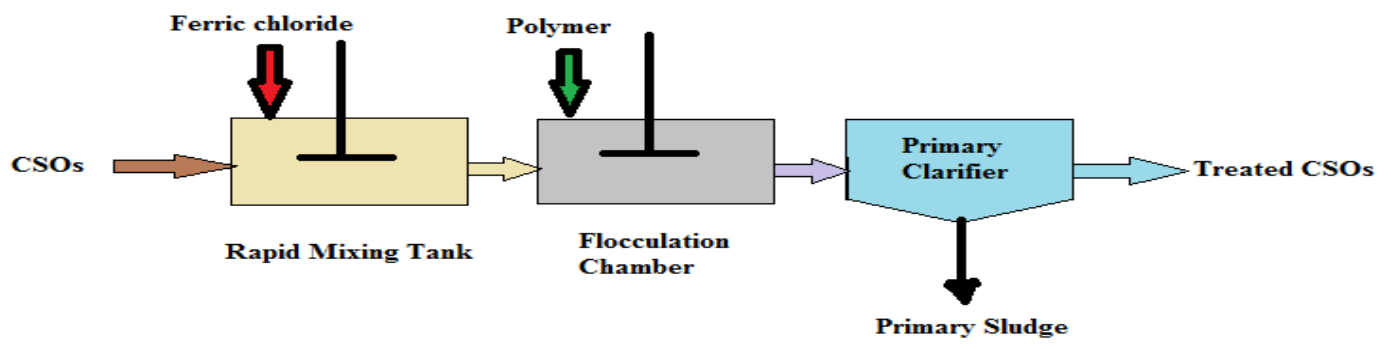

Figure 2.2: Schematic Diagram of Chemically Enhanced Primary Treatment

Morrissey and Harleman (1992) reported that, CEPT process set up at Point Loma, San Diego, for SOR of $4.5 \mathrm{~m} / \mathrm{h}$ yielded $85 \%$ TSS removal, $55 \% \mathrm{BOD}_{5}$ removal and $85 \%$ phosphorous removal. The ferric chloride dose of $25 \mathrm{mg} / \mathrm{l}$ and polymer dose of $0.2 \mathrm{mg} / \mathrm{l}$ were used. The CEPT process located at Ipiranga WWTP, Sao Paulo, Brazil observed $62 \%, 58 \%, 80 \%$ removal of $\mathrm{COD}, \mathrm{BOD}_{5}$ and TSS respectively for the flow rate of $50 \mathrm{~L} / \mathrm{s}$ and the chemical doses of $50 \mathrm{mg} / \mathrm{l}$ ferric chloride and $0.5 \mathrm{mg} / 1$ soluble polymer (Bourke Jr., 2000). The high retention time, high amount of coagulant doses, large quantity of sludge, the incapability of the removal of soluble organic materials and high operational 
and maintenance cost (Bourke Jr., 2000) are the few drawbacks of CEPT technique (Morrissey and Harleman, 1992).

\subsubsection{High rate ballasted clarification treatment}

\subsubsection{Actiflo}

Actiflo (USFilter, Kruger Products, Cary, North Carolina) is a high rate ballasted clarification treatment process, a combination of coagulation, weighted flocculation and Lamella settling (Plum et al., 1998; Landon et al., 2006; Blumenschein et al., 2006). A coagulant, typically ferric chloride or poly-aluminium chloride is added to untreated CSO before entering the coagulation tank (see Figure 2.3). The flow enters the coagulation tank where suspended solids are destabilized and then overflows into the injection tank where polymer and microsand, a ballast material is added. The flow enters the maturation stage where flocculation takes place with the help of gentle mixing. The microsand serves as a seed for the floc formation. The ballasted floc then enters the settling tank in which floc settle due to gravity in the cone shaped chamber. The settling is enhanced by inclined tube settlers. The sludge scraper removes high volume of sludge. The microsand containing sludge is directed to a hydrocyclone which separates microsand from sludge and reintroduces microsand back into the injection tank (Frank and Smith III, 2006; Zhu et al., 2007; EPA, 2003; EPA, 2008). The typical hydraulic retention time (HRT) for coagulation tank, injection tank and maturatin tank is 2,2 and 8 minutes respectively (Blumenschein et al., 2006). The microsand particles used are in general 45-150 microns in diameter (EPA, 2003) and have a specific gravity of 2.65 (Blumenschein et al., 2006; 
Metcalf and Eddy, 2003). The Actiflo system can handle the overflow rate in the range of 40-60 gpm/sf (EPA, 2003; Blumenschein et al., 2006).

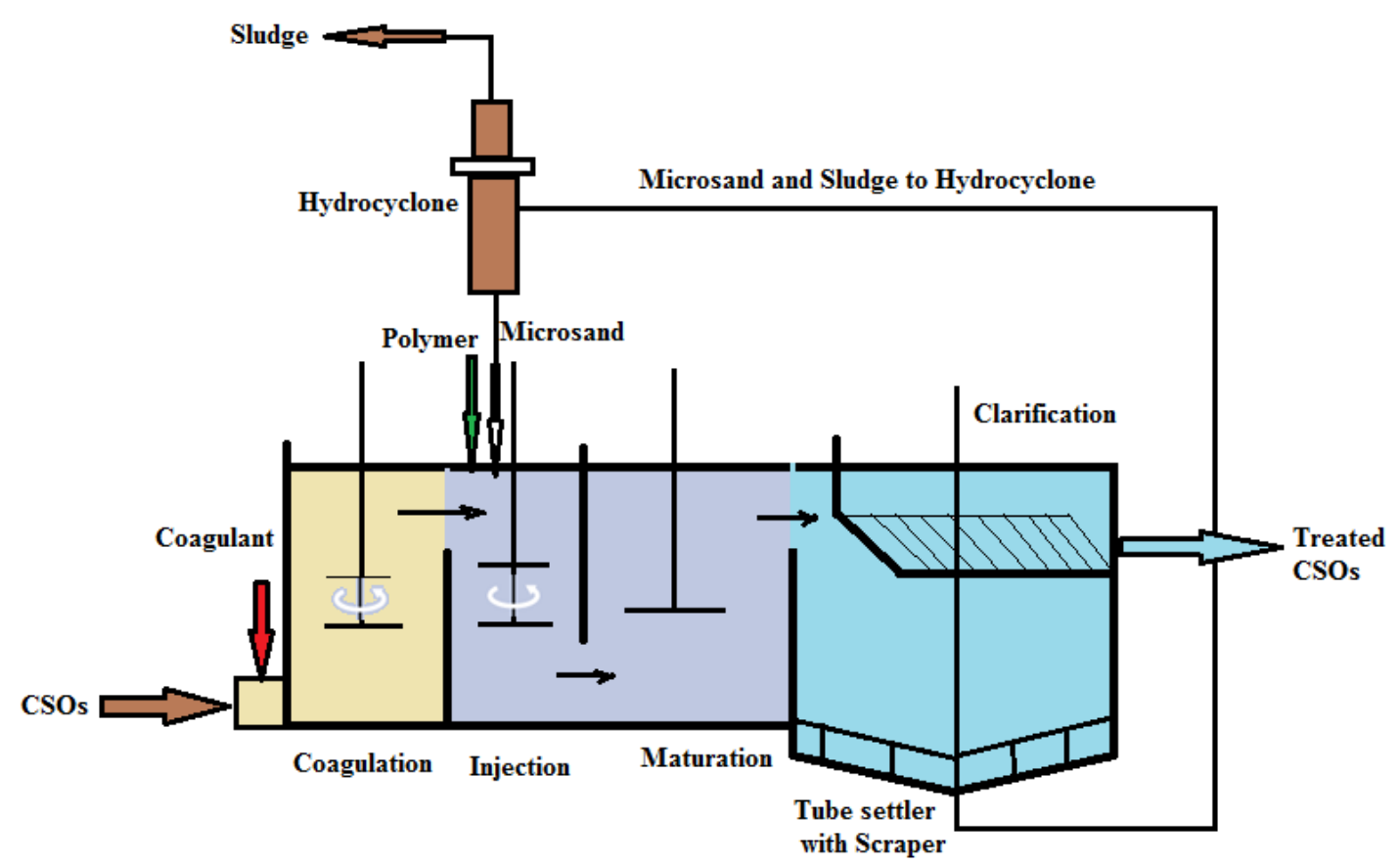

Figure 2.3: Actiflo Process Diagram (EPA, 2008)

A pilot Actiflo plant was set up at the Airport Wastewater Treatment Plant in Galveston, Texas to evaluate the performance. The TSS, COD and $\mathrm{BOD}_{5}$ removal for the $150 \mathrm{~m} 3 / \mathrm{h}$ CSOs were reported to be in the range of $80-94 \%, 65-83 \%$ and $48-75 \%$ respectively with the retention time of 7 minutes and startup time of 30 min (EPA, 2003). Ponist and Scheiter (2006) reported the HRT of $15 \mathrm{~min}$ and average removal of $88 \%$ TSS by the 12 MGD Ballasted High Rate Clarification Process set up in the City of Greenfield Indiana. A study was conducted by Jolis and Ahmad (2004) on the pilot Actiflo plant having an hydraulic capacity of $32.8 \mathrm{~L} / \mathrm{s}$, located at the Southeast Water Pollution Control Plant (SEWPCP) in San Francisco, California. The removal efficiency of 70-80\% and 50-65\% 
of TSS and $\mathrm{BOD}_{5}$ respectively and hydraulic retention time of 13 min was reported. The $\mathrm{FeCl}_{3}$ dose of $80 \mathrm{mg} / \mathrm{l}$ and polymer dose of $1 \mathrm{mg} / \mathrm{l}$ was required. US Filter Actiflo demonstration facility at the West Point Wastewater Treatment Plant, Seattle, Washington, achieved 93-94\% TSS removal, 60-71\% COD removal and 75-91\% TP removal at the surface overflow rate of $53.4 \mathrm{gpm} / \mathrm{sf}$ and for polymer and alum dose of $0.85 \mathrm{mg} / \mathrm{l}$ and $60 \mathrm{mg} / \mathrm{l}$ respectively. The total hydraulic retention time, dry startup time and wet start up time were reported as 6.5, 15 and 10 min respectively (Leng et al., 2002). Plum et al (1998) reported that the Actiflo method does not remove dissolved organic matter and nitrogen. The high startup time is the main disadvantage of the Actiflo system (EPA, 2003).

\subsubsection{DensaDeg}

The DensaDeg (Infilco Degremont, Inc., Richmond, Virginia) is a physical-chemical process made up of three units; coagulation, flocculation and clarification unit. The DensaDeg process works on the same principle as Actiflo, using thickened recirculated sludge as ballast material instead of microsand. The coagulant is added to the incoming CSO water in the coagulation unit, where it is rapidly mixed. This coagulated stream then enters the flocculation unit and is combined with the recirculated thickened sludge obtained from the clarification unit. The polymer addition is also done in this stage (see Figure 2.4). The flocculation unit comprises of turbine which promotes mixing and contact between the solids and recycled sludge forming denser flocs. This flocculated stream enters the clarification unit where solids settle out and sludge is thickened before getting recycled back to the flocculation unit. The treated water exits the system from the 
top with the help of lamella tube assembly (EPA 2008; Jolis and Ahmad, 2004; Landon et al., 2006).

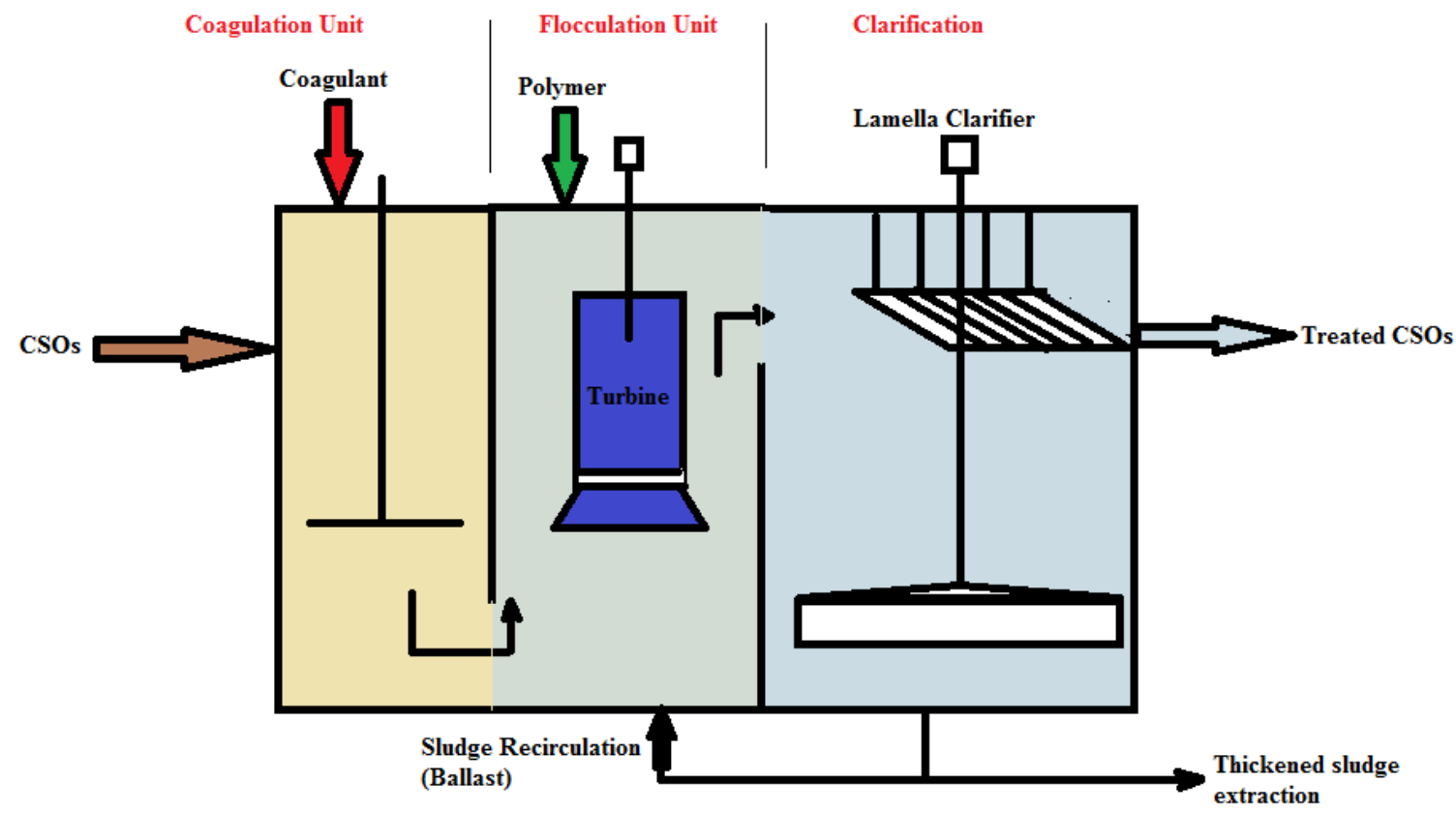

Figure 2.4: Schematic representation of DensaDeg process (EPA, 2008)

Densadeg 4D system set up at Village Creek WWTP Birmingham, Alabama achieved 45$60 \%$ and $80-95 \%$ removal of COD and TSS respectively with the HRT of 15 min (EPA, 2003). The DensaDeg system handling the SOR of $40 \mathrm{gpm} / \mathrm{sf}$ piloted at the Water Pollution Control Station (WPCS) at the City of Akron, Ohio removed $83 \%$ TSS and $55 \% \mathrm{BOD}_{5}$ using $85 \mathrm{mg} / \mathrm{l}$ ferric chloride and $0.77 \mathrm{mg} / 1$ polymer dose (Frank and Smith III, 2006). The pilot DensaDeg plant set up at city of Fort Worth, Texas, handling the SOR of $40-60 \mathrm{gpm} / \mathrm{sf}$ achieved $\mathrm{BOD}_{5}$ removal in the range of $37-63 \%$, TSS removal in the range of $81-90 \%$ and TP removal in the range of $88-95 \%$ when the ferric chloride and polymer doses used were in the range of $70-125 \mathrm{mg} / \mathrm{l}$ and $0.75-1 \mathrm{mg} / \mathrm{l}$ respectively. The 
HRT observed was in the range of 15-22 min (EPA 2003; Sawey et al., 1999). Landon et al. (2006) pilot tested the DensaDeg system situated at Southerly Wastewater Treatment Plant. The system with the surface overflow rate of $40 \mathrm{gpm} / \mathrm{sf}$ achieved $85 \%$ TSS removal with the use of $70 \mathrm{mg} / \mathrm{l}$ ferric chloride and $2.5 \mathrm{mg} / \mathrm{l}$ polymer dose. The hydraulic retention time observed was 14 min. Removal of soluble organics using DensaDeg process has never been reported. The high doses of metal salt required, the high startup time and the amount of sludge produced are the main disadvantages of the high rate clarification processes (EPA, 2003; Jolis and Ahmad, 2004).

\subsubsection{CoMag}

CoMag (Siemens, inc., Alpharetta, Georgia) is a high rate ballasted sedimentation process for enhanced removal of phosphorous (generally from secondary effluent) and suspended solids (EPA 2008). The CoMag technology is a combination of chemical coagulation and weighted flocculation with magnetite as ballast. Typical CoMag process is shown in Figure 2.5. The coagulant added to the influent CSOs get dispersed by mechanical mixing thus destabilizing the colloidal particles. The addition of polymer aggregates the particle forming the flocs. Magnetite has a specific gravity of 5.2 which helps in formation of denser flocs resulting in faster settling (Backman and Irwin, 2012; McHale, 2011). The magnetite is recovered from the sludge by magnetic drum and is reintroduced into mixing tank. 


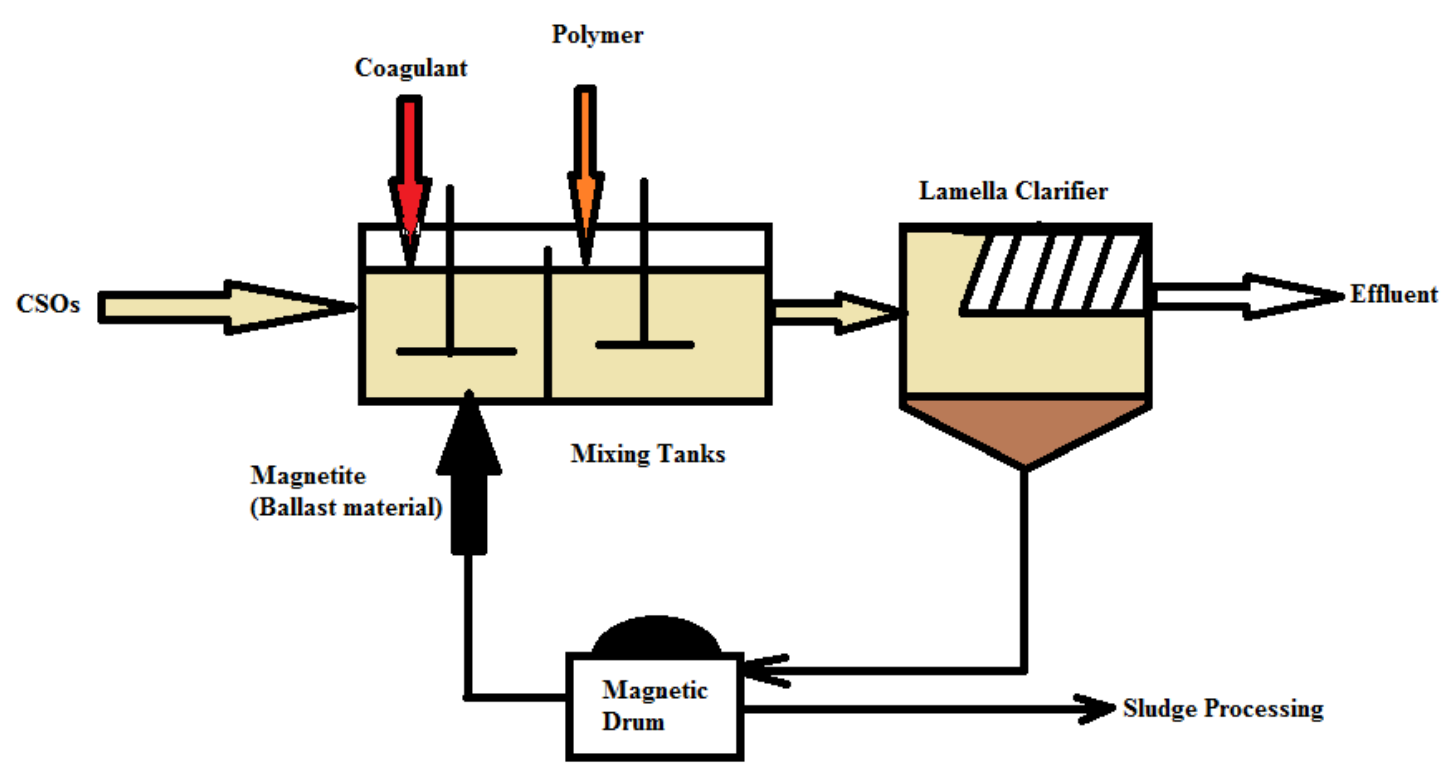

Figure 2.5: CoMag Process (Backman and Irwin, 2012)

The CoMag system is flexible to wide ranges of flows. It requires low maintenance and has rapid start up time typically 15 min (Dittami, 2008). CoMag plant can handle CSO surface overflow rate upto $50 \mathrm{gpm} / \mathrm{sf}$. The typical removal efficiencies of TSS, $\mathrm{BOD}_{5}$ and TP achieved are greater than $90 \%, 50 \%$ and $95 \%$ respectively. Typical HRT is 5-15 min depending on plant capacity (Backman and Irwin, 2012; McHale, 2011). The pilot CoMag plant setup at Westborough WWTP for tertiary treatment achieved 45\% and 75\% removal of $\mathrm{BOD}_{5}$ and TSS respectively for the $30 \mathrm{mg} / \mathrm{l}$ and $3 \mathrm{mg} / \mathrm{l}$ ferric chloride and polymer dose, respectively (Pratt et al., 2008; Hardy, 2008). CoMag is an emerging Technology and has no full scale installations for CSO treatment yet (EPA, 2013). Backman and Irwin (2012) reported that CoMag can be used only for the removal of particulate contaminants. 


\subsection{Ferrate (VI)}

The most common oxidation states of iron that exists are +2 and +3 . Iron being a transition metal, higher oxidation states such as $+4,+5$ and +6 can also be obtained (Sharma et al., 2005). All the oxidation states of iron above +3 are generally termed as Ferrate out of which $\mathrm{Fe}(\mathrm{VI})$ is well known because of its stability with respect to +4 and +5 oxidation states and also due to its occurrence (Tiwari et al., 2005). The aqueous solution of ferrate (VI) has a reddish violet color (Jiang and Lloyd, 2002). The molecular formula of ferrate (VI) ion is $\mathrm{FeO}_{4}{ }^{2-}$ and has a tetrahedral structure (Macova et al., 2009; Jiang and Lloyd, 2002). Figure 2.6, shows the structure of ferrate (VI) in aqueous solution.

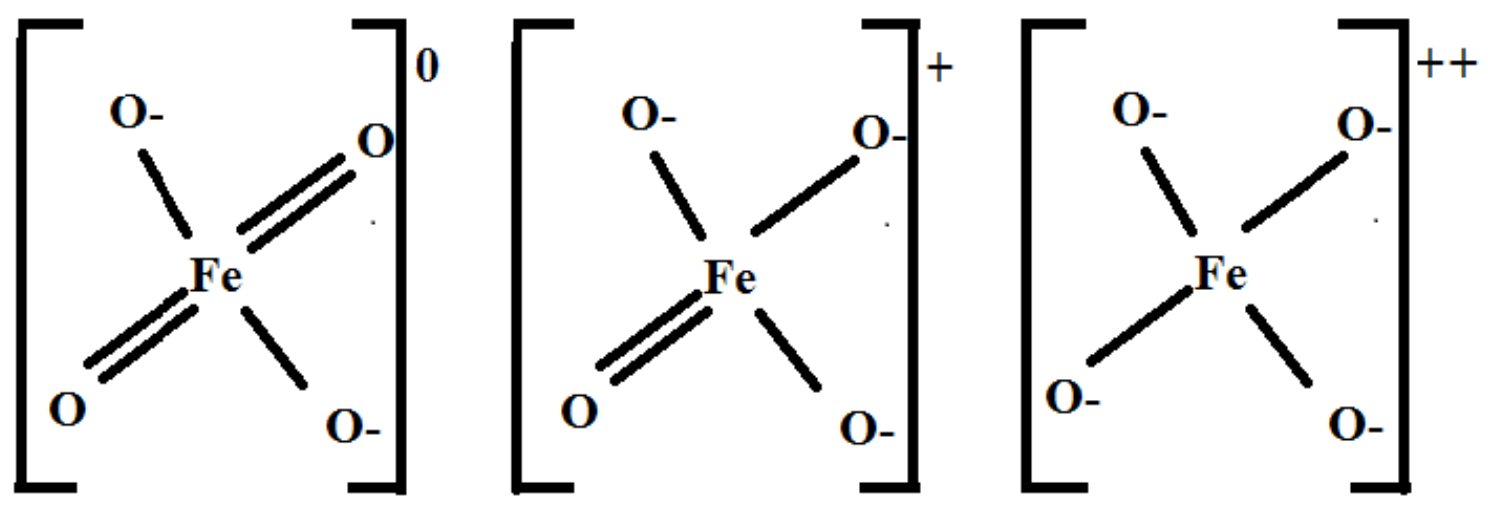

Figure 2.6: Structure of Ferrate (Norcross et al., 1997)

The redox potential of ferrate (VI) $(2.2 \mathrm{~V}$ under acidic condition and $0.72 \mathrm{~V}$ under basic condition) is greater than other oxidizing agents (Jiang et al., 2006). During the oxidation of contaminants, $\mathrm{Fe}$ (VI) gets reduced to Fe (III) ions or ferric hydroxide known for their coagulating and flocculating properties, thus providing double benefit with a single 
chemical (Jiang and Lloyd, 2002; Jiang et al., 2006; Lee et al., 2009; Sharma et al, 2005). The ferric hydroxide generated from the reduction of Fe (VI) aids the removal of metals, non-metals (Sharma, 2008). The removal of suspended particles, disinfection of microorganisms and oxidation of inorganic and organic compounds can be attained by single ferrate (VI) dose (Jiang Lloyd, 2002; Jiang et al., 2005). The colloidal particles can be destabilized within 1 min using ferrate (VI) (Jiang and Lloyd, 2002). The very low dose of ferrate (VI) can achieve greater performance as compared to the other coagulants thus reducing the sludge production (White and Franklin, 1998; Jiang et al., 2012a). There are no carcinogenic or mutagenic by products formed after the Fe (VI) treatment making it a green chemical (Sharma et al., 2005; Tiwari et al., 2005). Fe (VI) is most stable at pH 9 (Graham et al., 2004; Sharma, 2002). Potassium Ferrate is the most stable and easily prepared derivative of Fe (VI) (Sharma, 2002; Lee et al., 2004).

\subsubsection{Applications of ferrate (VI)}

Ferrate (VI) has been studied widely as a potential chemical for treatment of water and wastewater (Jiang and Lloyd, 2002; Tiwari et al., 2005). There are numerous findings reported by researchers on the $\mathrm{Fe}$ (VI) performance as an oxidant, coagulant and disinfectant in treatment of water and wastewater. Fe (VI) performance as a disinfectant in water and wastewater was thoroughly reviewed by Sharma (2007). The $6 \mathrm{mg} \mathrm{Fe}$ (VI)/l killed 99.9\% E.coli at pH 8.2 with contact time of 7 min (Jiang and Lloyd, 2002). A 10 mg Fe (VI)/l of dose achieved significant antimicrobials removal during water treatment (Sharma et al., 2008). Fe (VI) effectively removed chlorine resistant bacteria (Gombos et al., 2012). Sharma (2010) comprehensively reviewed the application of Fe (VI) as an oxidant for the removal of nitrogen containing organic and inorganic compounds. Ferrate 
(VI) effectively oxidized phenolic endocrine disrupting chemicals (EDCs) and phenols, and second order kinetics was reported (Lee et al., 2005). N-nitrosodimethylamine (NDMA) was completely oxidized by $1.1 \mathrm{mg} / \mathrm{l}$ of Fe (VI) dose (Lee et al., 2008). Lee et al., (2009) attained $80 \%$ phosphate and 97\% micropollutants (sulfamethoxable, diclofenac and carbamazepine) removal by $7.5 \mathrm{mg} F(\mathrm{VI}) / 1$ and $5 \mathrm{mg} \mathrm{Fe}(\mathrm{VI}) / \mathrm{l}$, from secondary wastewater effluent. At $\mathrm{pH} 8$, ferrate (VI) oxidized benzene, allylbenzene and phenol in the range of $18-47 \%, 85-100 \%$ and $32-55 \%$ respectively and maximum oxidation was observed at 3:1 molar ratio of ferrate (VI) to organics (Jiang et al., 2005). The removal efficiency of ciprofloxacin (CIP) was reported to be $80 \%$ by mere $1 \mathrm{mg} / \mathrm{l}$ of Fe (VI) dose (Jiang et al., 2012b). Lee et al., (2004) reported that ferrate can reduce COD and $\mathrm{BOD}_{5}$ of secondary wastewater effluent significantly. The ferrate (VI) dose of 15 $\mathrm{mg} / \mathrm{l}$ attained almost $83 \%$ COD removal (COD was reduced from $40 \mathrm{mg} / \mathrm{l}$ to $7 \mathrm{mg} / \mathrm{l}$ ) when applied to secondary wastewater treatment (Jiang et al., 2005). The ferrate (VI) dose of less than $10 \mathrm{mg} / \mathrm{l}$ achieved $93 \%$ Biochemical oxygen demand $\left(\mathrm{BOD}_{5}\right)$ removal from domestic secondary effluent (Jiang and Lloyd, 2002). The full scale trials of online ferrate generation and application of ferrate (VI) were carried out at Halisham North Wastewater Treatment Plant of Southern Water Ltd., UK by Jiang et al., (2012a). The average removals of $\mathrm{SS}$, phosphate, $\mathrm{COD}$ and $\mathrm{BOD}_{5}$ reported were $64 \%, 44 \%, 46 \%$ and $40 \%$ respectively by $0.16 \mathrm{mg} / \mathrm{l}$ of $\mathrm{Fe}(\mathrm{VI})$ dose at $\mathrm{pH}$ above 9 . The soluble organics removal was not investigated.

The applicability of Fe (VI) treatment as a tertiary treatment for removal of various EDCs, pharmaceutical products from secondary wastewater effluent was effectively demonstrated (Yang et al., 2012). Ferrate (VI) successfully oxidized alcohol (Norcross et 
al., 1997), chlorinated phenols (Graham et al., 2004), arsenic (Lee et al., 2003), humic substances (Graham et al., 2010; Jiang and Wang, 2003; Lim and Kim, 2010), cyanides (Flip et al., 2011), glucose, fructose, maltose, sucralose (Sharma et al., 2012), steroidal estrogens from dairy waste lagoon effluent (Remsberg et al., 2008), Bisphenol A (Zhang et al., 2012), Benzotriazoles (Yang et al., 2011) and ibuprofen (Sharma and Mishra, 2006). The effective removal of heavy metals ( $\mathrm{Cu}, \mathrm{Mn}, \mathrm{Zn})$ (Lim and Kim, 2010), algae (Ma and Liu, 2002) and color (White and Franklin, 1998) using ferrate (VI) has been reported.

\subsubsection{Synthesis of ferrate (VI)}

Stahl in 1702 , was the first to observe red purple color solution when he dissolved the molten residue, formed by heating of saltpaper and iron filings, into water (Jiang and Lloyd, 2002). The heating of iron ore and potash yielded a same color to Eckenberg and Becquerel in early $19^{\text {th }}$ century (Jiang and Lloyd, 2002). The colored solution was later identified as potassium ferrate (Jiang and Lloyd, 2002; Macova et al., 2009). Fe (VI) was very rarely studied in $19^{\text {th }}$ and early $20^{\text {th }}$ century because of its highly unstable nature, difficult synthesis method and low yield (Tiwari et al., 2005). The enhanced oxidation properties and unique performance ability brought ferrate (VI) back into attention in late $20^{\text {th }}$ century. There are three methods for synthesis of ferrate (VI) (Jiang Lloyd, 2002; Tiwari et al., 2005; Sharma et al., 2005; Yu and Licht, 2008):

\subsubsection{Electrochemical synthesis method}

In this method, the ferrate is produced by oxidizing an anode made up of iron or iron salts in a strong alkaline solution at a desired anode potential (Denvir and Pletcher, 1996; 
Sharma et al., 2005). Following equations represents the preparation of Fe (VI) using electrochemical method (Jiang and Lloyd, 2002).

At anode:

$\mathrm{Fe}+8 \mathrm{OH}^{-} \rightarrow \mathrm{FeO}_{4}{ }^{2-}+4 \mathrm{H}_{2} \mathrm{O}+6 \mathrm{e}^{-}$

At cathode:

$2 \mathrm{H}_{2} \mathrm{O} \rightarrow \mathrm{H}_{2}+2 \mathrm{OH}^{-}-2 \mathrm{e}^{-}$

Overall Reactions:

$\mathrm{Fe}+2 \mathrm{OH}^{-}+2 \mathrm{H}_{2} \mathrm{O} \rightarrow \mathrm{FeO}_{4}{ }^{2-}+3 \mathrm{H}_{2}$

$\mathrm{FeO}_{4}{ }^{2-}+2 \mathrm{~K}^{+} \rightarrow \mathrm{K}_{2} \mathrm{FeO}_{4}$

The efficiency of the ferrate produced depends on the current density, composition of anodes and also on the concentration of electrolytes (Jiang and Lloyd, 2002). More the carbon content, higher is the efficiency (Tiwari et al., 2005). A current efficiency of 35\% was achieved at the optimum current density of $36 \mathrm{~A} / \mathrm{m}^{2}, 16 \mathrm{M} \mathrm{NaOH}$ solution and $0.11 \%$ carbon content of steel (Alsheyab et al., 2010). The current yield achieved by raw iron, steel and cast iron were $15 \%, 27 \%$ and $50 \%$ respectively, at $10 \mathrm{~A} / \mathrm{m}^{2}$ current density and 16.5 M NaOH (Tiwari et al., 2005). This method of preparation has been used widely for online generation of $\mathrm{Fe}(\mathrm{VI})$ since it uses nontoxic raw materials and produces pure dissolved Fe (VI) product (Jiang et al., 2009; Sharma et al., 2005). The yield obtained by this synthesis method is low and further preparation of solid Fe (VI) is difficult (Sharma et al., 2005; Lescuras -Darrou et al., 2002). 


\subsubsection{Dry synthesis method}

This method is also called thermal oxidation, since the iron oxide is fused with oxidants at high temperature and pressure (Sharma et al., 2005; Tiwari et al., 2005). This method is the oldest method used for the preparation of ferrate (VI) (Jiang and Lloyd, 2002). The ferric oxide was fused with sodium peroxide in the presence of oxygen and in a desired molar ratio at an elevated temperature $\left(370{ }^{\circ} \mathrm{C}\right)$ produced sodium ferrate (VI) (Kopelev et al., 1992). The galvanizing wastes were fused with ferric oxide at $800{ }^{\circ} \mathrm{C}$. The mixture was then reacted with sodium peroxide at high temperature to produce sodium ferrate (Jiang and Lloyd, 2002). The dry oxidation method comes with a safety concern due to high temperature and pressure conditions and also the yield of produced ferrate is low (Tiwari et al., 2005).

\subsubsection{Wet synthesis method}

In this method, the ferric salts are made to oxidize using strong oxidants in presence of concentrated alkaline medium to produce ferrate (VI). Thompson et al., (1951) reacted ferric chloride with sodium hypochlorite in presence of sodium hydroxide to produce sodium ferrate. In order to prepare stable ferrate derivative, sodium ferrate was further reacted with potassium hydroxide (White and Franklin, 1998). Following are the reactions that generally occur in wet synthesis method:

$$
\begin{aligned}
& 2 \mathrm{FeCl}_{3}+3 \mathrm{NaOCl}+10 \mathrm{NaOH} \rightarrow 2 \mathrm{Na}_{2} \mathrm{FeO}_{4}+9 \mathrm{NaCl}+5 \mathrm{H}_{2} \mathrm{O} \\
& \mathrm{Na}_{2} \mathrm{FeO}_{4}+2 \mathrm{KOH} \rightarrow \mathrm{K}_{2} \mathrm{FeO}_{4}+2 \mathrm{NaOH}
\end{aligned}
$$


An on-site ferrate reactor was developed by Ferrate Treatment Technologies (FTT) based on the concept of wet synthesis and was named as Ferrator (Crampi and Daly, 2009). The raw materials used are ferric chloride, sodium hypochlorite, sodium hydroxide and potassium hydroxide. Ferrator is used for disinfection, destruction of emerging contaminants and odor control (Alig et al., 2011). The major drawback of this synthesis method is its low yield (10-15\%) and numerous separation steps are required to obtain solid potassium ferrate making it an expensive procedure (Sharma et al., 2005, Tiwari et al., 2005).

\subsubsection{Ferrate Analysis (Luo et al., 2011)}

\subsubsection{Volumetric titration method}

In this method, the samples containing Fe (VI) oxidizes the chromite salt.

$$
\mathrm{Cr}(\mathrm{OH})_{4}{ }^{-}+\mathrm{FeO}_{4}{ }^{2-}+3 \mathrm{H}_{2} \mathrm{O} \rightarrow \mathrm{Fe}(\mathrm{OH})_{3}\left(\mathrm{H}_{2} \mathrm{O}\right)_{3}+\mathrm{CrO}_{4}{ }^{2-}+\mathrm{OH}^{-}
$$

The oxidized chromate is then titrated with standard ferrous salt solution in acidic medium. The sodium diphenylamine sulfonate is used as an indicator. The quantitative determination of Fe (VI) from submolar to molar level is possible with this method. The biggest disadvantage of this method is that the waste needs to be stored and treated before disposal as it produces chromium residual.

\subsubsection{UV-Visible spectroscopy}

The characteristic reddish purple color of Fe (VI) corresponds to the visible and infrared spectrum at about 500 and $800 \mathrm{~nm}$. Denvir and Pletcher (1996) reported the absorption 
spectrum of $\mathrm{Fe}(\mathrm{VI})$ at $505 \mathrm{~nm}$ while some researchers quoted it to be $510 \mathrm{~nm}$ (Sharma et al., 1998). The molar absorptivity of Fe (VI) was confirmed to be $1150 \mathrm{M}^{-1} \mathrm{~cm}^{-1}$.

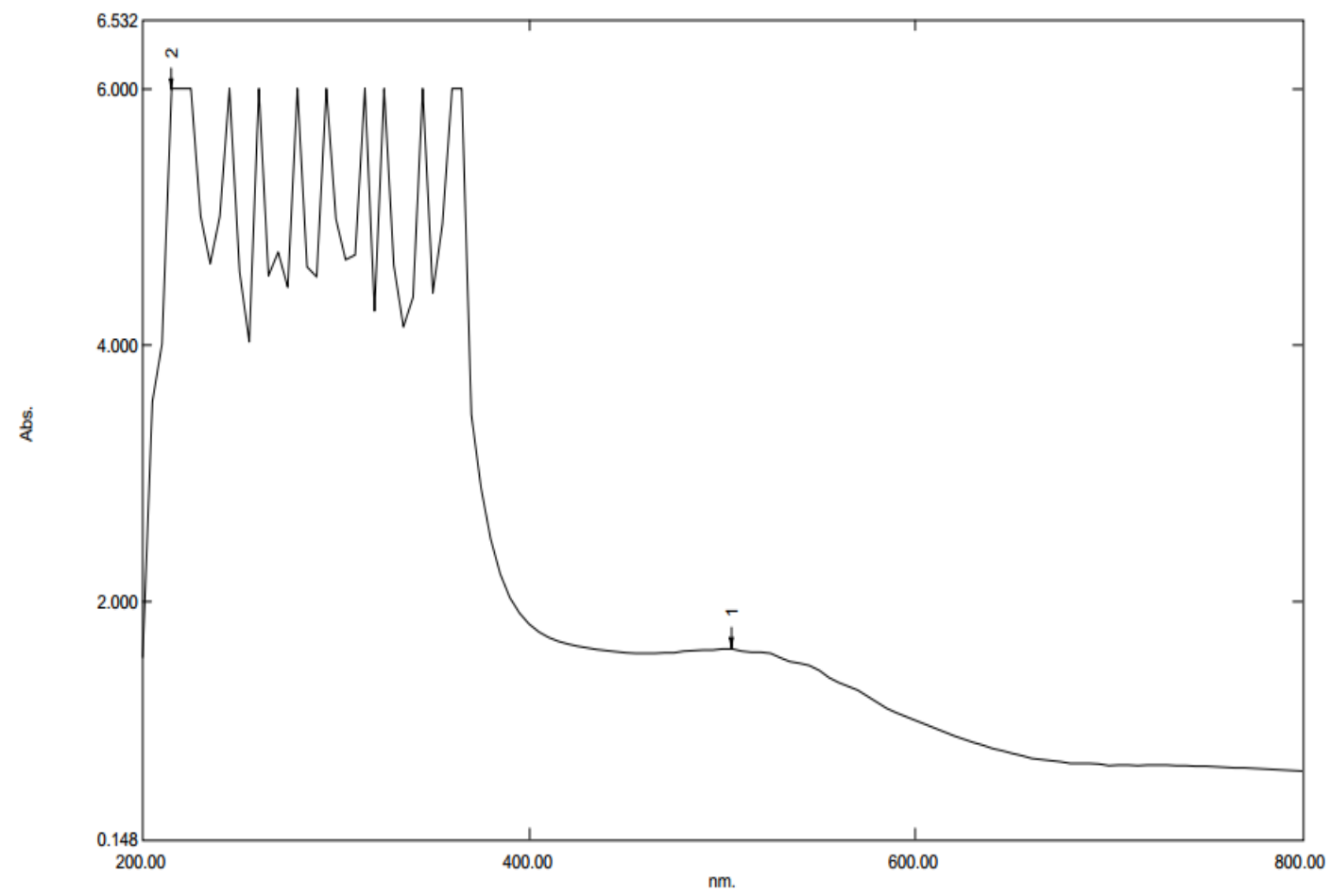

Figure 2.7: UV-Vis spectrum of Fe (VI) (Jiang and Lloyd, 2002)

\subsection{Objectives of present research}

Based on literature review, it was found that the commercial physical-chemical treatment techniques (Actiflo, DensaDeg and CoMag) used for the treatment of CSOs do not remove soluble organics. Apart from this, they use large quantities of coagulants and flocculants, and also the startup time required is high. Ferrate (VI) appeared to be a potential chemical that can treat CSOs in short contact time with a very low dose. From the literature it was noted that, only ferric salts have been used as an iron source for the synthesis of Fe (VI) using wet oxidation method, leaving the scope for evaluating 
different iron sources for Fe (VI) synthesis. Moreover it was also noted that the Fe (VI) using wet oxidation method produces low yield aqueous Fe (VI) and the preparation of solid ferrate (VI) is very expensive as it requires many separation steps. The preparation of ferrate (VI) in-situ can help to solve the above mentioned issue. Iron is present in wastewater biosolids (Patterson and Kodukula, 1984), which are abundantly available at the WWTP.

Following are the questions which were attempted in this study

Can Fe (VI) be an effective chemical for treatment of CSO especially for the removal of soluble organics and nitrogen?

Can Fe (VI) be synthesized from different iron source other than ferric compounds especially wastewater biosolids (PS and TWAS) to evaluate the feasibility of in-situ generation?

\subsection{References}

Alig, C.; Daly, L.; Huban, C.; Casson, L. (2011) Ferrate Versus Chlorine Disinfection: Disinfection By-Product Reduction and Other Benefits. Proceedings of the Water Environment Federation, Cincinnati, Ohio, April 10-12, pp. 350-355.

Alsheyab, M.; Jiang, J. Q.; Stanford, C. (2010) Electrochemical Generation of Ferrate (VI): Determination of Optimum Conditions. Desalination, 254, 175-178.

Atlantic Agriculture (2005) Constructed Wetlands for the Treatment of Agricultural Wastewater in Atlantic Canada; Atlantic Committee on Land and Engineering. 
Backman, R.C.; and Irwin, J. (2012) Advanced Nutrient Removal and Capacity Expansion Using BioMag and CoMag Ballasted Solids Wastewater Technologies. Siemens water technologies.

Blumenschein, C. D.; Latker, E.; Banerjee, K. (2006) Sand Ballasted High Rate Clarification Process for Treatment of Process Water. IWC, 6, 20.

Brombach, H.; Weiss, G.; Pisano, W. C. (2008) Clarifier-type CSO Tanks: Hydraulic Design for Optimum Sedimentation Efficiency. 11th International Conference on Urban Drainage; Edinburgh, Scotland, UK.

Bourke Jr., M. R. (2000) Full Scale Study of Chemically Enhanced Primary Treatment in Riviera de Sao Lourenco, Brazil (Doctoral dissertation, Massachusetts Institute of Technology).

Chagnon, F.; Harleman, D. R. (2004) An Introduction to Chemically Enhanced Primary Treatment.

Ciampi, L. E.; Daly, L. J. (2009) U.S. Patent No. 7,476,324. Washington, DC: U.S. Patent and Trademark Office.

Denvir, A.; Pletcher, D. (1996) Electrochemical Generation of Ferrate Part I: Dissolution of an Iron Wool Bed Anode. Journal of Applied Electrochemistry, 26, 815-822.

Dittami, J. (2008) Phosphorous Reduction in the Assabet River. Doctoral dissertation; Worcester Polytechnic Institute. 
Field, R., Sullivan, D., \& Tafuri, A. N. (2003) Management of combined sewer overflows. CRC Press.

Frank, D. A.; Smith III, T. F. (2006) Side By Side By Side The Evaluation of Three High Rate Process Technologies for Wet Weather Treatment.

Filip, J.; Yngard, R. A.,; Siskova, K.; Marusak, Z.; Ettler, V.; Sajdl, P.; Sharma, V.K.; Zboril, R. (2011) Mechanisms and Efficiency of the Simultaneous Removal of Metals and Cyanides by Using Ferrate (VI): Crucial Roles of Nanocrystalline Iron(III) Oxyhydroxides and Metal Carbonates. Chemistry-a European Journal, 17, 10097-10105.

Graham, N.; Jiang, C. C.; Li, X. Z.; Jiang, J. Q.; Ma, J. (2004) The Influence of pH on the Degradation of Phenol and Chlorophenols by Potassium Ferrate. Chemosphere, 56, 949956.

Graham, N.J.D.; Khoi, T.T.; Jiang, J.Q. (2010) Oxidation and Coagulation of Humic Substances by Potassium Ferrate. Water Science and Technology, 62, 929-936.

Gombos, E.; Felfoldi, T.; Barkacs, K.; Vertes, C.; Vajna, B.; Zaray, G. (2012) Ferrate Treatment for Inactivation of Bacterial Community in Municipal Secondary Effluent. Bioresource Technology, 107, 116-121.

Harleman, D. R. F.; Murcott, S. E. (1992) Upgrading and Multi-Stage Development of Municipal Wastewater Treatment Plants: Applicability of Chemically Enhanced Primary Treatment. Technical Report.

Hardy, C. (2008) Assabet River and Phosphorous Removal Options. 
Haydar, S.; Aziz, J. A. (2009) Characterization and Treatability Studies of Tannery Wastewater using Chemically Enhanced Primary Treatment (CEPT)—A Case Study of Saddiq Leather Works. Journal of hazardous materials, 163, 1076-1083.

Jiang, J. Q.; Lloyd, B. (2002) Progress in the Development and Use of Ferrate (VI) Salt as an Oxidant and Coagulant for Water and Wastewater Treatment. Water Research, 36, 1397-1408.

Jiang, J.Q.; Wang, S. (2003) Enhanced Coagulation with Potassium Ferrate (VI) for Removing Humic Substances. Environmental Engineering Science, 20, 627-633.

Jolis, D.; Ahmad, M. L. (2004) Evaluation of High-Rate Clarification for Wet-WeatherOnly Treatment Facilities. Water Environment Research, 474-480.

Jiang, J. Q.; Wang, S.; Panagoulopolous, A. (2005) Comparative Performance of Potassium Ferrate (VI) in Drinking Water and Sewage Treatment. In Proceedings of the 9th International Conference on Environmental Science and Technology; Rhodes Island, Greece pp. 1-3.

Jiang, J. Q.; Wang, S.; Panagoulopoulos, A. (2006) The Exploration of Potassium Ferrate (VI) as a Disinfectant/Coagulant in Water and Wastewater Treatment. Chemosphere, 63, 212-219.

Jiang, J. Q.; Stanford, C.; Alsheyab, M. (2009) The Online Generation and Application of Ferrate (VI) for Sewage Treatment-A Pilot Scale Trial. Separation and Purification Technology, 68, 227-231. 
Jiang, J. Q.; Stanford, C.; Mollazeinal, A. (2012a) The Application of Ferrate for Sewage Treatment: Pilot-to Full-Scale Trials. Global NEST Journal, 14, 93-99.

Jiang, J. Q.; Zhou, Z.; Pahl, O. (2012b) Preliminary Study of Ciprofloxacin (CIP) Removal by Potassium Ferrate (VI). Separation and Purification Technology, 88, 95-98.

Kopelev, N. S.; Perfiliev, Y. D.; Kiselev, Y. M. (1992) Mössbauer Study of Sodium Ferrates (IV) and (VI). Journal of Radioanalytical and Nuclear chemistry, 162, 239-251.

Kadlec, R. H.; Knight, R. L. (1996) Treatment Wetlands, $1^{\text {st }}$ ed.; Lewis Publishers, CRC Press: Boca Raton, FL.

Krebs, P.; Holzer, P.; Huisman, J. L.; Rauch, W. (1999) First Flush of dissolved Compounds. Water Science and Technology, 39, 55-62.

Leng, J.; Strehler, A.; Bucher, B.; Gellner, J.; Kennedy, K.; Neethling, J. B. (2002) High Rate Primary Treatment Emerging Technologies. Proceedings of the Water Environment Federation, pp. 483-503.

Lescuras-Darrou, V. M. W. Y.; Lapicque, F.; Valentin, G. (2002) Electrochemical Ferrate Generation for Wastewater Treatment Using Cast Irons with High Silicon Contents. Journal of Applied Electrochemistry, 32, 57-63.

Lee, Y.; Um, I.H.; Yoon, J. (2003) Arsenic(III) Oxidation by Iron(VI) (Ferrate) and Subsequent Removal of Arsenic(V) by Iron(III) Coagulation. Environmental Science \& Technology, 37, 5750-5756. 
Lee, Y.; Cho, M.; Kim, Y.J.; Yoon, J. (2004) Chemistry of ferrate (Fe (VI)) in Aqueous Solution and its Applications as a Green Chemical. Inustrial and Enineering Chemistry, $10,161-171$.

Lee, Y.; Yoon, J.; Von Gunten, U. (2005) Kinetics of the Oxidation of Phenols and Phenolic Endocrine Disruptors during Water Treatment with Ferrate (Fe (VI)). Environmental Science \& Technology, 39, 8978-8984.

Landon, S.; Donahue, C.; Jeyanayagam, S.; Cruden, D. (2006) Rain check. Water Environment \& Technology, 18, 30-35.

Lien, C. A.; Kruzic, A. P. (2006) The Role of Activated Sludge Solids in an Actiflo System. Proceedings of the Water Environment Federation, pp. 6748-6759.

Lee, C.; Lee, Y.; Schmidt, C.; Yoon, J.; Von Gunten, U. (2008) Oxidation of Suspected N-Nitrosodimethylamine (NDMA) Precursors by Ferrate (VI): Kinetics and Effect on the NDMA Formation Potential of Natural Waters. Water Research, 42, 433-441.

Lee, Y.; Zimmermann, S. G.; Kieu, A. T.; Von Gunten, U. (2009) Ferrate (Fe (VI)) Application for Municipal Wastewater Treatment: A Novel Process for Simultaneous Micropollutant Oxidation and Phosphate Removal. Environmental Science \& Technology, 43, 3831-3838.

Lee, Y.; Von Gunten, U. (2010) Oxidative Transformation of Micropollutants during Municipal Wastewater Treatment: Comparison of Kinetic Aspects of Selective (Chlorine, Chlorine dioxide, Ferrate (VI), and Ozone) and Nonselective Oxidants (Hydroxyl Radical). Water Research, 44, 555-566. 
Lim, M.; Kim, M.-J. (2010) Effectiveness of Potassium Ferrate $(\mathrm{K}(2) \mathrm{FeO}(4))$ for Simultaneous Removal of Heavy Metals and Natural Organic Matters from River Water. Water Air and Soil Pollution, 211, 313-322.

Luo, Z.; Strouse, M.; Jiang, J. Q.; Sharma, V. K. (2011) Methodologies for the Analytical Determination of Ferrate (VI): A Review. Journal of Environmental Science and Health, Part A, 46, 453-460.

Morrissey, S. P.; Harleman, D. R. (1992) Retrofitting Conventional Primary Treatment Plants for Chemically Enhanced Primary Treatment in the USA. In Chemical Water and Wastewater Treatment II; Springer Berlin-Heidelberg, pp. 401-416.

Ma, J.; Liu, W. (2002) Effectiveness and Mechanism of Potassium Ferrate (VI) Preoxidation for Algae Removal by Coagulation. Water Research, 36, 871-878.

Metcalf \& Eddy, Inc. (2003) Wastewater Engineering: Treatment and Reuse, 4th ed.; Mc Graw-Hill: New York.

Mácová, Z.; Bouzek, K.; Híveš, J.; Sharma, V. K.; Terryn, R. J.; Baum, J. C. (2009) Research Progress in the Electrochemical Synthesis of Ferrate (VI).Electrochimica Acta, 54, 2673-2683.

McLean, R. C. (2009) Honduras Wastewater Treatment: Chemically Enhanced Primary Treatment and Sustainable Secondary Treatment Technologies for use with Imhoff tanks. Doctoral dissertation; Massachusetts Institute of Technology. 
McHale, K. (2011) Phosphorous removal using ballasted flocculation. In $18^{\text {th }}$ Annual AWEA Speciality Conference, Morrilton, Arkansas, September 12-13.

Meyer, D.; Molle, P.; Esser, D.; Troesch, S.; Masi, F.; Dittmer, U. (2013) Constructed Wetlands for Combined Sewer Overflow Treatment-Comparison of German, French and Italian Approaches. Water, 5, 1-12.

Norcross, B. E.; Lewis, W. C.; Gai, H.; Noureldin, N. A.; Lee, D. G. (1997) The Oxidation of Secondary Alcohols by Potassium Tetraoxoferrate (VI). Canadian Journal of Chemistry, 75, 129-139.

Patterson, J. W.; Kodukula, P. S. (1984) Metals Distributions In Activated Sludge Systems. Journal (Water Pollution Control Federation), 432-441.

Plum, V.; Dahl, C. P.; Bentsen, L.; Petersen, C. R.; Napstjert, L.; Thomsen, N. B. (1998) The Actiflo Method. Water Science and Technology, 37, 269-275.

Ponist, J. B.; Scheiter, D. (2006) Ballasted High Rate Clarification Process Removes City of Greenfield, Indiana as a CSO Community. Proceedings of the Water Environment Federation, pp. 278-290.

Pratt, C.; Parece, T.; King, K.; Jenkins, T.; Amirhor, P.; Hart, C. (2008) Phosphorous Removal Technologies in Tertiary Treatment. NEWEA Annual Conference; Boston, Massachusetts. 
Remsberg, J. R.; Rice, C. P.; Kim, H.; Arikan, O.; Moon, C. (2008) Removal of Estrogenic Compounds in Dairy Waste Lagoons by Ferrate (VI). In ACS symposium series; Oxford University Press. pp. 420-433.

Sawey, R. W.; Gerrity, D.; West, R. (1999) Implementing Alternative Wet Weather Treatment Technology; Camp Dresser \& McKee; Fort Worth, Texas.

Sharma, V. K.; Rivera, W.; Smith, J. O.; O'Brien, B. (1998) Ferrate (VI) oxidation of aqueous cyanide. Environmental science \& technology, 32, 2608-2613.

Sharma, V. K. (2002) Potassium ferrate (VI): An Environmentally Friendly Oxidant. Advances in Environmental Research, 6, 143-156.

Sharma, V.; Kazama, F.; Jiangyong, H.; Ray, A. (2005) Ferrates (Iron (VI) and Iron (V)): Environmentally Friendly Oxidants and Disinfectants. Journal of Water Health, 3, 45-58.

Sharma, V. K.; Mishra, S. K. (2006) Ferrate (VI) Oxidation of Ibuprofen: A Kinetic Study. Environmental Chemistry Letters, 3, 182-185.

Sierra Legal (2006) The Great Lakes Sewage Report Card; A Sierra Legal Report.

Sharma, V. (2007) Disinfection Performance of Fe (VI) in Water and Wastewater: A Review. Water Science \& Technology, 55, 225-232.

Sharma, V. K. (2008) Oxidative Transformations of Environmental Pharmaceuticals by $\mathrm{Cl}_{2}, \mathrm{ClO}_{2}, \mathrm{O}_{3}$, and $\mathrm{Fe}(\mathrm{VI})$ : Kinetics assessment. Chemosphere, 73, 1379-1386. 
Sharma, V. K.; Li, X. Z.; Graham, N.; Doong, R. A. (2008) Ferrate (VI) Oxidation of Endocrine Disruptors and Antimicrobials in Water. Journal of Water Supply: Research and Technology-AQUA, 57, 419-426.

Sharma, V.K. (2010) Oxidation of Nitrogen-Containing Pollutants by Novel Ferrate (VI) Technology: A Review. Journal of Environmental Science and Health Part aToxic/Hazardous Substances \& Environmental Engineering, 45, 645-667.

Sharma, V. K.; Sohn, M.; Anquandah, G. A.; Nesnas, N. (2012) Kinetics of the Oxidation of Sucralose and Related Carbohydrates by Ferrate (VI). Chemosphere, 87, 644-648.

Thompson, G. W.; Ockerman, L. T.; Schreyer, J. M. (1951) Preparation and Purification of Potassium Ferrate (VI). Journal of the American Chemical Society, 73, 1379-1381.

Tiwari, D.; Yang, J.; Lee, S. (2005) Applications of Ferrate (VI) in the Treatment of Wastewaters. Environmental Engineering Research, 10, 269-282.

US Environmental Protection Agency (1988) Constructed Wetlands and Aquatic Plant Systems for Municipal Wastewater Treatment; EPA/625/1-88/022; Cincinnati, Ohio.

US Environmental Protection Agency (1994) Combined-sewer Overflow (CSO) Control Policy; Federal Register, 59 (75) 18688.

US Environmental Protection Agency (1999a) Combined Sewer Overflow Management Fact Sheet: Sewer Separation; EPA 832-F-99-041; Washington, D.C.

US Environmental Protection Agency (1999b) Combined Sewer Overflow Technology Fact Sheet: Retention Basins; EPA 832-F-99-042; Washington, D.C. 
US Environmental Protection Agency (2001) Report to Congress: Implementation and Enforcement of the CSO Control Policy; EPA 833-R-01-003; Washington, DC.

US Environmental Protection Agency (2003) Wastewater Technology Fact Sheet: Ballasted Flocculation; EPA 832-F-03-010; Washington, D.C.

US Environmental Protection Agency (2004) Report to Congress: Impacts and Control of CSOs and SSOs; EPA 833-R-04-001; Washington, DC.

Uhl, M.; Dittmer, U. (2005) Constructed Wetlands for CSO Treatment: An Overview of Practice and Research in Germany. Water Science and Technology, 51, 23-30.

US Environmental Protection Agency (2008a) Guidance: A Screening Assessment of the Potential Impacts of Climate Change on Combined Sewer Overflow (CSO) Mitigation in the Great Lakes and New England Regions; EPA/600/R-07/033F; Washington, D.C.

US Environmental Protection Agency (2008b) Emerging Technologies for Wastewater Treatment and In Plant Wet Weather Management; EPA 832-R-06-006; Fairfax, Virginia.

US Environmental Protection Agency (2013) Emerging Technologies for Wastewater Treatment and In Plant Wet Weather Management; EPA 832-R-12-011; Fairfax, Virginia.

White, D. A.; Franklin, G. S. (1998) A Preliminary Investigation into the Use of Sodium Ferrate in Water Treatment. Environmental Technology, 19, 1157-1161. 
Yu, X.; Licht, S. (2008) Advances in Electrochemical Fe(VI) Synthesis and Analysis. Journal of Applied Electrochemistry, 38, 731-742.

Yang, B.; Ying, G. G.; Zhang, L. J.; Zhou, L. J.; Liu, S.; Fang, Y. X. (2011) Kinetics Modeling and Reaction Mechanism of Ferrate (VI) Oxidation of Benzotriazoles. Water Research, 45, 2261-2269.

Yang, B.; Ying, G.G.; Zhao, J.L.; Liu, S.; Zhou, L.J; Chen, F. (2012) Removal of Selected Endocrine Disrupting Chemicals (EDCs) and Pharmaceuticals and Personal care Products (PPCPs) during Ferrate (VI) Treatment of Secondary Wastewater Effluents. Water Research, 46, 2194-2204.

Zukovs, G., and Marsalek, J. (2004) Planning and Design of Combined Sewer Overflow Treatment. Water Quality Research Journal of Canada, 39, 439-448.

Zhu, W.; Seth, R.; Lalman, J. (2007) Evaluation of a Microcarrier Weighted Coagulation Flocculation Process for the Treatment of Combined Sewer Overflow. Environmental Technology, 28, 761-770.

Zhang, P.Y.; Zhang, G.M.; Dong, J.H.; Fan, M.H.; Zeng, G.M. (2012) Bisphenol A Oxidative Removal by Ferrate (Fe (VI)) under a Weak Acidic Condition. Separation and Purification Technology, 84, 46-51. 


\section{Chapter 3}

\section{Treatment of Combined Sewer Overflows using Ferrate (VI)}

\subsection{Introduction}

Combined Sewer Overflows (CSOs) treatment has become an immediate and urgent requirement due to the environmental threat it possess. Various physical-chemical treatment techniques like Actiflo, DensaDeg, CoMag and CEPT are available to treat CSOs. Actiflo (USFilter, Kruger Products, Cary, North Carolina) is a ballasted high rate clarification process, combining coagulation, flocculation and sedimentation process (Plum et al., 1998). A coagulant is added for destabilizing colloidal particles, followed by the addition of microsand which provides large surface area to prepare floc and then a polymer which aids flocculation and subsequent sedimentation is added (Landon et al., 2006). The Actiflo plant set up for the treatment of $100 \mathrm{~m}^{3} / \mathrm{h}$ CSOs at the intercepting sewer in Lyngby-Taarbaek municipality in the Capital Region of Denmark, achieved SS, COD and TP removal of $80 \%, 85 \%$ and $55 \%$ respectively (Plum et al., 1998). The typical hydraulic retention time (HRT) is 4-7 min (EPA, 2003). DensaDeg 4D (ONDEO Degremont, Inc., Richmond, Virginia) is a high rate ballasted clarification process that uses thickened recirculated sludge as ballast (Landon et al., 2006). Jolis and Ahmad in 2004 reported that the DensaDeg 4D pilot plant set up at Southeast Water Pollution Control Plant (SEWPCP) in San Francisco, California, achieved removal of $90 \%$ of SS and $60 \%$ of COD at an HRT of $20 \mathrm{~min}$, and $80 \mathrm{mg} / \mathrm{l}$ and $1 \mathrm{mg} / \mathrm{l}$ ferric chloride and polymer dose, respectively. CoMag (Siemens, inc., Alpharetta, Georgia) uses magnetite as a ballasting agent along with regular coagulation and flocculation process (EPA, 
2013). The CoMag treatment process (Screening, Grit Removal, CoMag, UV Disinfection) usually achieves $\mathrm{BOD}_{5}, \mathrm{COD}$ and $\mathrm{TP}$ removal efficiencies of $60 \%, 50 \%$ and $99 \%$ respectively, at an HRT of 5-15 min depending on plant capacity (Backman and Irwin, 2012). In chemically enhanced primary treatment (CEPT) chemicals are added to enhance coagulation and flocculation in order to effectively remove pollutants from wastewater (Haydar and Aziz, 2009). Jin et al., (2013) reported that the pilot plant set at an urban catchment in Tianjin, China attained $63 \%, 82 \%$ and $81 \%$ of COD, TP and SS removal at 70mg/l dose of poly aluminium chloride (PAC).

The above mentioned physical-chemical treatment methods do not remove soluble organics and nitrogen from wastewater (Plum et al., 1998; EPA, 2013). Apart from this, many chemicals are required to be dosed in the system which can pose a threat to the environment and necessitates more maintenance (EPA, 2003). The typical startup time required by Actiflo, DensaDeg and CoMag is 15-30 minutes. The soluble organics present in CSO are a potential threat to aquatic environment and should be reduced. Development of a low cost oxidation and coagulation treatment process with no start up time and short contact time for the treatment of CSO can significantly mitigate adverse environmental impacts. Ferrate (VI) is the potential chemical that can meet these criteria.

Ferrate (VI) $\left(\mathrm{FeO}_{4}{ }^{2-}\right)$ is a strong oxidizing agent (Sharma, 2002; Jiang et al., 2006; Tiwari et al., 2005). Ferrate(VI) is quickly reduced to ferric or ferrous compound which acts as a coagulant thus providing double benefit with a single chemical (Sharma et al., 2005). There are numerous findings reported by researchers on the Fe (VI) treatment of water. The use of ferrate (VI) as a disinfectant in water and wastewater has been well reviewed by Sharma in 2007. Ferrate (VI) was used to oxidize endocrine disrupting compounds, 
phenols (Lee et al., 2005), antimicrobials (Sharma et al. 2008), N- nitrosodimethylamine (NDMA) (Lee, 2008), alcohol (Norcross et al., 1997), ciprofloxacin (Jiang et al., 2012), glucose, fructose, maltose, sucralose (Sharma et al., 2012), benzotriazoles (Yang et al., 2011), recalcitrant compounds (EDTA and sulfamethaoxazole) (Sharma et al., 2008) and ibuprofen (Sharma and Mishra, 2006). The use of ferrate (VI) for removal of toxic metals and non-metals (Bartzatt et al., 1992), coagulation of colloidal particles (Jiang et al., 2001) and removal of color (Jiang and Wang, 2003) from water has been addressed. The use of ferrate (VI) for the treatment of wastewater has been limited and can be attributed to the fact that $\mathrm{Fe}(\mathrm{VI})$ is very unstable and the cost required for the production of solid and stable ferrate (VI) is high. Alig et al., (2011) reported that the Ferrator, an on-site ferrate synthesis reactor, is used for disinfection, color removal, destruction of emerging contaminants and odor control. Stanford et al., (2010) reported the removal of $80 \%$ of TSS, $70 \%$ of TCOD and $90 \%$ TP from wastewater at a dose of around $2 \mathrm{mg} / \mathrm{l}$ of Fe (VI) generated electrochemically. The removal of soluble organics was not investigated.

Ferrate (VI) can be synthesized by three methods, (1) dry synthesis, (2) wet synthesis and (3) electrochemical synthesis (Jiang and Lloyd, 2002; Sharma et al., 2005). Dry synthesis is a high temperature oxidation process. Ferric salt and an oxidant are heated at high temperature to produce Fe (VI). The ferric oxide when reacted with sodium peroxide in the presence of oxygen and in a desired reagent molar ratio at $370^{\circ} \mathrm{C}$ produces sodium ferrate (Kopelev et al., 1992). The dry oxidation method for synthesis of ferrate comes with a safety concern due to high temperature. In the wet synthesis method, ferrous and ferric salts are oxidized in strong alkaline medium to produce ferrate (VI). Ferric chloride is made to react with sodium hypochlorite in the presence of sodium hydroxide to 
produce sodium ferrate (Thompson et al., 1951). White and Franklin in 1998 reported that Ferrate (VI) can be produced by reacting ferric hydroxide with potassium hydroxide with addition of chlorine. The major drawback of using the wet synthesis method is that the yield achieved is very low and the ferrate (VI) produced requires further purification (Sharma et al., 2005). The general principle of electrochemical synthesis of ferrate is to oxidize an anode, made of iron or iron salt, in a strong electrolyte using a desired anode potential to produce sodium or potassium ferrate (Jiang and Lloyd, 2002; LescurasDarrou et al., 2002). The electrochemical synthesis method has few limitations including low yield (Denvir and Pletcher, 1996).

Iron is present in wastewater sludges (Patterson and Kodukula, 1984; Jenkins et al., 1981). Iron (II) and Iron (III) salts are coagulants, precipitants and are also for odor removal in many water resources recovery facilities (Jiang and Graham, 1998; Perkowski and Kos, 2002). Iron occurs generally in two states, especially soluble ferrous iron and insoluble ferric iron (Vance, 1994). In sludge, iron is mostly present in amorphous form (Georgaki et al., 2004). The inavailability of exact speciation of iron in municipal sludges and variability of sludge composition have refrained researchers from using sludge as an iron source for generation of Fe (VI).

This chapter discusses the synthesis of Fe (VI) by oxidation of wastewater biosolids mainly primary sludge (PS) and thickened waste activated sludge (TWAS) using the wet synthesis method. It is important to note that PS and TWAS have never been reported as sources for $\mathrm{Fe}(\mathrm{VI})$ generation in the open literature. 
The objectives of the present study were twofold: (1) to assess the treatment efficiency of Fe (VI) for soluble organics, nitrogen, and phosphorous found in CSOs; and (2) to synthesize ferrate (VI) using PS and TWAS to evaluate the feasibility of in-situ generation.

\subsection{Materials and Methods}

Iron (II) sulfate heptahydrate, sodium hypochlorite solution $(\mathrm{NaOCl})$ and potassium hydroxide pellets $(\mathrm{KOH})$ were obtained from Sigma Aldrich (Oakville, ON, Canada). The $1 \mathrm{M}$ hydrochloric acid solution, $1 \mathrm{M}$ sodium hydroxide $(\mathrm{NaOH})$ solution, $0.45 \mu \mathrm{m}$ polypropylene filters, $1.2 \mu \mathrm{m}$ syringe filters and whatman glass microfiber filters were obtained from VWR International (Mississauga, ON, Canada). The source of commercial grade ferrate (VI) was the potassium ferrate sample obtained from Regional Centre of Advanced Technologies and Materials (Olomouc, Czech Republic). The composition of $1 \mathrm{~g}$ of sample was as follows: $21.3 \% \mathrm{~K}_{2} \mathrm{FeO}_{4}, 59.4 \% \mathrm{KFeO}_{2}, 19.3 \% \mathrm{KOH}$ or $\mathrm{K}_{2} \mathrm{O}$. Thus 1 $\mathrm{g}$ of sample contained $0.06 \mathrm{~g}$ of $\mathrm{Fe}(\mathrm{VI})$. The raw waste water (RWW), primary sludge (PS) and waste activated sludge (WAS) were collected from the Adelaide Pollution Control plant located in London (ON, Canada). The combined sewer overflow (CSO) water was prepared in lab by diluting RWW with distilled water in the ratio of 1:2. The waste activated sludge was settled and the supernatant was removed in order to thicken WAS. Total iron in PS and TWAS was determined after, PS and TWAS samples were digested. The $\mathrm{pH}$ of PS and TWAS samples were adjusted to 3 using $\mathrm{HCl}$ solution. The samples were then kept in a preheated oven at $105^{\circ} \mathrm{C}$ for $30 \mathrm{~min}$. The samples were then filtered using $0.45 \mu \mathrm{m}$ polypropylene filters. The iron content in the samples was determined by inductively coupled plasma- optical emission spectrometer (ICP-OES, 
Varian Vista Pro; CCD Simultaneous, Australia). In order to determine the soluble iron using ICP-OES, the PS and TWAS samples were filtered using $0.45 \mu \mathrm{m}$ polypropylene filters without digestion.

\section{Water Quality Analysis}

Total suspended solids (TSS), volatile suspended solids (VSS), total biochemical oxygen demand $\left(\mathrm{TBOD}_{5}\right)$, and soluble biochemical oxygen demand $\left(\mathrm{SBOD}_{5}\right)$ were analyzed according to the Standard Methods (APHA, 1998). HACH methods and testing kits (HACH Odyssey DR/2500) were used to measure total chemical oxygen demand (COD), soluble chemical oxygen demand (SCOD), total phosphorus (TP), total nitrogen (TN), soluble nitrogen $(\mathrm{SN}), \mathrm{NH}_{4}$ and $\mathrm{PO}_{4}{ }^{3-}$. Samples were filtered using $0.45 \mu \mathrm{m}$ polypropylene filters in order to determine soluble parameters. Oakton $\mathrm{pH}$ meter was used to measure the $\mathrm{pH}$ of samples. The residual chlorine analysis was performed using the Thermo Scientific Orion AQUAfast II colorimeter. Table 3.1 represents the water quality parameters for the RWW. 
Table 3.1: Raw waste water (RWW) characteristics

\begin{tabular}{|c|c|}
\hline Characteristics & RWW \\
\hline TSS (mg/l) & $250 \pm 80$ \\
\hline VSS (mg/l) & $200 \pm 60$ \\
\hline$\overline{\text { TCOD }(\mathrm{mg} / \mathrm{l})}$ & $314 \pm 36$ \\
\hline$\overline{\mathrm{SCOD}(\mathrm{mg} / \mathrm{l})}$ & $124 \pm 44$ \\
\hline TBOD $_{5}(\mathrm{mg} / \mathrm{l})$ & $180 \pm 26$ \\
\hline SBOD $_{5}(\mathrm{mg} / \mathrm{l})$ & $75 \pm 25$ \\
\hline TN (mg/l) & $28 \pm 4$ \\
\hline$\overline{\text { STN (mg/l) }}$ & $19.2 \pm 3$ \\
\hline $\mathrm{NH}_{4}(\mathrm{mg} / \mathrm{l})$ & $14.7 \pm 1.5$ \\
\hline TP (mg/l) & $6.9 \pm 1.1$ \\
\hline $\mathrm{PO}_{4}{ }^{3-}(\mathrm{mg} / \mathrm{l})$ & $3.4 \pm 1$ \\
\hline
\end{tabular}

Experimental procedures

In order to determine the applicability of ferrate (VI) for the treatment of CSO, standard jar tests were performed. All the six beakers with 1-L capacity each were filled with laboratory prepared combined sewer overflow. The $\mathrm{pH}$ was adjusted to 7 using $\mathrm{HCl}$ or $\mathrm{NaOH}$. The Fe (VI) was added as dry powder instead of stock solution, since Fe (VI) is very unstable and reacts with water quickly to form Fe (III) compound. One beaker was considered as blank while the other five beakers were dosed with $0.3 \mathrm{mg} \mathrm{Fe}$ (VI), $0.6 \mathrm{mg}$ Fe (VI), $1.5 \mathrm{mg} \mathrm{Fe}(\mathrm{VI}), 15 \mathrm{mg} \mathrm{Fe}(\mathrm{VI})$ and $30 \mathrm{mg} \mathrm{Fe}(\mathrm{VI})$. The mixture was then stirred at the speed of $100 \mathrm{rpm}$ for 30 seconds, after which the mixing speed was reduced to 30 rpm for the next $30 \mathrm{~min}$, in order to promote flocculation. Stirring was stopped and mixture was made to settle for $30 \mathrm{~min}$ before the collection of sample. Water quality analysis was carried out on the samples to determine the effectiveness of Fe (VI) for 
treatment of CSOs. In order to check the consistency of the results, experiments were carried out three times.

\section{Dose Optimization}

The results obtained from the aforementioned experiments defined the effective range of Fe (VI). To determine the optimum dose of ferrate (VI), the jar test apparatus and procedure was kept the same as mentioned earlier. One beaker was considered blank and the other five beakers were spiked with $0.12 \mathrm{mg} \mathrm{Fe}(\mathrm{VI}), 0.24 \mathrm{mg} \mathrm{Fe}(\mathrm{VI}), 0.36 \mathrm{mg} \mathrm{Fe}$ (VI), $0.48 \mathrm{mg} \mathrm{Fe}(\mathrm{VI})$ and $0.6 \mathrm{mg} \mathrm{Fe}(\mathrm{VI})$. In order to determine the effect of $\mathrm{pH}$ on the treatment performance of $\mathrm{Fe}(\mathrm{VI})$ doses, tests were carried out at $\mathrm{pH} 6,7,8$ and 9 maintaining the same aforementioned doses. The $\mathrm{pH}$ was adjusted by using $\mathrm{HCl}$ or $\mathrm{NaOH}$ solution. The final samples collected were analyzed for the aforementioned water quality parameters. The experiments were carried out multiple times to check the accuracy of the findings.

\section{Jar Test Kinetics}

Kinetic batch studies at neutral $\mathrm{pH}$ and the optimum dose of ferrate obtained from the aforementioned jar testing were conducted in a $4 \mathrm{~L}$ completely mixed batch reactor. The mixture of ferrate (VI) and CSO was subjected to the initial stirring at $100 \mathrm{rpm}$ for 1 minute. The stirring speed was reduced to $30 \mathrm{rpm}$ for the next $4 \mathrm{~min}$, after which stirring was stopped to settle the mixture. Mixed samples were collected every minute for first five minutes and then supernatant samples were collected every five minutes for the next 15 minutes. The final supernatant sample was collected 40 minutes after the initial start time. 
Synthesis of Ferrate (VI)

Ferrate (VI) was synthesized by the wet oxidation method. Ferrous sulfate heptahydrate was oxidized using sodium hypochlorite solution under strong alkaline conditions in order to produce potassium ferrate $\left(\mathrm{K}_{2} \mathrm{FeO}_{4}\right)$. Ferrate (VI) was measured spectrophotometrically at a wavelength of $505 \mathrm{~nm}$ (Denvir and Pletcher, 1996) using a UV-VIS spectrophotometer (UV-3600, Shimadzu).

Ferrate (VI) production from biosolids

The PS and TWAS were used as an iron source to synthesize ferrate using the wet oxidation method. Table 3.2 shows the characteristics of PS and TWAS.

Table 3.2: Characteristics of PS and TWAS

\begin{tabular}{|c||c|c|c|c|c|c|}
\hline & TSS (g/l) & VSS (g/l) & TCOD (g/l) & SCOD (g/l) & $\begin{array}{c}\text { Total Fe } \\
(\mathrm{mg} / \mathbf{l})\end{array}$ & $\begin{array}{c}\text { Soluble Fe } \\
(\mathrm{mg} / \mathbf{l})\end{array}$ \\
\hline Primary Sludge & $28.1 \pm 1$ & $22.4 \pm 0.9$ & $38 \pm 0.9$ & $9.4 \pm 0.7$ & $388 \pm 24$ & $38 \pm 6$ \\
\hline TWAS & $14.7 \pm 0.7$ & $9.8 \pm 0.6$ & $13.5 \pm 0.4$ & $2.05 \pm 0.15$ & $192 \pm 10$ & $27 \pm 4$ \\
\hline
\end{tabular}

Two different procedures were performed to synthesize ferrate (VI) using sludge.

- The digested PS and TWAS were treated with sodium hypochlorite solution in the presence of potassium hydroxide. Fifteen $\mathrm{ml}$ of $50 \mathrm{~g} / \mathrm{l}$ sodium hypochlorite solution and $2 \mathrm{~g}$ of potassium hydroxide pellets were added to $5 \mathrm{ml}$ of digested PS or TWAS without filtration. Fe (VI) concentration was measured using UV-VIS spectrophotometer. 
- The digested PS and TWAS samples were filtered with $0.45 \mu \mathrm{m}$ polypropylene filters and then were subjected to the hypochlorite treatment under strong alkaline conditions. The $15 \mathrm{ml}$ of $50 \mathrm{~g} / \mathrm{l}$ sodium hypochlorite solution and $2 \mathrm{~g}$ of potassium hydroxide pellets were added to $5 \mathrm{ml}$ of digested PS or TWAS filtrate. Fe (VI) concentration was measured using UV-VIS spectrophotometer.

To check the effectiveness, $10 \mathrm{ml}$ solution of the liquid ferrate produced from different sources (ferrous sulfate heptahydrate, digested PS, digested TWAS, digested PS filtrate and digested TWAS filtrate) were dosed in the five beakers containing 1L CSO water respectively, with one beaker filled with CSO only as a blank in the above mentioned jar test. The samples were analyzed for the water quality parameters and the experiment was repeated multiple times to check the variability of the results.

\subsection{Results and Discussions}

\section{Assessment of the treatment efficiency of ferrate (VI) for soluble organics, nitrogen and phosphorous}

The applicability of ferrate (VI) for the treatment of CSOs at neutral $\mathrm{pH}$ was demonstrated using jar tests and the results obtained are presented in Figure 3.1. The removal efficiencies of TCOD, SCOD, TSS and VSS achieved by $0.3 \mathrm{mg}$ Fe (VI)/1 were $83 \%, 73 \%, 70 \%$ and $74 \%$ respectively, and those obtained by $0.6 \mathrm{mg} \mathrm{Fe}(\mathrm{VI}) / 1$ were $77 \%$, $70 \% 78 \%$ and $95 \%$ respectively. These removal efficiencies obtained by $0.3 \mathrm{mg}$ Fe (VI)/1 and $0.6 \mathrm{mg} \mathrm{Fe}(\mathrm{VI}) / 1$ were found out to be much higher than those achieved by $1.5 \mathrm{mg} \mathrm{Fe}$ (VI)/l, $15 \mathrm{mg} \mathrm{Fe}(\mathrm{VI}) / 1$ and $30 \mathrm{mg} \mathrm{Fe}(\mathrm{VI}) / 1$ dose. The $15 \mathrm{mg} \mathrm{Fe}(\mathrm{VI}) / 1$ and $30 \mathrm{mg} \mathrm{Fe}$ (VI)/l turned out to be the over dose. The dose of $0.3 \mathrm{mg}$ Fe (VI)/l showed high COD 
removal and low SS removal as compared to $0.6 \mathrm{mg} F(\mathrm{VI}) / 1$ due to more efficient reduction of SCOD.

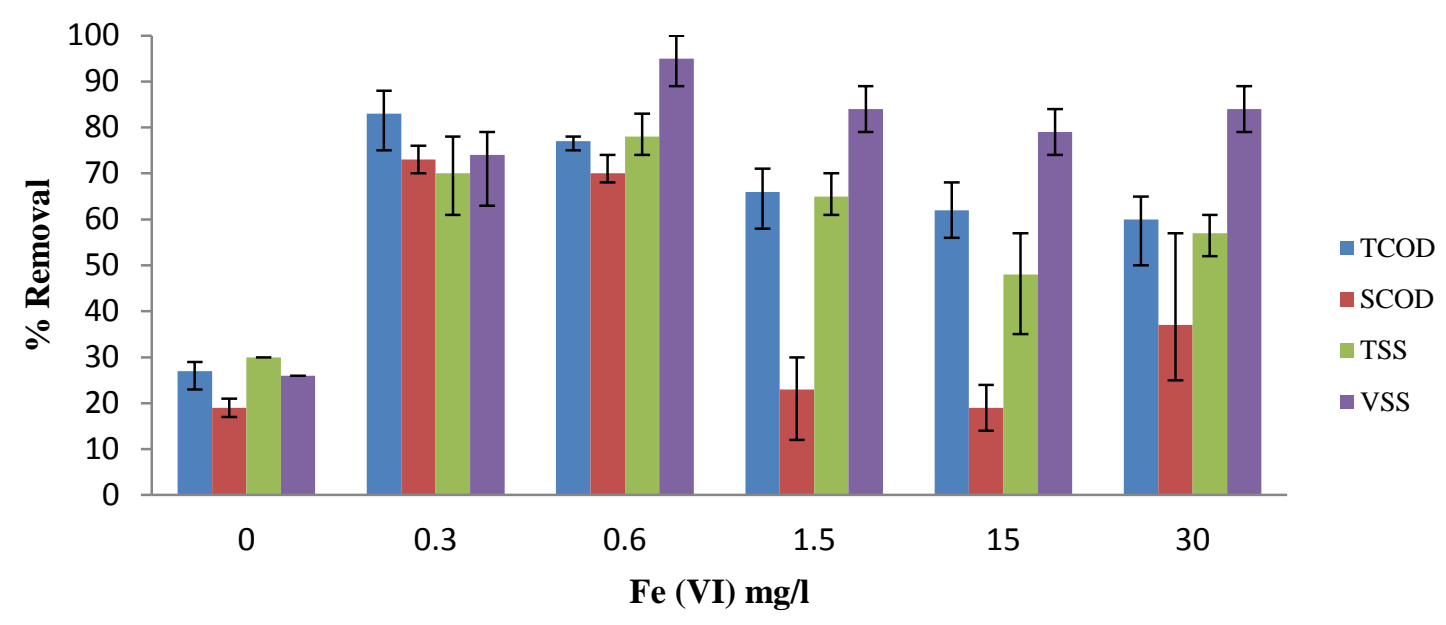

Figure 3.1: Treatment efficiency of different doses of Fe (VI) at neutral $\mathrm{pH}$

\section{Optimization}

The optimization of $\mathrm{Fe}(\mathrm{VI})$ dose required for the treatment of CSO was carried out with the range of dose figured out from the above mentioned results. The effect of $\mathrm{pH}$ on the efficiency of ferrate (VI) doses was also studied and the results are shown in Figure 3.2. The removal efficiencies of TCOD, SCOD, TSS, VSS, TP and TN obtained at pH 9 with a dose of $0.12 \mathrm{mg} / \mathrm{l} \mathrm{Fe}(\mathrm{VI})$ were $81 \%, 81 \%, 57 \%, 67 \%, 52 \%$ and $28 \%$ respectively, and found to be higher than the efficiencies obtained by the same dose at $\mathrm{pH} 6, \mathrm{pH} 7$, and $\mathrm{pH}$ 8 respectively. The main reason for the high removal efficiency at $\mathrm{pH} 9$ and at a very low dose of $\mathrm{Fe}(\mathrm{VI})$ can be attributed to the fact that Ferrate (VI) is more stable in alkaline medium. At pH 7 and a dose of $0.24 \mathrm{mg} / \mathrm{l} \mathrm{Fe}(\mathrm{VI})$, the TCOD, SCOD, TSS, VSS, TP and TN removal efficiencies of $69 \%, 69 \%, 57 \%, 75 \%, 52 \%$ and $38 \%$. The TCOD, SCOD, 
TSS, VSS, TP and TN removal efficiencies obtained from $0.12 \mathrm{mg} / \mathrm{l} \mathrm{Fe}$ (VI), $0.24 \mathrm{mg} / \mathrm{l}$ Fe (VI), $0.36 \mathrm{mg} / \mathrm{l} \mathrm{Fe}(\mathrm{VI}), 0.48 \mathrm{mg} / \mathrm{l} \mathrm{Fe}(\mathrm{VI})$ and $0.60 \mathrm{mg} / \mathrm{l} \mathrm{Fe}(\mathrm{VI})$ at $\mathrm{pH} 8$ were almost equivalent to those achieved with the same doses at $\mathrm{pH}$ 7. The optimum $\mathrm{pH}$ was decided as 7 rather than $\mathrm{pH}$ 9, considering the fact that treated CSOs will be discharged in receiving water bodies.

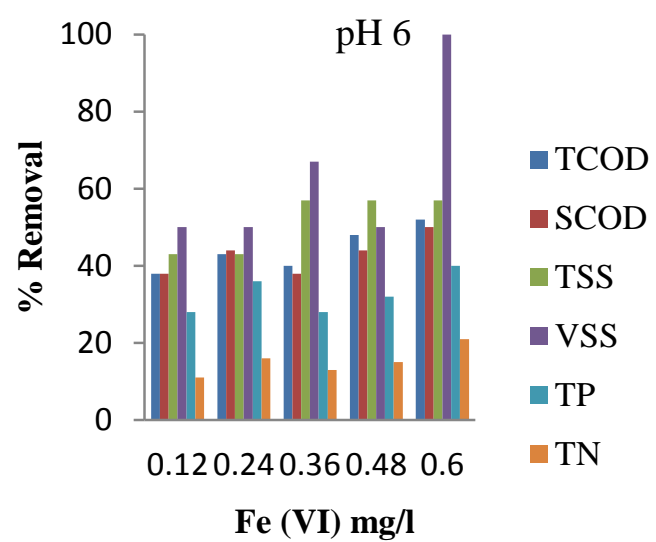

(a)

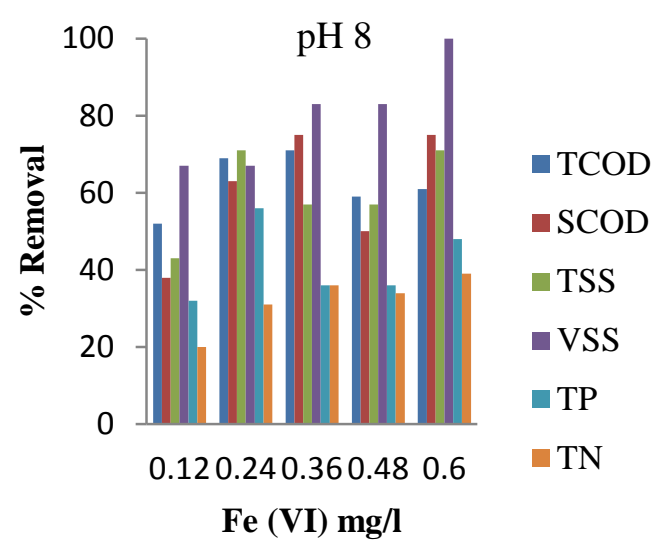

(c)

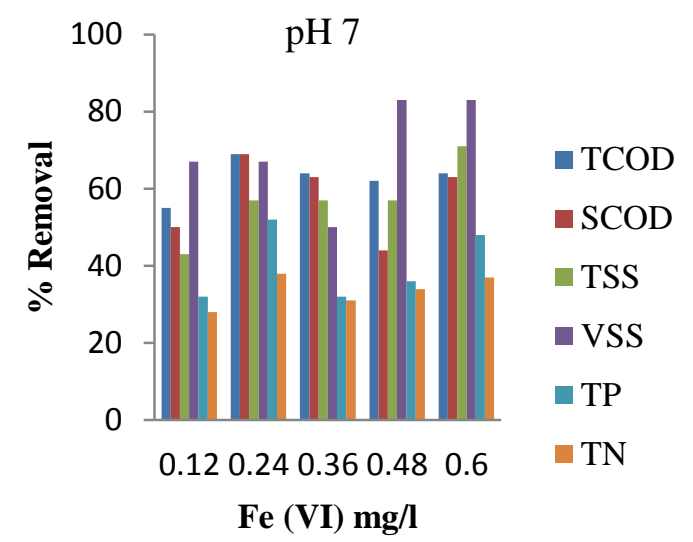

(b)

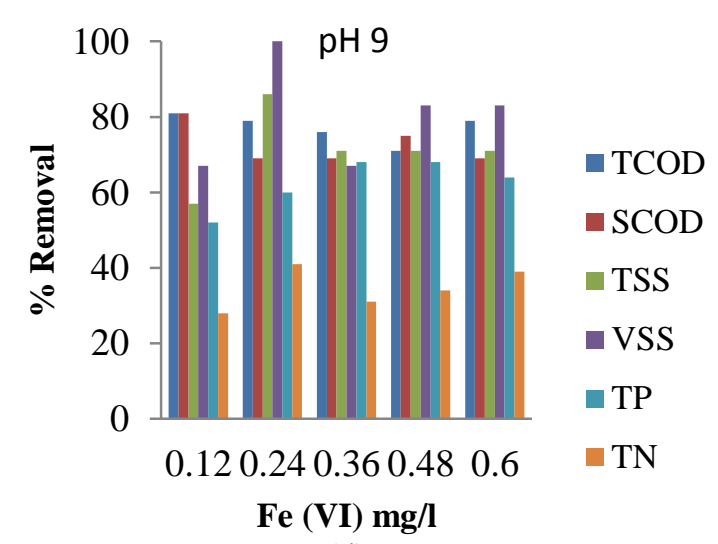

(d)

Figure 3.2: Effect of $\mathrm{pH}$ on the treatment performance of Fe (VI) doses, (a) pH 6; (b) pH 7; (c) $\mathrm{pH} 8$; (d) $\mathrm{pH} 9$ 
The removal efficiencies achieved by ferrate (VI) at $\mathrm{pH} 7$ with respect to those achieved at $\mathrm{pH} 9$ are compromised but not low. The optimum dose of $0.24 \mathrm{mg} \mathrm{Fe}(\mathrm{VI}) / 1$ at neutral $\mathrm{pH}$ was used for kinetic testing.

\section{Kinetics}

The treated CSO water characteristics and the treatment efficiency obtained by the optimum dose of $0.24 \mathrm{mg} \mathrm{Fe}(\mathrm{VI}) / 1$ are represented in Table 3.3. The very low dose of ferrate (VI) achieved treated wastewater quality comparable to secondary effluent. The soluble organics, TP, TN and STN were removed effectively by Ferrate (VI). The optimum dose of $\mathrm{Fe}(\mathrm{VI})$ removed $\mathrm{SCOD}, \mathrm{SBOD}_{5}, \mathrm{TP}, \mathrm{TN}, \mathrm{STN}$ and $\mathrm{PO}_{4}{ }^{3-}$ by $75 \%$, $68 \%, 64 \%, 38 \%, 36 \%$ and $36 \%$ respectively. It must be asserted that the removal of soluble total nitrogen without any appreciable change in ammonia indicates that soluble organic nitrogen was oxidized primarily to nitrogen gas.

Table 3.3: Treatment Efficiency of Ferrate VI ( $0.24 \mathrm{mg} / \mathrm{l}$ dose $)$

\begin{tabular}{|c|c|c|c|}
\hline & Untreated CSO (mg/l) ${ }^{*}$ & Treated CSO $(\mathrm{mg} / \mathrm{l})^{\mathrm{a}}$ & $\begin{array}{c}\text { Treatment } \\
\text { Efficiency }(\%)\end{array}$ \\
\hline TCOD & 84 & $24 \pm 3$ & $71 \pm 4$ \\
\hline SCOD & 32 & $8 \pm 1$ & $75 \pm 3$ \\
\hline TBOD $_{5}$ & 50.6 & $15.7 \pm 1.4$ & $69 \pm 3$ \\
\hline SBOD $_{5}$ & 17.9 & $5.5 \pm 0.4$ & $68 \pm 5$ \\
\hline TSS & 70 & $20 \pm 10$ & $72 \pm 15$ \\
\hline VSS & 60 & $10 \pm 10$ & $83 \pm 17$ \\
\hline TP & 2.5 & $0.9 \pm 0.2$ & $64 \pm 8$ \\
\hline TN & 9 & $5.6 \pm 0.6$ & $38 \pm 6$ \\
\hline STN & 7.4 & $4.8 \pm 0.4$ & $36 \pm 6$ \\
\hline $\mathrm{PO}_{4}{ }^{3-}$ & 1.1 & $0.7 \pm 0.1$ & $36 \pm 9$ \\
\hline $\mathrm{NH}_{4}$ & 4.8 & $4.4 \pm 0.1$ & $9 \pm 1$ \\
\hline \multicolumn{4}{|c|}{ a. Average \pm SD (Three runs) } \\
\hline *. Same CSO & was used for all the three runs & & \\
\hline
\end{tabular}


The soluble organic nitrogen $\left(\mathrm{SON}=\mathrm{STN}-\mathrm{NH}_{4}\right)$ correlated with SCOD statistically $\left(\mathrm{R}^{2}=\right.$ 0.9604) as shown in Figure 3.3 with $0.084 \mathrm{mg} \mathrm{SON} / \mathrm{mg}$ SCOD.

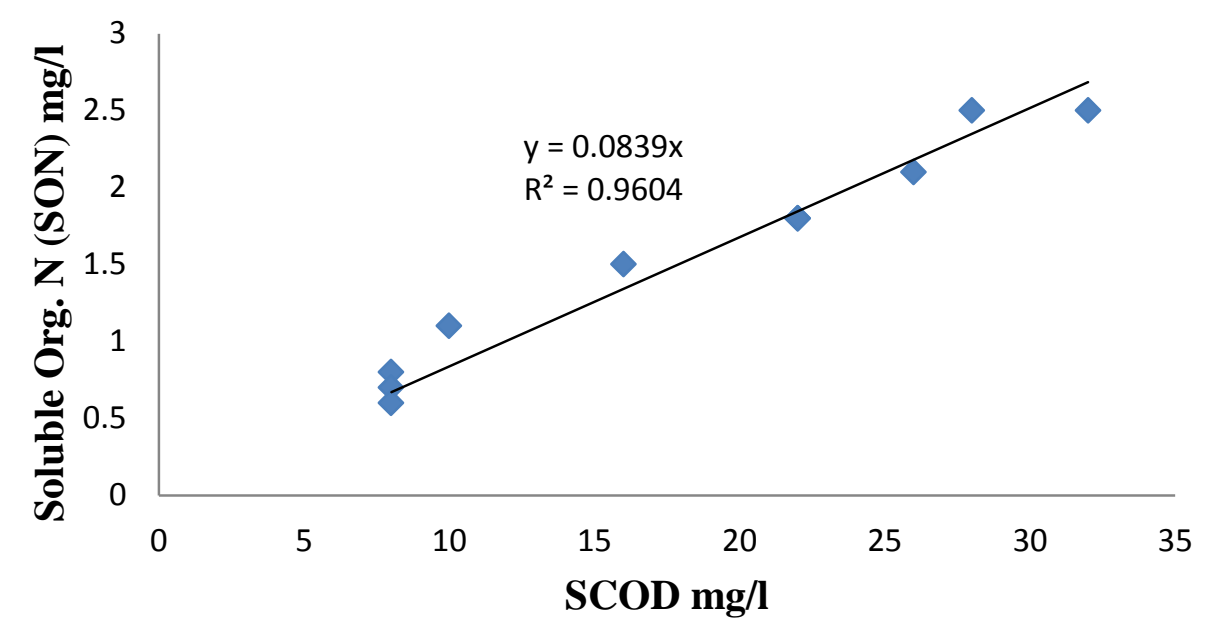

Figure 3.3: Plot of soluble organic nitrogen (SON) vs. soluble chemical oxygen demand (SCOD)

Figure $3.4 \mathrm{a}$ and $3.4 \mathrm{~b}$ respectively depict the temporal variations of organics and nutrients (i.e. $\mathrm{N}$ and P) at a dose of $0.24 \mathrm{mg} \mathrm{Fe}(\mathrm{VI}) / \mathrm{l}$. From the Figure 3.4-b, it can be noted that the $\mathrm{NH}_{4}$ was almost unaffected by $\mathrm{Fe}(\mathrm{VI})$. It is interesting to note that the required contact time of Fe (VI) for treatment is as low as $15 \mathrm{~min}$. The PCOD, SCOD, TP, TN, STN removal efficiencies of $65 \%, 75 \%, 56 \%, 34 \%, 32 \%$ respectively were attained by very low dose of ferrate $(0.24 \mathrm{mg} F(\mathrm{VI}) / \mathrm{l})$ and in very short time (15 minutes). The TSS and VSS were reduced by $71 \%$ and $66 \%$ respectively, within $15 \mathrm{~min}$ by $0.24 \mathrm{mg} \mathrm{Fe}$ (VI)/l dose (not shown). It must be asserted that the 15 minute contact time included 5 minutes of mixing and 10 minutes of settling, and as apparent from Figure 3.4, more than $46 \%, 50 \%, 32 \%, 21 \%$, and $19 \%$ of PCOD, SCOD, TP, TN, and STN removal were 
actually achieved within 5 minutes. The high SCOD removal indicates that ferrate (VI) acts as a strong oxidant and the removal of PCOD implies that Fe (VI) can be an effective coagulant.

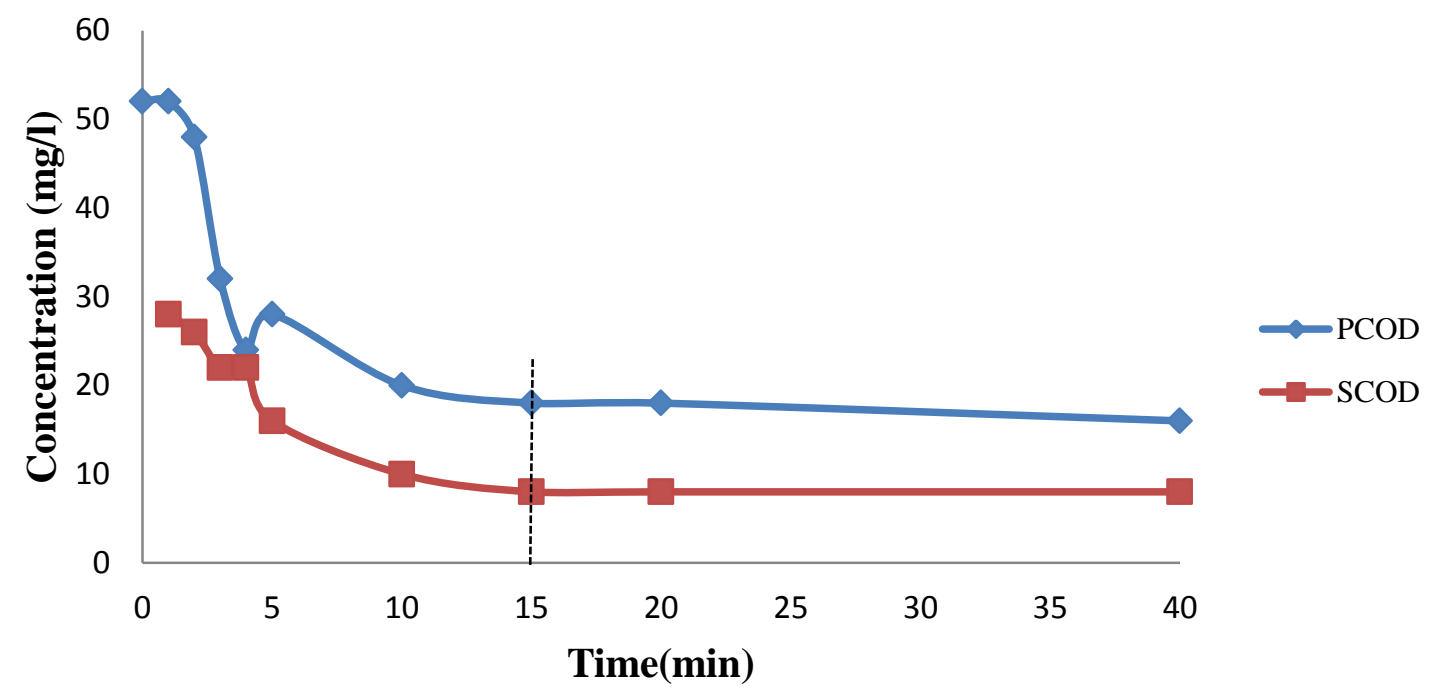

Figure 3.4-a: Effect of $0.24 \mathrm{mg} / \mathrm{l}$ ferrate (VI) dose on Concentration of PCOD and SCOD with respect to time.

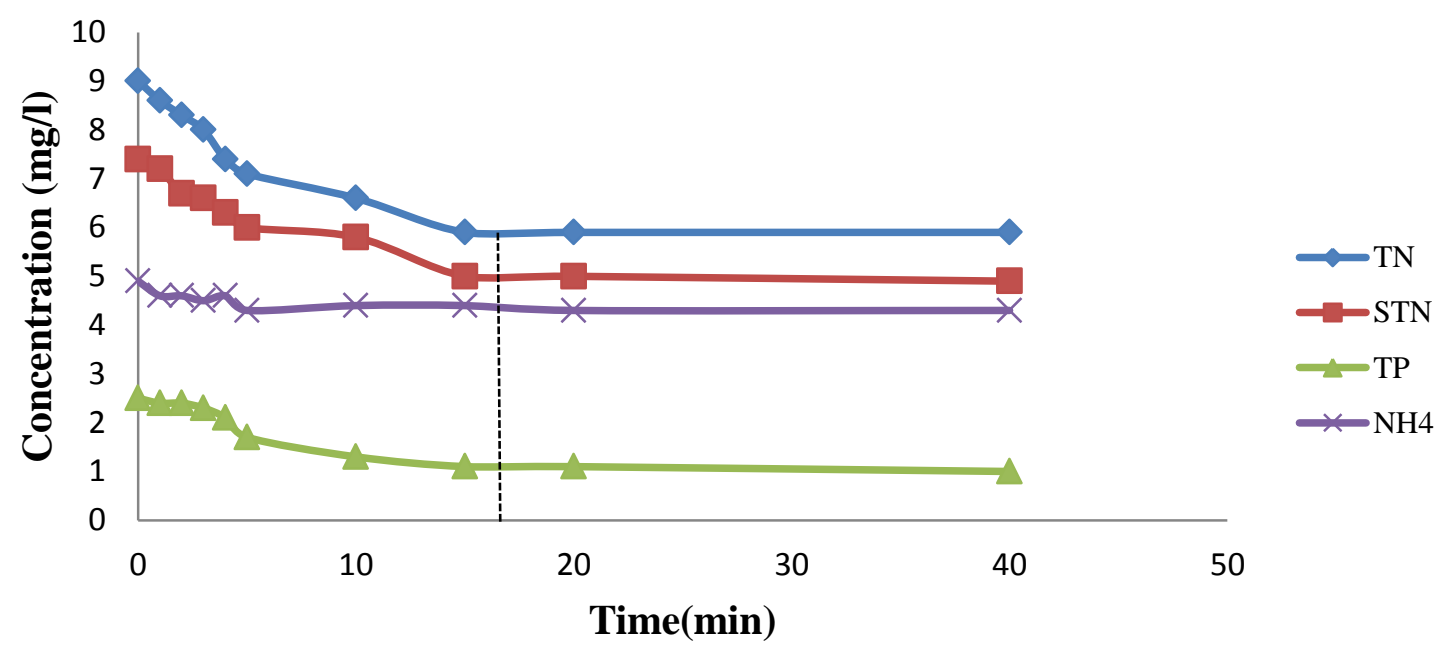

Figure 3.4-b: Effect of $0.24 \mathrm{mg} / \mathrm{l}$ ferrate (VI) dose on Concentration of TN, STN, TP and $\mathrm{NH}_{4}$ with respect to time. 
The second order model was found out to be the best fit for the reaction between water quality parameters and ferrate (VI). This can be due to reduction of ferrate into ferric ion which further acts as a coagulant. Sharma et al. (2008) reported that Fe (VI) oxidation of endocrine disruptors were modeled using second order reaction. The plot of 1/concentration of PCOD and SCOD versus time is represented in Figure 3.5. The second order rate constant $(\mathrm{k})$, of oxidation reaction at neutral $\mathrm{pH}$ was $0.0067(\mathrm{mg} / \mathrm{l})^{-1} \mathrm{~min}^{-1}$ with $\mathrm{R}^{2}$ value of 0.9734 for SCOD. The $\mathrm{k}$-value for PCOD was $0.002\left(\mathrm{mg} / \mathrm{l}^{-1} \mathrm{~min}^{-1}\right.$ signaling that removal of SCOD by ferrate is faster than PCOD removal.

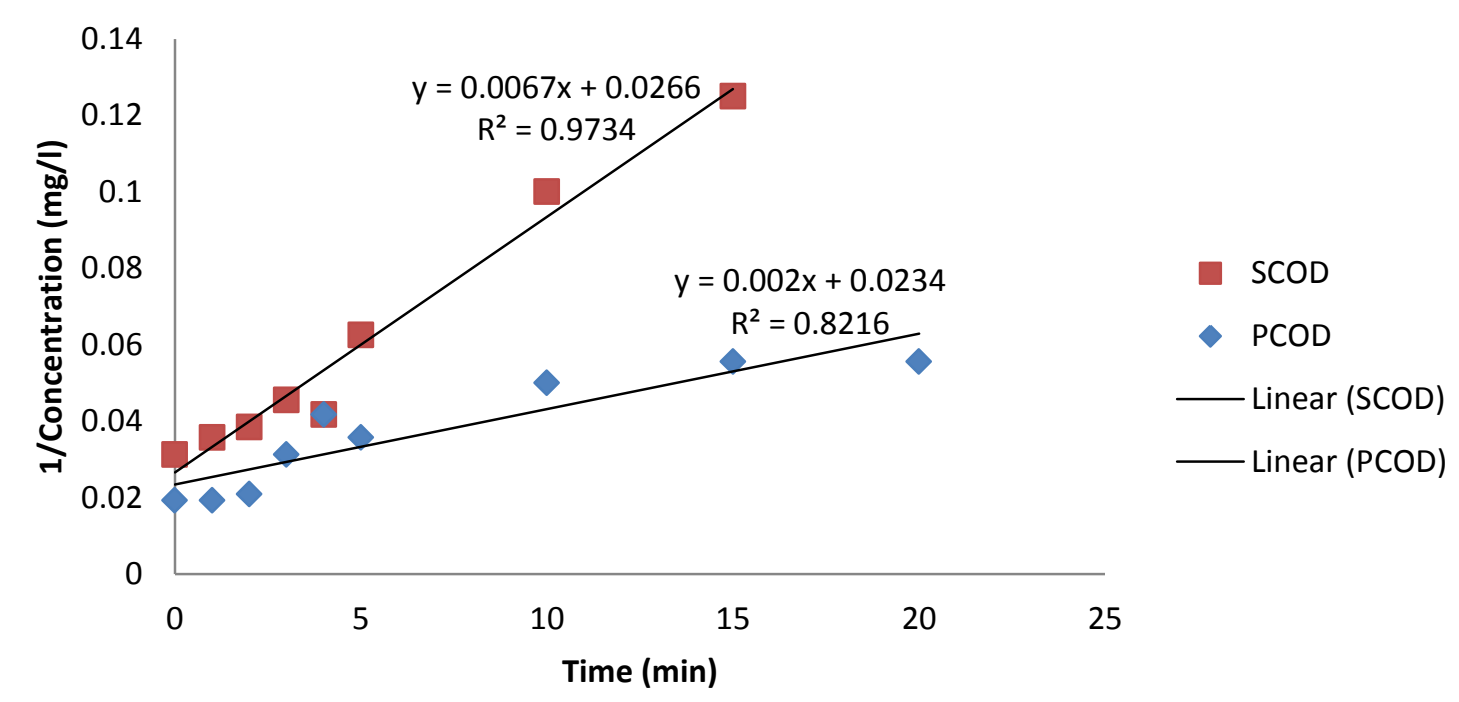

Figure 3.5: Plot of 1/Concentration of PCOD and SCOD vs. time for the ferrate dose of $0.24 \mathrm{mg} / \mathrm{l}$. (Kinetic study)

The rate constant, $\mathrm{k}$, for the reaction of $\mathrm{Fe}(\mathrm{VI})$ with $\mathrm{TCOD}$, $\mathrm{TBOD}_{5}, \mathrm{SBOD}_{5}, \mathrm{TSS}$, VSS were $0.0019(\mathrm{mg} / \mathrm{l})^{-1} \mathrm{~min}^{-1}, 0.0032\left(\mathrm{mg} / \mathrm{l}^{-1} \mathrm{~min}^{-1}, 0.0094(\mathrm{mg} / \mathrm{l})^{-1} \mathrm{~min}^{-1}, 0.0015(\mathrm{mg} / \mathrm{l})^{-}\right.$ ${ }^{1} \min ^{-1}$ and $0.0034(\mathrm{mg} / \mathrm{l})^{-1} \mathrm{~min}^{-1}$ respectively $\left(\mathrm{R}^{2}\right.$ of $0.9652,0.983,0.9771,0.8451$ and 0.9048 respectively, not shown). 


\section{Assessment of ferrate (VI) synthesis using wastewater biosolids}

The synthesis of Ferrate (VI) was carried out by wet oxidation method using ferrous sulfate heptahydrate as the iron source. Ferrous sulfate heptahydrate was added as a dry powder while sodium hypochlorite was added as $5 \%$ solution i.e. $50 \mathrm{~g} / \mathrm{l}$. The amount of ferrate (VI) produced using 2 grams of ferrous sulfate heptahydrate and 2.5 grams $/ 50 \mathrm{ml}$ of sodium hypochlorite $(50 \mathrm{~g} / \mathrm{l})$ was $0.00245 \mathrm{~g}$ corresponding to only $0.61 \%$ of the theoretical quantity i.e. the yield was a mere $0.61 \%$.

The wastewater biosolids were used as the iron source for the synthesis of ferrate (VI). Two synthesis methods as mentioned above in the materials and methods section were carried out. The amount of ferrate (VI) produced by digested PS, digested PS filtrate, digested TWAS and digested TWAS filtrate sources were measured by UV-VIS spectrophotometer and were $72 \mathrm{mg} / \mathrm{l}, 10 \mathrm{mg} / \mathrm{l}, 27 \mathrm{mg} / \mathrm{l}$ and $9 \mathrm{mg} / \mathrm{l}$ respectively. Jar tests on CSO treatment by biosolids synthesized Fe (VI) were conducted by adding $10 \mathrm{ml}$ of the ferrate (VI) solutions to $1 \mathrm{~L}$ of $\mathrm{CSO}$. The initial and the final concentrations of TCOD, SCOD, TSS and VSS for dose of $0.49 \mathrm{mg} \mathrm{Fe}$ (VI)/l, $0.72 \mathrm{mg} \mathrm{Fe} \mathrm{(VI)/l,} 0.1 \mathrm{mg} \mathrm{Fe}$ (VI)/l, $0.27 \mathrm{mg} \mathrm{Fe}(\mathrm{VI}) / \mathrm{l}$ and $0.09 \mathrm{mg} \mathrm{Fe}(\mathrm{VI}) / \mathrm{l}$ synthesized from ferrous sulfate heptahydrate, digested PS, digested PS filtrate, digested TWAS and digested TWAS filtrate respectively, are shown in Figure 3.6. The addition of Ferrate (VI) synthesized from dig PS and dig TWAS to CSO accounted for the initial rise of TCOD, SCOD, TSS and VSS while the addition of Fe (VI) produced from dig PS filtrate and dig TWAS filtrate, increased the initial concentration of TCOD and SCOD in the CSO, without any change in TSS and VSS concentrations. 


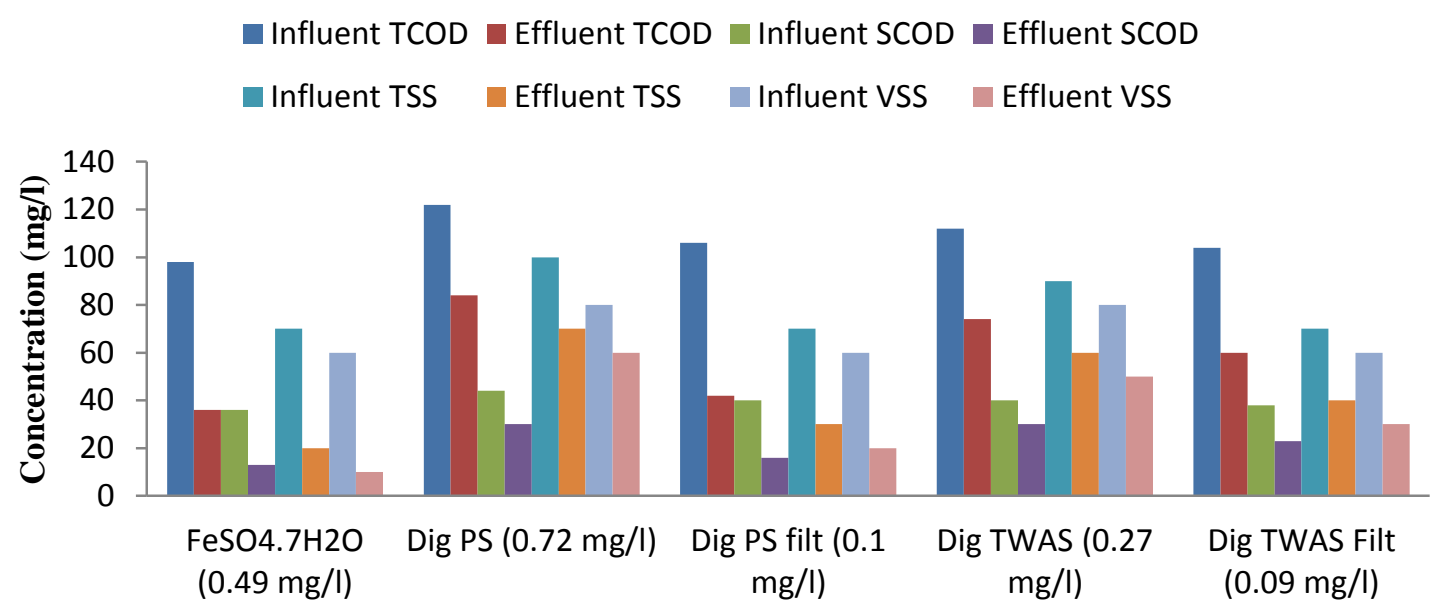

Figure 3.6: Influent and Effluent concentrations of water quality parameters obtained from ferrate doses prepared from different sources.

The concentrations of the unreacted $\mathrm{NaOCl}$ were found out to be $44 \mathrm{mg} / \mathrm{l}, 247 \mathrm{mg} / \mathrm{l}, 208$ $\mathrm{mg} / \mathrm{l}, 229 \mathrm{mg} / \mathrm{l}$ and $208 \mathrm{mg} / \mathrm{l}$ for the ferrate (VI) dose of $0.49 \mathrm{mg} / \mathrm{l}, 0.72 \mathrm{mg} / 1,0.1 \mathrm{mg} / \mathrm{l}$, $0.27 \mathrm{mg} / \mathrm{l}$ and $0.09 \mathrm{mg} / \mathrm{l}$ produced from $\mathrm{FeSO}_{4} .7 \mathrm{H}_{2} \mathrm{O}$, digested $\mathrm{PS}$, digested PS filtrate, digested TWAS, and digested TWAS filtrate respectively. The treatment efficiencies achieved by $10 \mathrm{ml}$ of each liquid ferrate solution per liter of CSO i.e. by the dose of 0.72 $\mathrm{mg} \mathrm{Fe}(\mathrm{VI}) / \mathrm{l}, 0.1 \mathrm{mg} \mathrm{Fe}(\mathrm{VI}) / \mathrm{l}, 0.27 \mathrm{mg} \mathrm{Fe}(\mathrm{VI}) / 1,0.09 \mathrm{mg} \mathrm{Fe}(\mathrm{VI}) / 1$ and $0.49 \mathrm{mg} \mathrm{Fe}$ (VI)/l synthesized from digested PS, digested PS filtrate, digested TWAS, digested TWAS filtrate and ferrous sulfate heptahydrate respectively, and their comparison with the treatment efficiency attained by the respective unreacted $\mathrm{NaOCl}$ dose of the prepared ferrate solutions are mentioned in Table 3.4. The removal efficiencies obtained by the control run without any chemical during the jar test are also listed in Table 4. The dose of $0.1 \mathrm{mg} \mathrm{Fe}(\mathrm{VI}) / 1$ synthesized by digested PS filtrate showed the higher treatment 
efficiency than the $0.72 \mathrm{mg} \mathrm{Fe}(\mathrm{VI}) / 1,0.27 \mathrm{mg} \mathrm{Fe}(\mathrm{VI}) / \mathrm{l}$ and $0.09 \mathrm{mg} \mathrm{Fe}(\mathrm{VI}) / \mathrm{l}$ doses synthesized by digested PS, digested TWAS and digested TWAS filtrate respectively.

Table 3.4: Comparative performance of ferrate (VI) produced from different source

\begin{tabular}{|c|c|c|c|c|c|c|}
\hline & \multicolumn{5}{|c|}{ Synthesized Ferrate (VI) Source } & \multirow[b]{2}{*}{$\begin{array}{c}\text { Settled } \\
\text { CSO }\end{array}$} \\
\hline & Dig. PS $\mathbf{P}^{\mathbf{a}}$ & $\begin{array}{l}\text { Dig. PS } \\
\text { Filtrate }^{b}\end{array}$ & $\begin{array}{c}\text { Dig. } \\
\text { TWAS }\end{array}$ & $\begin{array}{c}\text { Dig. } \\
\text { TWAS } \\
\text { Filtrate }^{\text {b }}\end{array}$ & $\mathrm{FeSO}_{4} \cdot 7 \mathrm{H}_{2} \mathrm{O}^{\mathrm{d}}$ & \\
\hline Dose (mg/l) & $0.72(247)$ & $0.1(208)$ & $0.27(229)$ & $0.09(208)$ & $0.49(44)$ & \\
\hline \% TCOD Removal & $31(42)$ & $60(43)$ & $34(44)$ & $42(43)$ & $63(40)$ & 29 \\
\hline \% PCOD Removal & $31(50)$ & $61(48)$ & $39(48)$ & $44(48)$ & $63(45)$ & 34 \\
\hline \% SCOD Removal & $32(28)$ & $60(33)$ & $25(36)$ & $39(33)$ & $64(31)$ & 19 \\
\hline \% TSS Removal & $30(38)$ & $57(38)$ & $33(25)$ & $43(38)$ & $71(25)$ & 25 \\
\hline$\%$ VSS Removal & $25(33)$ & $67(17)$ & $38(33)$ & $50(17)$ & $83(33)$ & 33 \\
\hline \%STN Removal & $17(14)$ & $28(10)$ & $20(14)$ & $26(10)$ & $33(7)$ & 3 \\
\hline$\% \mathrm{NH}_{4}$ Removal & $6(4)$ & $8(4)$ & $8(4)$ & $6(4)$ & $8(2)$ & \\
\hline \multicolumn{7}{|c|}{ a. Values mentioned in brackets are the removal efficiencies obtained by control run of $247 \mathrm{mg} \mathrm{NaOCl} / \mathrm{l}$ dose. } \\
\hline \multicolumn{7}{|c|}{ b. Values mentioned in brackets are the removal efficiencies obtained by control run of $208 \mathrm{mg} \mathrm{NaOCl} / \mathrm{l}$ dose. } \\
\hline \multicolumn{7}{|c|}{ c. Values mentioned in brackets are the removal efficiencies obtained by control run of $229 \mathrm{mg} \mathrm{NaOCl} / \mathrm{l}$ dose. } \\
\hline & & & & & & \\
\hline
\end{tabular}

The highest removal efficiency achieved by $0.49 \mathrm{mg}$ Fe (VI)/l dose produced by $\mathrm{FeSO}_{4} .7 \mathrm{H}_{2} \mathrm{O}$ can be justified, as the pure iron source was used for the synthesis of ferrate (VI). The dose of $0.1 \mathrm{mg}$ Fe (VI)/l synthesized from digested PS filtrate performed almost similar to the dose of $0.49 \mathrm{mg} \mathrm{Fe}(\mathrm{VI}) / \mathrm{l}$ generated from $\mathrm{FeSO}_{4} \cdot 7 \mathrm{H}_{2} \mathrm{O}$. It is hard to speculate the exact cause for this effect. One of the reasons can be the oxidation of various metals other than iron present in digested PS filtrate by sodium hypochlorite which further acted as a coagulant or oxidant in parallel with Fe (VI) thus providing better removal efficiency. The removal efficiencies achieved by the ferrate (VI) synthesized from digested sludge filtrate were better than those obtained from the ferrate (VI) synthesized from digested sludge. This indicates that the filtration of sludge caused 
the changes in binding of metal thus increasing the availability of iron for oxidation. The TCOD, PCOD, SCOD, TSS, VSS and STN removal achieved by $0.1 \mathrm{mg} \mathrm{Fe}(\mathrm{VI}) / 1$ produced from digested PS filtrate were 40\%, 27\%, 82\%, 50\%, 294\% and $180 \%$ respectively more, than the removal achieved by $208 \mathrm{mg} / \mathrm{l}$ dose of $\mathrm{NaOCl}$. The removal efficiencies of TCOD, PCOD, SCOD, TSS, VSS and STN attained just by settling (no chemical addition) were $29 \%, 34 \%, 19 \%, 25 \%, 33 \%$ and $3 \%$ respectively. Table 4 data shows that the removal efficiencies achieved by Fe (VI) generated from digested PS and digested TWAS were inferior to the efficiencies achieved by control $\mathrm{NaOCl}$ dose. This infers that, practically we cannot use digested PS and digested TWAS for generation of $\mathrm{Fe}(\mathrm{VI})$.

In order to check the coagulation and oxidation effect of Fe (VI), the treated samples obtained after jar test were filtered through $0.45 \mu \mathrm{m}$ and $1.2 \mu \mathrm{m}$ syringe filters and were tested for COD. The difference between the results obtained was considered as coagulation effect since this fraction represents the colloidal matter. Table 3.5 represents the \%COD removal attributed to coagulation achieved by ferrate (VI) synthesized from various sources. Overall coagulation contributed $42 \%, 53 \%, 39 \%, 48 \%$ and $32 \%$ of the COD removed by the $0.1 \mathrm{mg} F e(\mathrm{VI}) / 1,0.72 \mathrm{mg} \mathrm{Fe}(\mathrm{VI}) / \mathrm{l}, 0.27 \mathrm{mg} \mathrm{Fe}(\mathrm{VI}) / \mathrm{l}, 0.09 \mathrm{mg} \mathrm{Fe}$ (VI)/l and $0.49 \mathrm{mg}$ Fe (VI)/l doses synthesized by digested PS filtrate, digested PS, digested TWAS, digested TWAS filtrate and $\mathrm{FeSO}_{4} .7 \mathrm{H}_{2} \mathrm{O}$ respectively. 
Table 3.5: Contribution of the coagulation effect of Ferrate (VI) to COD removal

\begin{tabular}{|l|c|c|}
\hline Ferrate synthesis Source & $\begin{array}{c}\text { Dose (mg Fe } \\
(\mathbf{V I}) / \mathbf{l})\end{array}$ & $\begin{array}{c}\text { Coagulation } \\
(\mathbf{\%})\end{array}$ \\
\hline Digested PS Filtrate & 0.1 & 42 \\
\hline Digested PS & 0.72 & 53 \\
\hline Digested TWAS Filtrate & 0.09 & 39 \\
\hline Digested TWAS & 0.27 & 48 \\
\hline FeSO $\mathbf{4}_{\mathbf{4} .7 \mathbf{H}_{2} \mathbf{O}}$ & 0.49 & 32 \\
\hline
\end{tabular}

As treatment of CSO ferrate (VI) synthesized by digested primary filtrate source demonstrated the best results, optimization of dose experiments were performed using jar tests at neutral $\mathrm{pH}$ and $0.1 \mathrm{mg} \mathrm{Fe}(\mathrm{VI}) / 1,0.2 \mathrm{mg} \mathrm{Fe}(\mathrm{VI}) / \mathrm{l}, 0.3 \mathrm{mg} \mathrm{Fe}(\mathrm{VI}) / 1,0.4 \mathrm{mg} \mathrm{Fe}$ $(\mathrm{VI}) / \mathrm{l}$ and $0.5 \mathrm{mg} \mathrm{Fe}(\mathrm{VI}) / \mathrm{l}$ doses. The removal efficiencies of various water quality parameters for the range of $\mathrm{Fe}(\mathrm{VI})$ doses for the treatment of CSO are presented in Figure 3.7. The optimum dose was $0.1 \mathrm{mg}$ Fe (VI)/l, which removed TCOD, SCOD, TSS, VSS, TP and TN by $60 \%, 62 \%, 63 \%, 67 \%, 30 \%$ and $25 \%$ respectively. The removal efficiency of TN and TP increased with increase in Fe (VI) dose. 


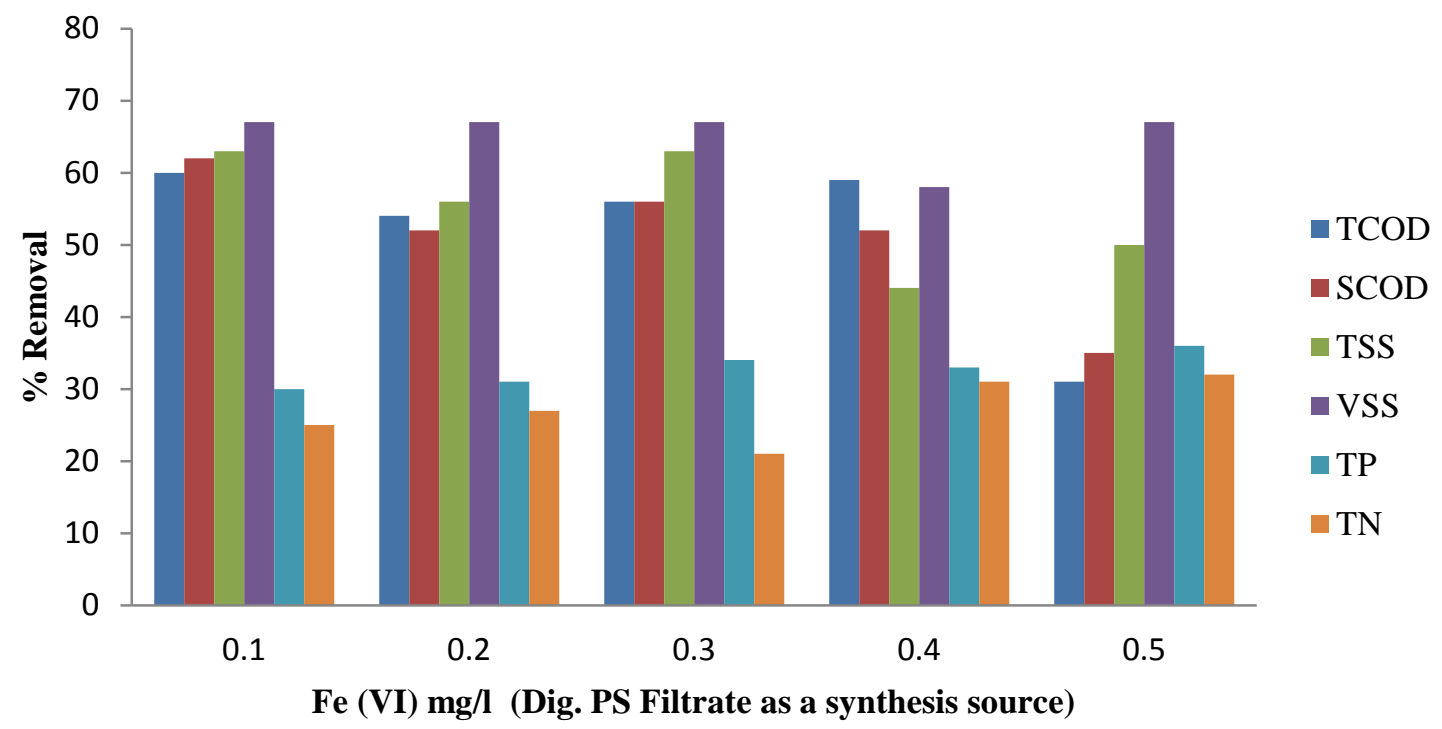

Figure 3.7: Treatment efficiency of different doses of Fe (VI) synthesized from digested PS filtrate.

\section{Effluent guidelines}

The Ontario Ministry of Environment (MOE) law sets up different standards for different sewage treatment plants. The US EPA sets bypass treatment standards on case by case. The comparison between secondary treatment effluent criteria (USEPA and Ontario $\mathrm{MOE})$ and the removal of water characteristics achieved by $0.49 \mathrm{mg} \mathrm{Fe}(\mathrm{VI}) / 1,0.1 \mathrm{mg} \mathrm{Fe}$ (VI)/l, $0.09 \mathrm{mg} \mathrm{Fe}(\mathrm{VI}) / 1$ dose synthesized from $\mathrm{FeSO}_{4} .7 \mathrm{H}_{2} \mathrm{O}$, digested PS filtrate, digested TWAS filtrate respectively, are mentioned in Table 3.6. According to Ministry of Environment (MOE) regulations for bypass treatment mentioned in procedure F-5-5, the removal efficiency of five day biochemical oxygen demand $\left(\mathrm{BOD}_{5}\right)$ and total suspended solids (TSS) should be $30 \%$ and $50 \%$ respectively. According to the US EPA, CSO related bypass flows must receive primary clarification, solids and floatables removal and disinfection. 
Table 3.6: Comparison between the Secondary Treatment Effluent Criteria and the removal of water characteristics achieved by Fe (VI) synthesized from different iron sources (Metcalf and Eddy, 2003)

\begin{tabular}{|c|c|c|c|c|c|}
\hline & \multicolumn{3}{|c|}{ Synthesized Ferrate (VI) Source } & \multirow[b]{2}{*}{$\begin{array}{c}\text { Ontario } \\
\text { (Annual } \\
\text { average } \\
\text { Effluent } \\
\text { guidelines) } \\
\end{array}$} & \multirow[b]{2}{*}{$\begin{array}{l}\text { United } \\
\text { States }\end{array}$} \\
\hline $\begin{array}{l}\text { Characteristic } \\
\text { of Discharge }\end{array}$ & $\begin{array}{c}\mathrm{FeSO}_{4.7 \mathrm{H}_{2} \mathrm{O}^{\mathrm{a}}} \\
\text { (Dose: } 0.49 \\
\mathrm{mg} / \mathrm{l})\end{array}$ & $\begin{array}{c}\text { Dig. PS } \\
\text { Filtrate }^{\mathrm{a}} \\
\text { (Dose: } 0.1^{\text {mg/l) }}\end{array}$ & $\begin{array}{l}\text { Dig. TWAS } \\
\text { Filtrate }^{\mathrm{a}} \\
\text { (Dose: } 0.09 \\
\text { mg/l) }\end{array}$ & & \\
\hline 5 day BOD $_{5}$ & $\begin{array}{c}23.9 \pm 0.1 \\
\mathrm{mg} / \mathrm{l}\end{array}$ & $\begin{array}{c}25.3 \pm 2.1 \\
\mathrm{mg} / \mathrm{l}\end{array}$ & $\begin{array}{c}36.6 \pm 3.5 \\
\mathrm{mg} / 1\end{array}$ & $25-30 \mathrm{mg} / \mathrm{l}$ & $\begin{array}{c}30 \mathrm{mg} / \mathrm{l}(30 \\
\text { day } \\
\text { average) } \\
45 \mathrm{mg} / \mathrm{l}(7 \\
\text { day } \\
\text { average) }\end{array}$ \\
\hline TSS & $\begin{array}{c}20 \pm 10 \\
\mathrm{mg} / \mathrm{l}\end{array}$ & $\begin{array}{c}30 \pm 10 \\
\mathrm{mg} / \mathrm{l}\end{array}$ & $\begin{array}{c}40 \pm 10 \\
\mathrm{mg} / 1\end{array}$ & $25-40 \mathrm{mg} / \mathrm{l}$ & $\begin{array}{c}30 \mathrm{mg} / \mathrm{l}(30 \\
\text { day } \\
\text { average) } \\
45 \mathrm{mg} / \mathrm{l}(7 \\
\text { day } \\
\text { average) }\end{array}$ \\
\hline pH & $7 \pm 0.2$ & $7.2 \pm 0.1$ & $7.2 \pm 0.2$ & ---- & $\begin{array}{l}\text { within } \\
\text { range of } 6 \\
\text { to } 9 \\
\end{array}$ \\
\hline Removal & $\begin{array}{c}61-63 \% \\
\text { BOD }_{5} \text { and } \\
57-86 \% \\
\text { TSS } \\
\end{array}$ & $\begin{array}{c}60-62 \% \\
\mathrm{BOD}_{5} \text { and } \\
43-71 \% \\
\text { TSS } \\
\end{array}$ & $\begin{array}{c}41-47 \% \\
\text { BOD }_{5} \text { and } \\
29-57 \% \\
\text { TSS } \\
\end{array}$ & ---- & $\begin{array}{c}85 \% \mathrm{BOD}_{5} \\
\text { and TSS }\end{array}$ \\
\hline erage SD & & & & & \\
\hline
\end{tabular}

The treatment of $\mathrm{CSO}$ by Ferrate (VI) synthesized using $\mathrm{FeSO}_{4} .7 \mathrm{H}_{2} \mathrm{O}$ and digested PS filtrate meets the Ontario MOE and US EPA, secondary effluent criteria and the bypass treatment removal guidelines. However CSO treatment using Fe (VI) generated from digested TWAS fails to meet these criteria. The low dose, short contact time, attainment of secondary effluent characteristics, no start up time, and the removal of soluble 
organics, nitrogen and phosphorous are the most salient advantages of ferrate (VI) treatment.

\subsection{Conclusions}

Treatment of CSOs was performed using ferrate (VI) and the following conclusions can be drawn:

- At the optimum commercial Fe (VI) dose of $0.24 \mathrm{mg} / \mathrm{l}$; TCOD, SCOD, TBOD $\mathrm{SBOD}_{5}, \mathrm{TSS}, \mathrm{VSS}, \mathrm{TP}, \mathrm{TN}$ and STN removal efficiencies of $71 \%, 75 \%, 69 \%$, $68 \%, 72 \%, 83 \%, 64 \%, 38 \%$ and $36 \%$ respectively were achieved.

- Contact time of ferrate (VI) was observed to be $15 \mathrm{~min}$; in case of continuous mixing, the contact time of Fe (VI) can be expected to be in between 5-15 min.

- Soluble organics were removed and considerable reduction in total and soluble Nitrogen was achieved.

Synthesis of ferrate (VI) from PS and TWAS, using wet oxidation synthesis technique was carried out and the ferrate (VI) produced was used for the treatment of CSO with following conclusions:

- At Fe (VI) dose of $0.1 \mathrm{mg} / \mathrm{l}$ produced using digested PS filtrate, TCOD, SCOD, TSS, VSS, TP and TN removal efficiencies of 60\%, 62\%, 63\%, 67\%, 30\% and $25 \%$ respectively. 
- Treatment efficiencies achieved by $0.1 \mathrm{mg}$ Fe (VI)/l synthesized from digested PS filtrate were comparable to those obtained from $0.49 \mathrm{mg}$ Fe (VI)/l produced from $\mathrm{FeSO}_{4} \cdot 7 \mathrm{H}_{2} \mathrm{O}$ (a pure iron source).

- Low removal efficiencies were observed for the treatment of CSO by ferrate (VI) produced from digested TWAS filtrate.

- High removal efficiency achieved by Fe (VI) prepared from filtered digested PS infers that $\mathrm{Fe}(\mathrm{VI})$ can be generated from filtered dewatering filtrate and may be more efficient and cost effective.

- Water quality characteristics of treated CSO obtained were comparable to the secondary effluent water characteristics proposed by Ontario MOE and USEPA.

\subsection{References}

Alig, C.; Daly, L.; Huban, C.; Casson, L. (2011) Ferrate versus Chlorine Disinfection: Disinfection By-Product Reduction and Other Benefits. Proceedings of the Water Environment Federation, Cincinnati, Ohio, April 10-12, pp. 350-355.

American Public Health Association; American Water Works Association; Water Environment Federation (1998) Standard Methods for the Evaluation of Water and Wastewater, $20^{\text {th }}$ ed.; Washington, D.C.

Backman, R.C.; and Irwin, J. (2012) Advanced Nutrient Removal and Capacity Expansion Using BioMag and CoMag Ballasted Solids Wastewater Technologies. Siemens water technologies. 
Bartzatt, R.; Cano, M.; Johnson, L.; Nagel, D. (1992) Removal of Toxic Metals and Nonmetals from Contaminated Water. Journal of Toxicology and Environmental Health, $35,205-210$.

Denvir, A.; Pletcher, D. (1996) Electrochemical Generation of Ferrate Part I: Dissolution of an Iron Wool Bed Anode. Journal of Applied Electrochemistry, 26, 815-822.

Georgaki, I.; Dudeney, A. W. L.; Monhemius, A. J. (2004) Characterisation of Iron-Rich Sludge: Correlations between Reactivity, Density and Structure. Minerals Engineering, 17, 305-316.

Haydar, S.; Aziz, J. A. (2009) Characterization and Treatability Studies of Tannery Wastewater using Chemically Enhanced Primary Treatment (CEPT) — A Case Study of Saddiq Leather Works. Journal of Hazardous Materials, 163, 1076-1083.

Jenkins, R. L.; Scheybeler, B. J.; Smith, M. L.; Baird, R.; Lo, M. P.; Haug, R. T. (1981) Metals Removal and Recovery from Municipal Sludge. Journal (Water Pollution Control Federation), 25-32.

Jiang, J. Q., \& Graham, N. J. (1998). Pre-Polymerized Inorganic Coagulants and Phosphorus Removal by Coagulation- A Review. Water SA, 24, 237-244.

Jiang, J. Q.; Lloyd, B.; Grigore, L. (2001) Preparation and Evaluation of potassium Ferrate as an Oxidant and Coagulant for Potable Water Treatment. Environmental Engineering Science, 18, 323-328. 
Jiang, J. Q.; Lloyd, B. (2002) Progress in the Development and Use of Ferrate (VI) Salt as an Oxidant and Coagulant for Water and Wastewater Treatment. Water Research, 36, 1397-1408.

Jiang, J. Q.; Panagoulopoulos, A.; Bauer, M.; Pearce, P. (2006) The Application of Potassium Ferrate for Sewage Treatment. Journal of Environmental Management, 79, 215-220.

Jiang, J. Q.; Zhou, Z.; Pahl, O. (2012) Preliminary Study of Ciprofloxacin (CIP) Removal by Potassium Ferrate (VI). Separation and Purification Technology, 88, 95-98.

Jin, Y.; You, X. Y.; Ji, M. (2013) On Intensive Process of Quantity and Quality Improvement of Wastewater Treatment Plant Under Rainfall Conditions. Desalination and Water Treatment, (ahead-of-print), 1-10.

Jolis, D.; Ahmad, M. L. (2004) Evaluation of High-Rate Clarification for Wet-WeatherOnly Treatment Facilities. Water Environment Research, 474-480.

Kokarovtseva, I. G.; Belyaev, I. N.; Semenyakova, L. V. (1972) Oxygen Compounds of Iron (VI, V, IV). Russian Chemical Reviews, 41, 929-937.

Kopelev, N. S.; Perfiliev, Y. D.; Kiselev, Y. M. (1992) Mössbauer Study of Sodium Ferrates (IV) and (VI). Journal of Radioanalytical and Nuclear chemistry, 162, 239-251.

Lee, Y.; Yoon, J.; Von Gunten, U. (2005) Kinetics of the Oxidation of Phenols and Phenolic Endocrine Disruptors during Water Treatment with Ferrate (Fe (VI)). Environmental Science \& Technology, 39, 8978-8984. 
Lescuras-Darrou, V. M. W. Y.; Lapicque, F.; Valentin, G. (2002) Electrochemical Ferrate Generation for Wastewater Treatment Using Cast Irons with High Silicon Contents. Journal of Applied Electrochemistry, 32, 57-63.

Landon, S.; Donahue, C.; Jeyanayagam, S.; Cruden, D. (2006) Rain check. Water Environment \& Technology, 18, 30-35.

Lee, C.; Lee, Y.; Schmidt, C.; Yoon, J.; Von Gunten, U. (2008) Oxidation of Suspected N-Nitrosodimethylamine (NDMA) Precursors by Ferrate (VI): Kinetics and Effect on the NDMA Formation Potential of Natural Waters. Water Research, 42, 433-441.

Metcalf \& Eddy, Inc. (2003) Wastewater Engineering: Treatment and Reuse, 4th ed.; Mc Graw-Hill: New York.

Ministry of the Environment. Determination of Treatment Requirements for Municipal and Private Combined and Partially Separated Sewer Systems. Procedure F-5-5. (www.ene.gov.on.ca/envision/gp/F5-5.pdf).

Norcross, B. E.; Lewis, W. C.; Gai, H.; Noureldin, N. A.; Lee, D. G. (1997) The Oxidation of Secondary Alcohols by Potassium Tetraoxoferrate (VI). Canadian Journal of Chemistry, 75, 129-139.

Patterson, J. W.; Kodukula, P. S. (1984) Metals Distributions In Activated Sludge Systems. Journal (Water Pollution Control Federation), 432-441.

Perkowski, J.; Kos, L. (2002) Treatment of Textile Dyeing Wastewater by Hydrogen Peroxide and Ferrous Ions. Fibres and Textiles in Eastern Europe, 10, 78-81. 
Plum, V.; Dahl, C. P.; Bentsen, L.; Petersen, C. R.; Napstjert, L.; Thomsen, N. B. (1998) The Actiflo Method. Water Science and Technology, 37, 269-275.

Sharma, V. K. (2002) Potassium ferrate (VI): An Environmentally Friendly Oxidant. Advances in Environmental Research, 6, 143-156.

Sharma, V.; Kazama, F.; Jiangyong, H.; Ray, A. (2005) Ferrates (Iron (VI) and Iron (V)): Environmentally Friendly Oxidants and Disinfectants. Journal of Water Health, 3, 45-58.

Sharma, V. K.; Mishra, S. K. (2006) Ferrate (VI) Oxidation of Ibuprofen: A Kinetic Study. Environmental Chemistry Letters, 3, 182-185.

Sharma, V. (2007) Disinfection Performance of Fe (VI) in Water and Wastewater: A Review. Water Science \& Technology, 55, 225-232.

Sharma, V. K.; Noorhasan, N. N.; Mishra, S. K.; Nesnas, N. (2008) Ferrate (VI) Oxidation of Recalcitrant Compounds: Removal of Biological Resistant Organic Molecules by Ferrate (VI). In Ferrates: Synthesis, Properties, and Applications in Water and Wastewater Treatment; ACS Symposium Series; American Chemical Society; Washington, DC, pp 339-349.

Stanford, C.; Jiang, J. Q.; Alsheyab, M. (2010) Electrochemical Production of Ferrate (Iron VI): Application to the Wastewater Treatment on a Laboratory Scale and Comparison with Iron (III) Coagulant. Water, Air, \& Soil Pollution, 209, 483-488.

Sharma, V. K.; Sohn, M.; Anquandah, G. A.; Nesnas, N. (2012) Kinetics of the Oxidation of Sucralose and Related Carbohydrates by Ferrate (VI). Chemosphere, 87, 644-648. 
Thompson, G. W.; Ockerman, L. T.; Schreyer, J. M. (1951) Preparation and Purification of Potassium Ferrate (VI). Journal of the American Chemical Society, 73, 1379-1381.

Tiwari, D.; Yang, J.; Lee, S. (2005) Applications of Ferrate (VI) in the Treatment of Wastewaters. Environmental Engineering Research, 10, 269-282.

US Environmental Protection Agency (2003) Wastewater Technology Fact Sheet: Ballasted Flocculation; EPA 832-F-03-010; Washington, D.C.

US Environmental Protection Agency (2013) Emerging Technologies for Wastewater Treatment and In-Plant Wet Weather Management; EPA 832-R-12-011; Washington, D.C.

Vance, D. B. (1994) Iron - The Environmental Impact of the Universal Element. National Environmental Journal, 4, 24-25.

White, D. A.; Franklin, G. S. (1998) A Preliminary Investigation into the Use of Sodium Ferrate in Water Treatment. Environmental Technology, 19, 1157-1161.

Yang, B.; Ying, G. G.; Zhang, L. J.; Zhou, L. J.; Liu, S.; Fang, Y. X. (2011) Kinetics Modeling and Reaction Mechanism of Ferrate (VI) Oxidation of Benzotriazoles. Water Research, 45, 2261-2269. 


\section{Chapter 4}

\section{Conclusions and Recommendations}

\subsection{Conclusions}

- Ferrate (VI) proved to be an efficient chemical for treatment of CSOs. Very low dose of commercial Fe (VI) i.e. $0.24 \mathrm{mg} / \mathrm{l}$, achieved $75 \%, 68 \%, 64 \%, 38 \%$ and $36 \%$ removal of $\mathrm{SCOD}, \mathrm{SBOD}_{5}, \mathrm{TP}, \mathrm{TN}$ and $\mathrm{STN}$ respectively within a contact time of only $15 \mathrm{~min}$.

- Ferrate (VI) was successfully synthesized from filtered digested biosolids, an insitu iron source as well as from $\mathrm{FeSO}_{4} \cdot 7 \mathrm{H}_{2} \mathrm{O}$, a pure iron source.

- Ferrate (VI) synthesized from digested PS filtrate was found out to be more effective than the Fe (VI) generated from digested TWAS filtrate, digested PS, digested TWAS.

- At the optimum, filtered digested PS synthesized Fe (VI) dose of $0.1 \mathrm{mg} / \mathrm{l}$; SCOD, $\mathrm{TP}$ and $\mathrm{TN}$ removal efficiencies of $62 \%, 30 \%$ and $25 \%$ respectively were achieved.

- Treatment efficiencies achieved by Fe (VI) synthesized from dig PS sludge were comparable to those achieved by $\mathrm{Fe}(\mathrm{VI})$ synthesized from $\mathrm{FeSO}_{4} \cdot 7 \mathrm{H}_{2} \mathrm{O}$.

- The removal efficiencies achieved by Fe (VI) produced from digested PS and digested TWAS were inferior to those achieved by respective control $\mathrm{NaOCl}$ dose. Thus, practically, digested PS and digested TWAS cannot be used for generation of $\mathrm{Fe}(\mathrm{VI})$. 
- The treated CSOs water quality characteristics achieved by Fe (VI) treatment were comparable to the secondary effluent water characteristics proposed by Ontario MOE and USEPA.

The low dose, short contact time, attainment of secondary effluent characteristics, no start up time, and the removal of soluble organics, nitrogen and phosphorous are the most salient advantages of ferrate (VI) treatment.

\subsection{Recommendations}

Based on results presented, few issues need to be addressed. Following is the list of the future work that can be done to address these issues:

- The contact time of 15 minutes was calculated, which includes 5 minutes of mixing and 10 minutes of settling. With reference to figure 3.4, it can be pointed out that, in case of continuous mixing contact time of Ferrate (VI) can be expected to be less than 15 min. Thus, detailed kinetic study of Fe (VI) treatment needs to be done in order to find out the precise contact time of Fe (VI).

- Evaluation of Fe (VI) performance on the continuous CSO system, by setting up the pilot scale CSO treatment plant should be done in order to calculate the real time optimum Fe (VI) dose.

- The Fe (VI) synthesized from digested filtrate achieved high removal efficiency. This points out that, Fe (VI) can be generated from filtered dewatering filtrate and can be more efficient and cost effective. Thus, Fe (VI) synthesis should be tried using various in-situ iron sources. 
- Treatment efficiencies achieved by $0.1 \mathrm{mg}$ Fe (VI)/l synthesized from digested PS filtrate were comparable to those obtained from $0.49 \mathrm{mg}$ Fe (VI)/l produced from $\mathrm{FeSO}_{4} \cdot 7 \mathrm{H}_{2} \mathrm{O}$ (a pure iron source). Thus, characterization of the filtered biosolids synthesized Fe (VI) sample should be done in order to check the various compounds produced simultaneously with the Fe (VI), which can further act as an oxidant or coagulant.

- Impact of $\mathrm{pH}$ and oxidizing agents on the synthesis of ferrate (VI) should be studied in order to get pure and stable ferrate (VI).

- Modeling of the ferrate (VI) synthesis and treatment technology should be done.

- Cost analysis of Fe (VI) treatment method and its comparison with the established physical chemical treatment process should be carried out.

All these can lead to a more exhaustive study about the CSOs treatment using Fe (VI). 


\section{Appendices}

\section{Appendix A: Applicability of Fe (VI) for CSO treatment (Raw Data)}

Table A1: Run 1 (Jar Test)

\begin{tabular}{|c|c|c|c|c|c|c|c|c|}
\hline $\begin{array}{l}\mathrm{Fe}(\mathrm{VI}) \\
\text { Dose(mg/l) }\end{array}$ & W1 & $\mathrm{W} 2$ & W3 & $\begin{array}{l}\text { W2- } \\
\text { W1 }\end{array}$ & $\begin{array}{l}\text { W2- } \\
\text { W3 }\end{array}$ & $\begin{array}{c}\text { Volume } \\
(\mathrm{ml})\end{array}$ & $\begin{array}{c}\text { TSS } \\
(\mathrm{mg} / \mathrm{l})\end{array}$ & $\begin{array}{c}\text { VSS } \\
(\mathrm{mg} / \mathrm{l})\end{array}$ \\
\hline RWW & 1.4466 & 1.4532 & 1.448 & 0.0066 & 0.0052 & 20 & 330 & 260 \\
\hline $\mathrm{CSO}$ & 1.4417 & 1.444 & 1.4421 & 0.0023 & 0.0019 & 20 & 115 & 95 \\
\hline 0 & 1.4524 & 1.454 & 1.4526 & 0.0016 & 0.0014 & 20 & 80 & 70 \\
\hline 0.3 & 1.4439 & 1.4444 & 1.444 & 0.0005 & 0.0004 & 20 & 25 & 20 \\
\hline 0.6 & 1.4471 & 1.4476 & 1.4474 & 0.0005 & 0.0002 & 20 & 25 & 10 \\
\hline 1.5 & 1.45 & 1.4509 & 1.4507 & 0.0009 & 0.0002 & 20 & 45 & 10 \\
\hline 15 & 1.4449 & 1.4458 & 1.4453 & 0.0009 & 0.0005 & 20 & 45 & 25 \\
\hline 30 & 1.4508 & 1.4517 & 1.4513 & 0.0009 & 0.0004 & 20 & 45 & 20 \\
\hline
\end{tabular}

\begin{tabular}{|c|c|c|c|c|c|}
\hline $\begin{array}{c}\text { Fe (VI) Dose } \\
(\mathbf{m g} / \mathbf{l})\end{array}$ & TCOD & $\begin{array}{c}\text { SCOD } \\
(\mathbf{m g} / \mathbf{l})\end{array}$ & $\begin{array}{c}\text { TSS } \\
(\mathbf{m g} / \mathbf{l})\end{array}$ & $\begin{array}{c}\text { VSS } \\
(\mathbf{m g} / \mathbf{l})\end{array}$ \\
\hline & RWW & 350 & 168 & 330 & 260 \\
\hline & CSO & 114 & 58 & 115 & 95 \\
\hline $\mathbf{0}$ & Jar Test 1 & 81 & 46 & 80 & 70 \\
\hline $\mathbf{0 . 3}$ & Jar Test 2 & 14 & 14 & 25 & 20 \\
\hline $\mathbf{0 . 6}$ & Jar Test 3 & 25 & 19 & 25 & 10 \\
\hline $\mathbf{1 . 5}$ & Jar Test 4 & 33 & 41 & 45 & 10 \\
\hline $\mathbf{1 5}$ & Jar Test 5 & 37 & 47 & 45 & 25 \\
\hline $\mathbf{3 0}$ & Jar Test 6 & 57 & 41 & 45 & 20 \\
\hline
\end{tabular}

\begin{tabular}{|c|c|c|c|c|}
\hline Fe (VI) Dose (mg/l) & \multicolumn{5}{|c|}{ \% Removal } \\
\hline & TCOD & SCOD & TSS & VSS \\
\hline $\mathbf{0}$ & 29 & 21 & 30 & 26 \\
\hline $\mathbf{0 . 3}$ & 88 & 76 & 78 & 79 \\
\hline $\mathbf{0 . 6}$ & 78 & 68 & 78 & 89 \\
\hline $\mathbf{1 . 5}$ & 71 & 30 & 61 & 89 \\
\hline $\mathbf{1 5}$ & 68 & 19 & 61 & 74 \\
\hline $\mathbf{3 0}$ & 50 & 29 & 61 & 79 \\
\hline
\end{tabular}


Table A2: Run 2 (Jar Test)

\begin{tabular}{|c|c|c|c|c|}
\hline $\begin{array}{c}\text { Fe (VI) Dose } \\
(\mathbf{m g} / \mathbf{l})\end{array}$ & $\begin{array}{c}\text { TCOD } \\
(\mathbf{m g} / \mathbf{l})\end{array}$ & $\begin{array}{c}\text { SCOD } \\
(\mathbf{m g} / \mathbf{l})\end{array}$ & TSS (mg/l) & $\begin{array}{c}\text { VSS } \\
(\mathbf{m g} / \mathbf{l})\end{array}$ \\
\hline & 114 & 58 & 115 & 95 \\
\hline $\mathbf{0}$ & 81 & 48 & 80 & 70 \\
\hline $\mathbf{0 . 3}$ & 29 & 17 & 35 & 20 \\
\hline $\mathbf{0 . 6}$ & 29 & 19 & 30 & 0 \\
\hline $\mathbf{1 . 5}$ & 36 & 42 & 35 & 20 \\
\hline $\mathbf{1 5}$ & 48 & 50 & 70 & 15 \\
\hline $\mathbf{3 0}$ & 40 & 44 & 50 & 15 \\
\hline
\end{tabular}

\begin{tabular}{|c|c|c|c|c|}
\hline $\begin{array}{c}\text { Fe (VI) Dose } \\
(\mathbf{m g} / \mathbf{l})\end{array}$ & \multicolumn{4}{|c|}{ \% Removal } \\
\hline & TCOD & SCOD & TSS & VSS \\
\hline $\mathbf{0}$ & 29 & 17 & 30 & 26 \\
\hline $\mathbf{0 . 3}$ & 75 & 71 & 70 & 79 \\
\hline $\mathbf{0 . 6}$ & 75 & 68 & 74 & 100 \\
\hline $\mathbf{1 . 5}$ & 68 & 27 & 70 & 79 \\
\hline $\mathbf{1 5}$ & 58 & 14 & 39 & 84 \\
\hline $\mathbf{3 0}$ & 65 & 25 & 57 & 84 \\
\hline
\end{tabular}

Table A3: Run 3 (Jar Test)

\begin{tabular}{|c|c|c|c|c|c|}
\hline $\begin{array}{c}\text { Fe (VI) Dose } \\
(\mathbf{m g} / \mathbf{l})\end{array}$ & & $\begin{array}{c}\text { TCOD } \\
(\mathbf{m g} / \mathbf{l})\end{array}$ & $\begin{array}{c}\text { SCOD } \\
(\mathbf{m g} / \mathbf{l})\end{array}$ & $\begin{array}{c}\text { TSS } \\
(\mathbf{m g} / \mathbf{l})\end{array}$ & $\begin{array}{c}\text { VSS } \\
(\mathbf{m g} / \mathbf{l})\end{array}$ \\
\hline & CSO & 114 & 58 & 115 & 95 \\
\hline $\mathbf{0}$ & Jar Test 1 & 88 & 47 & 80 & 70 \\
\hline $\mathbf{0 . 3}$ & Jar Test 2 & 16 & 17 & 45 & 35 \\
\hline $\mathbf{0 . 6}$ & Jar Test 3 & 25 & 15 & 20 & 5 \\
\hline $\mathbf{1 . 5}$ & Jar Test 4 & 47 & 51 & 40 & 15 \\
\hline $\mathbf{1 5}$ & Jar Test 5 & 46 & 44 & 65 & 20 \\
\hline $\mathbf{3 0}$ & Jar Test 6 & 40 & 25 & 55 & 10 \\
\hline
\end{tabular}




\begin{tabular}{|c|r|r|r|r|}
\hline $\begin{array}{c}\text { Fe (VI) Dose } \\
(\mathbf{m g} / \mathbf{l})\end{array}$ & \multicolumn{5}{|c|}{ \% Removal } \\
\hline & TCOD & \multicolumn{1}{|c|}{ SCOD } & \multicolumn{1}{c|}{ TSS } & \multicolumn{1}{c|}{ VSS } \\
\hline $\mathbf{0}$ & 23 & 19 & 30 & 26 \\
\hline $\mathbf{0 . 3}$ & 86 & 71 & 61 & 63 \\
\hline $\mathbf{0 . 6}$ & 78 & 74 & 83 & 95 \\
\hline $\mathbf{1 . 5}$ & 59 & 12 & 65 & 84 \\
\hline $\mathbf{1 5}$ & 60 & 24 & 43 & 79 \\
\hline $\mathbf{3 0}$ & 65 & 57 & 52 & 89 \\
\hline
\end{tabular}

Table A4: Data used for Figure 3.1 (Average of all runs)

\begin{tabular}{|c|c|c|c|c|c|}
\hline $\begin{array}{c}\text { Fe (VI) Dose } \\
(\mathbf{m g} / \mathbf{l})\end{array}$ & $\begin{array}{c}\text { TCOD } \\
(\mathbf{m g} / \mathbf{l})\end{array}$ & $\begin{array}{c}\text { SCOD } \\
(\mathbf{m g} / \mathbf{l})\end{array}$ & $\begin{array}{c}\text { TSS } \\
(\mathbf{m g} / \mathbf{l})\end{array}$ & $\begin{array}{c}\text { VSS } \\
(\mathbf{m g} / \mathbf{l})\end{array}$ \\
\hline & CSO & 114 & 58 & 115 & 95 \\
\hline $\mathbf{0}$ & Jar Test 1 & 83 & 47 & 80 & 70 \\
\hline $\mathbf{0 . 3}$ & Jar Test 2 & 19 & 16 & 35 & 25 \\
\hline $\mathbf{0 . 6}$ & Jar Test 3 & 26 & 17 & 25 & 5 \\
\hline $\mathbf{1 . 5}$ & Jar Test 4 & 39 & 45 & 40 & 15 \\
\hline $\mathbf{1 5}$ & Jar Test 5 & 43 & 47 & 60 & 20 \\
\hline $\mathbf{3 0}$ & Jar Test 6 & 46 & 37 & 50 & 15 \\
\hline
\end{tabular}

\begin{tabular}{|c|c|c|c|c|}
\hline $\begin{array}{c}\text { Fe (VI) Dose } \\
(\mathbf{m g} / \mathbf{l})\end{array}$ & \multicolumn{4}{|c|}{ \% Removal } \\
\hline & TCOD & SCOD & TSS & VSS \\
\hline $\mathbf{0}$ & 27 & 19 & 30 & 26 \\
\hline $\mathbf{0 . 3}$ & 83 & 73 & 70 & 74 \\
\hline $\mathbf{0 . 6}$ & 77 & 70 & 78 & 95 \\
\hline $\mathbf{1 . 5}$ & 66 & 23 & 65 & 84 \\
\hline $\mathbf{1 5}$ & 62 & 19 & 48 & 79 \\
\hline $\mathbf{3 0}$ & 60 & 37 & 57 & 84 \\
\hline
\end{tabular}


Appendix B: Optimization of Fe (VI) dose (Data used for Figure 3.2)

Table B1: pH 6

\begin{tabular}{|c|c|c|c|c|c|c|}
\hline $\begin{array}{c}\text { Fe (VI)Dose } \\
(\mathbf{m g} / \mathbf{l})\end{array}$ & TSS (mg/l) & VSS (mg/l) & $\begin{array}{c}\text { TCOD } \\
(\mathbf{m g} / \mathbf{l})\end{array}$ & $\begin{array}{c}\text { SCOD } \\
(\mathbf{m g} / \mathbf{l})\end{array}$ & $\begin{array}{c}\text { TN } \\
(\mathbf{m g} / \mathbf{l})\end{array}$ & TP(mg/l) \\
\hline $\mathrm{RWW}$ & 210 & 190 & 292 & 132 & 29 & 6.4 \\
\hline $\mathrm{CSO}$ & 70 & 60 & 90 & 48 & 8.9 & 2.5 \\
\hline 0 & 50 & 40 & 64 & 36 & 8.7 & 2.2 \\
\hline 0.12 & 40 & 30 & 56 & 30 & 7.9 & 1.8 \\
\hline 0.24 & 40 & 30 & 51 & 27 & 7.5 & 1.6 \\
\hline 0.36 & 30 & 20 & 54 & 30 & 7.7 & 1.8 \\
\hline 0.48 & 30 & 30 & 47 & 27 & 7.6 & 1.7 \\
\hline 0.6 & 30 & 0 & 43 & 24 & 7 & 1.5 \\
\hline
\end{tabular}

\begin{tabular}{|c|c|c|c|c|c|c|}
\hline $\begin{array}{c}\text { Fe (VI)Dose } \\
\text { (mg/I) }\end{array}$ & \multicolumn{7}{|c|}{ \% Removal } \\
\hline & TSS & VSS & TCOD & SCOD & TN & TP \\
\hline 0 & 29 & 33 & 29 & 25 & 2 & 12 \\
\hline 0.12 & 43 & 50 & 38 & 38 & 11 & 28 \\
\hline 0.24 & 43 & 50 & 43 & 44 & 16 & 36 \\
\hline 0.36 & 57 & 67 & 40 & 38 & 13 & 28 \\
\hline 0.48 & 57 & 50 & 48 & 44 & 15 & 32 \\
\hline 0.6 & 57 & 100 & 52 & 25 & 21 & 40 \\
\hline
\end{tabular}

Table B2: pH 7

\begin{tabular}{|c|c|c|c|c|c|c|}
\hline $\begin{array}{c}\text { Fe (VI)Dose } \\
(\mathbf{m g} / \mathbf{l})\end{array}$ & TSS (mg/l) & VSS (mg/l) & $\begin{array}{c}\text { TCOD } \\
(\mathbf{m g} / \mathbf{l})\end{array}$ & $\begin{array}{c}\text { SCOD } \\
(\mathbf{m g} / \mathbf{l})\end{array}$ & $\begin{array}{c}\text { TN } \\
(\mathbf{m g} / \mathbf{l})\end{array}$ & TP(mg/l) \\
\hline CSO & 70 & 60 & 90 & 48 & 8.9 & 2.5 \\
\hline 0 & 50 & 50 & 67 & 33 & 8.7 & 2.3 \\
\hline 0.12 & 40 & 20 & 41 & 24 & 6.4 & 1.7 \\
\hline 0.24 & 30 & 20 & 28 & 15 & 5.5 & 1.2 \\
\hline 0.36 & 30 & 30 & 32 & 18 & 6.1 & 1.7 \\
\hline 0.48 & 30 & 10 & 34 & 27 & 5.9 & 1.6 \\
\hline 0.6 & 20 & 10 & 32 & 18 & 5.6 & 1.3 \\
\hline
\end{tabular}




\begin{tabular}{|c|c|c|c|c|c|c|}
\hline $\begin{array}{c}\text { Fe (VI)Dose } \\
(\mathbf{m g} / \text { I) }\end{array}$ & \multicolumn{7}{|c|}{ \% Removal } \\
\hline & TSS & VSS & TCOD & SCOD & TN & TP \\
\hline 0 & 29 & 16 & 26 & 31 & 2 & 8 \\
\hline 0.12 & 43 & 67 & 54 & 50 & 28 & 32 \\
\hline 0.24 & 57 & 67 & 69 & 69 & 38 & 52 \\
\hline 0.36 & 57 & 50 & 64 & 63 & 31 & 32 \\
\hline 0.48 & 57 & 83 & 62 & 44 & 34 & 36 \\
\hline 0.6 & 71 & 83 & 64 & 63 & 37 & 48 \\
\hline
\end{tabular}

Table B3: pH 8

\begin{tabular}{|c|c|c|c|c|c|r|}
\hline $\begin{array}{c}\text { Fe (VI)Dose } \\
(\mathbf{m g} / \mathbf{l})\end{array}$ & TSS (mg/l) & VSS (mg/l) & $\begin{array}{c}\text { TCOD } \\
(\mathbf{m g} / \mathbf{l})\end{array}$ & $\begin{array}{c}\text { SCOD } \\
(\mathbf{m g} / \mathbf{l})\end{array}$ & $\begin{array}{c}\text { TN } \\
(\mathbf{m g} / \mathbf{l})\end{array}$ & TP(mg/l) \\
\hline CSO & 70 & 60 & 90 & 48 & 8.9 & 2.5 \\
\hline 0 & 50 & 40 & 62 & 37 & 8.5 & 2.3 \\
\hline 0.12 & 40 & 20 & 43 & 30 & 7.1 & 1.7 \\
\hline 0.24 & 20 & 20 & 28 & 18 & 6.1 & 1.1 \\
\hline 0.36 & 30 & 10 & 26 & 12 & 5.7 & 1.6 \\
\hline 0.48 & 30 & 10 & 37 & 24 & 5.9 & 1.6 \\
\hline 0.6 & 20 & 0 & 35 & 12 & 5.4 & 1.3 \\
\hline
\end{tabular}

\begin{tabular}{|c|c|c|c|c|c|c|}
\hline $\begin{array}{c}\text { Fe (VI)Dose } \\
(\mathbf{m g} / \text { /) }\end{array}$ & \multicolumn{7}{|c|}{ \% Removal } \\
\hline & TSS & VSS & TCOD & SCOD & TN & TP \\
\hline 0 & 29 & 33 & 31 & 23 & 4 & 8 \\
\hline 0.12 & 43 & 67 & 52 & 38 & 20 & 32 \\
\hline 0.24 & 71 & 67 & 69 & 63 & 31 & 56 \\
\hline 0.36 & 57 & 83 & 71 & 62.5 & 36 & 36 \\
\hline 0.48 & 57 & 83 & 59 & 25 & 34 & 36 \\
\hline 0.6 & 71 & 100 & 61 & 62.5 & 39 & 48 \\
\hline
\end{tabular}


Table B4: pH 9

\begin{tabular}{|c|c|c|c|c|c|c|}
\hline $\begin{array}{c}\text { Fe (VI)Dose } \\
(\mathbf{m g} / \mathbf{l})\end{array}$ & TSS (mg/l) & VSS (mg/l) & $\begin{array}{c}\text { TCOD } \\
(\mathbf{m g} / \mathbf{l})\end{array}$ & $\begin{array}{c}\text { SCOD } \\
(\mathbf{m g} / \mathbf{l})\end{array}$ & $\begin{array}{c}\text { TN } \\
(\mathbf{m g} / \mathbf{l})\end{array}$ & TP(mg/l) \\
\hline CSO & 70 & 60 & 90 & 48 & 8.9 & 2.5 \\
\hline 0 & 50 & 40 & 62 & 39 & 8.8 & 2.2 \\
\hline 0.12 & 30 & 20 & 17 & 9 & 6.4 & 1.2 \\
\hline 0.24 & 10 & 0 & 19 & 15 & 5.2 & 1 \\
\hline 0.36 & 20 & 20 & 22 & 15 & 6.1 & 0.8 \\
\hline 0.48 & 20 & 10 & 26 & 12 & 5.9 & 0.8 \\
\hline 0.6 & 20 & 10 & 19 & 15 & 5.4 & 0.9 \\
\hline
\end{tabular}

\begin{tabular}{|c|c|c|c|c|c|c|}
\hline $\begin{array}{c}\text { Fe (VI)Dose } \\
(\mathbf{m g} / \mathbf{l})\end{array}$ & \multicolumn{7}{|c|}{ \% Removal } \\
\hline & TSS & VSS & TCOD & SCOD & TN & TP \\
\hline 0 & 29 & 33 & 31 & 19 & 1 & 12 \\
\hline 0.12 & 57 & 67 & 81 & 81 & 28 & 52 \\
\hline 0.24 & 86 & 100 & 79 & 69 & 41 & 60 \\
\hline 0.36 & 71 & 67 & 76 & 69 & 31 & 68 \\
\hline 0.48 & 71 & 83 & 71 & 75 & 34 & 68 \\
\hline 0.6 & 71 & 83 & 79 & 69 & 39 & 64 \\
\hline
\end{tabular}


Appendix C: Kinetics (Data used for Figure 3.4)

Table C1 (Neutral pH; Dose: 0.24 mg Fe (VI)/l)

\begin{tabular}{|c|c|c|c|c|c|c|c|c|}
\hline $\begin{array}{c}\text { Time } \\
(\mathbf{m i n})\end{array}$ & $\begin{array}{c}\text { TSS } \\
(\mathbf{m g} / \mathbf{l})\end{array}$ & $\begin{array}{c}\text { VSS } \\
(\mathbf{m g} / \mathbf{l})\end{array}$ & $\begin{array}{c}\text { TCOD } \\
(\mathbf{m g} / \mathbf{l})\end{array}$ & $\begin{array}{c}\text { SCOD } \\
(\mathbf{m g} / \mathbf{l})\end{array}$ & $\begin{array}{c}\text { PCOD } \\
(\mathbf{m g} / \mathbf{l})\end{array}$ & $\begin{array}{c}\text { TBOD } \\
(\mathbf{m g} / \mathbf{l})\end{array}$ & $\begin{array}{c}\text { SBOD } \\
(\mathbf{m g} / \mathbf{l})\end{array}$ & $\begin{array}{c}\text { PBOD } \\
(\mathbf{m g} / \mathbf{l})\end{array}$ \\
\hline $\mathrm{RWW}$ & 190 & 170 & 284 & 90 & 194 & 163.6 & 50 & 113.6 \\
\hline $\mathrm{CSO}$ & 70 & 60 & 84 & 32 & 52 & 50.6 & 17.9 & 32.7 \\
\hline 1 & 60 & 60 & 80 & 28 & 52 & 50.1 & 17.4 & 32.7 \\
\hline 2 & 50 & 50 & 74 & 26 & 48 & 44.4 & 15.2 & 29.2 \\
\hline 3 & 40 & 40 & 54 & 22 & 32 & 32.6 & 14.1 & 18.5 \\
\hline 4 & 50 & 30 & 46 & 22 & 24 & 29.7 & 14.5 & 15.2 \\
\hline 5 & 30 & 40 & 44 & 16 & 28 & 26.9 & 10.2 & 16.7 \\
\hline 10 & 40 & 20 & 30 & 10 & 20 & 19.3 & 6.9 & 12.4 \\
\hline 15 & 30 & 20 & 26 & 8 & 18 & 15.4 & 5.3 & 10.1 \\
\hline 20 & 20 & 20 & 26 & 8 & 18 & 16.2 & 4.9 & 11.3 \\
\hline 40 & 30 & 20 & 24 & 8 & 16 & 15.7 & 5.5 & 10.2 \\
\hline
\end{tabular}

\begin{tabular}{|c|c|c|c|c|c|c|}
\hline $\begin{array}{c}\text { Time } \\
(\mathbf{m i n})\end{array}$ & $\begin{array}{c}\text { NH4 } \\
(\mathbf{m g} / \mathbf{l})\end{array}$ & $\begin{array}{c}\text { TN } \\
(\mathbf{m g} / \mathbf{l})\end{array}$ & $\begin{array}{c}\text { STN } \\
(\mathbf{m g} / \mathbf{l})\end{array}$ & $\begin{array}{c}\text { org N } \\
(\mathbf{m g} / \mathbf{l})\end{array}$ & $\begin{array}{c}\text { TP } \\
(\mathbf{m g} / \mathbf{l})\end{array}$ & $\begin{array}{c}\text { PO43- } \\
(\mathbf{m g} / \mathbf{l})\end{array}$ \\
\hline RWW & 13.8 & 26 & 18.7 & 4.9 & 6 & 3.4 \\
\hline CSO & 4.9 & 9 & 7.4 & 2.5 & 2.5 & 1.1 \\
\hline 1 & 4.6 & 8.6 & 7.2 & 2.5 & 2.4 & 1 \\
\hline 2 & 4.6 & 8.3 & 6.7 & 2.1 & 2.4 & 1.1 \\
\hline 3 & 4.5 & 8 & 6.6 & 1.8 & 2.3 & 1 \\
\hline 4 & 4.6 & 7.4 & 6.3 & 1.8 & 2.1 & 1.1 \\
\hline 5 & 4.3 & 7.1 & 6 & 1.5 & 1.7 & 1 \\
\hline 10 & 4.4 & 6.6 & 5.8 & 1.1 & 1.3 & 0.9 \\
\hline 15 & 4.4 & 5.9 & 5 & 0.8 & 1.1 & 0.8 \\
\hline 20 & 4.3 & 5.9 & 5 & 0.7 & 1.1 & 0.9 \\
\hline 40 & 4.3 & 5.9 & 4.9 & 0.6 & 1 & 0.8 \\
\hline
\end{tabular}




\begin{tabular}{|c|c|c|c|c|c|c|c|c|}
\cline { 2 - 10 } \multicolumn{1}{c|}{} & \multicolumn{9}{c|}{ \% Removal } & & \\
\hline $\begin{array}{c}\text { Time } \\
(\mathbf{m i n})\end{array}$ & TCOD & SCOD & TBOD & SBOD & TSS & VSS & PCOD & PBOD \\
\hline 1 & 5 & 13 & 1 & 3 & 14 & 0 & 0 & 0 \\
\hline 2 & 12 & 19 & 12 & 15 & 26 & 17 & 8 & 11 \\
\hline 3 & 36 & 31 & 36 & 21 & 43 & 33 & 38 & 43 \\
\hline 4 & 45 & 31 & 41 & 19 & 29 & 50 & 54 & 54 \\
\hline 5 & 48 & 50 & 47 & 43 & 57 & 33 & 46 & 49 \\
\hline 10 & 64 & 69 & 62 & 61 & 43 & 67 & 62 & 62 \\
\hline 15 & 69 & 75 & 69 & 70 & 57 & 67 & 65 & 69 \\
\hline 20 & 69 & 75 & 68 & 73 & 71 & 67 & 65 & 65 \\
\hline 40 & 71 & 75 & 69 & 69 & 57 & 67 & 69 & 69 \\
\hline
\end{tabular}

\begin{tabular}{|c|c|c|c|c|c|c|}
\cline { 2 - 7 } \multicolumn{1}{c|}{} & \multicolumn{6}{c|}{ \% Removal } \\
\hline $\begin{array}{c}\text { Time } \\
(\mathbf{m i n})\end{array}$ & NH4 & TN & STN & org N & TP & PO43- \\
\hline 1 & 6 & 4 & 3 & 0 & 4 & 9 \\
\hline 2 & 6 & 8 & 9 & 16 & 4 & 0 \\
\hline 3 & 8 & 11 & 11 & 28 & 8 & 9 \\
\hline 4 & 6 & 18 & 15 & 28 & 16 & 0 \\
\hline 5 & 12 & 21 & 19 & 40 & 32 & 9 \\
\hline 10 & 10 & 26 & 22 & 56 & 48 & 18 \\
\hline 15 & 10 & 34 & 32 & 68 & 56 & 27 \\
\hline 20 & 12 & 34 & 32 & 72 & 56 & 18 \\
\hline 40 & 12 & 34 & 34 & 76 & 60 & 27 \\
\hline
\end{tabular}


Appendix D: Performance of Fe (VI) synthesized from various doses (Data used for Figure 3.6)

\begin{tabular}{|c|c|c|c|c|c|c|}
\hline & Ferrate Source & FeSO4.7H2O & Dig PS & Dig PS filt & Dig TWAS & $\begin{array}{l}\text { Dig TWAS } \\
\text { Filt }\end{array}$ \\
\hline & Dose (mg/l) & 0.49 & 0.72 & 0.1 & 0.27 & 0.09 \\
\hline \multirow{2}{*}{$\begin{array}{c}\text { TCOD } \\
(\mathbf{m g} / \mathbf{l})\end{array}$} & Influent TCOD & 98 & 122 & 106 & 112 & 104 \\
\hline & Effluent TCOD & 36 & 84 & 42 & 74 & 60 \\
\hline \multirow{2}{*}{$\begin{array}{l}\text { SCOD } \\
(\mathbf{m g} / \mathbf{l})\end{array}$} & Influent SCOD & 36 & 44 & 40 & 40 & 38 \\
\hline & Effluent SCOD & 13 & 30 & 16 & 30 & 23 \\
\hline \multirow{2}{*}{$\begin{array}{c}\text { TSS } \\
(\mathrm{mg} / \mathrm{l})\end{array}$} & Influent TSS & 70 & 100 & 70 & 90 & 70 \\
\hline & Effluent TSS & 20 & 70 & 30 & 60 & 40 \\
\hline \multirow{2}{*}{$\begin{array}{c}\text { VSS } \\
(\mathrm{mg} / \mathrm{l})\end{array}$} & Influent VSS & 60 & 80 & 60 & 80 & 60 \\
\hline & Effluent VSS & 10 & 60 & 20 & 50 & 30 \\
\hline \multirow{2}{*}{$\begin{array}{l}\mathrm{TBOD}_{5} \\
(\mathbf{m g} / \mathbf{l})\end{array}$} & Influent $\mathrm{TBOD}_{5}$ & 63 & 81.2 & 64.9 & 65.2 & 65.1 \\
\hline & Effluent $\mathrm{SBOD}_{5}$ & 23.9 & 50.7 & 25.3 & 51.6 & 36.6 \\
\hline \multirow{2}{*}{$\begin{array}{l}\mathrm{SBOD}_{5} \\
(\mathbf{m g} / \mathbf{l})\end{array}$} & Influent $\mathrm{TBOD}_{5}$ & 21.6 & 29.9 & 24.2 & 26.3 & 24.1 \\
\hline & Effluent $\mathrm{SBOD}_{5}$ & 8.3 & 21.7 & 8.1 & 18.6 & 13.2 \\
\hline
\end{tabular}

Appendix E: Performance of NaOCI doses (Control) (Data used for Table 3.4)

\begin{tabular}{|c|c|c|c|c|c|c|c|c|}
\hline & $\begin{array}{c}\text { Dose } \\
(\mathbf{m g} / \mathbf{l})\end{array}$ & $\begin{array}{c}\text { TCOD } \\
(\mathbf{m g} / \mathbf{l})\end{array}$ & $\begin{array}{c}\text { SCOD } \\
(\mathbf{m g} / \mathbf{l})\end{array}$ & $\begin{array}{c}\text { TSS } \\
(\mathbf{m g} / \mathbf{l})\end{array}$ & $\begin{array}{c}\text { VSS } \\
(\mathbf{m g} / \mathbf{l})\end{array}$ & $\begin{array}{c}\text { STN } \\
(\mathbf{m g} / \mathbf{l})\end{array}$ & $\begin{array}{c}\text { NH4 } \\
(\mathbf{m g} / \mathbf{l})\end{array}$ & $\begin{array}{c}\text { PCOD } \\
(\mathbf{m g} / \mathbf{l})\end{array}$ \\
\hline $\mathrm{CSO}$ & & 98 & 36 & 80 & 60 & 7.3 & 5 & 62 \\
\hline $\mathrm{Blank}$ & & 70 & 29 & 60 & 40 & 7.1 & 5 & 41 \\
\hline $\mathrm{NaOCl}(44)$ & 44 & 59 & 25 & 60 & 40 & 6.8 & 4.9 & 34 \\
\hline $\mathrm{NaOCl}(208)$ & 208 & 56 & 24 & 50 & 50 & 6.6 & 4.8 & 32 \\
\hline $\mathrm{NaOCl}(229)$ & 229 & 55 & 23 & 60 & 40 & 6.3 & 4.8 & 32 \\
\hline $\mathrm{NaOCl}(247)$ & 247 & 57 & 26 & 50 & 40 & 6.3 & 4.8 & 31 \\
\hline
\end{tabular}


Appendix F: Optimization of Fe (VI) synthesized from digested PS filtrate (Data used for Figure 3.7)

\begin{tabular}{|c|c|c|c|c|c|c|c|}
\hline $\begin{array}{c}\text { Dose } \\
(\mathbf{m g} / \mathbf{l})\end{array}$ & & $\begin{array}{c}\text { TCOD } \\
(\mathbf{m g} / \mathbf{l})\end{array}$ & $\begin{array}{c}\text { SCOD } \\
(\mathbf{m g} / \mathbf{l})\end{array}$ & $\begin{array}{c}\text { TSS } \\
(\mathbf{m g} / \mathbf{l})\end{array}$ & $\begin{array}{c}\text { VSS } \\
(\mathbf{m g} / \mathbf{l})\end{array}$ & $\begin{array}{c}\text { TP } \\
(\mathbf{m g} / \mathbf{l})\end{array}$ & $\begin{array}{c}\text { TN } \\
(\mathbf{m g} / \mathbf{l})\end{array}$ \\
\hline \multirow{2}{*}{0.1} & Initial & 110 & 52 & 80 & 60 & 3 & 10 \\
\cline { 2 - 8 } & Final & 44 & 20 & 30 & 20 & 2.1 & 7.5 \\
\hline \multirow{2}{*}{0.2} & Initial & 113 & 54 & 80 & 60 & 3.2 & 10 \\
\cline { 2 - 8 } & Final & 52 & 26 & 35 & 20 & 2.2 & 7.3 \\
\hline \multirow{2}{*}{0.3} & Initial & 119 & 55 & 80 & 60 & 3.2 & 11 \\
\cline { 2 - 8 } & Final & 52 & 24 & 30 & 20 & 2.1 & 8.7 \\
\hline \multirow{2}{*}{0.4} & Initial & 122 & 58 & 80 & 60 & 3 & 10 \\
\cline { 2 - 8 } & Final & 50 & 28 & 45 & 25 & 2 & 6.9 \\
\hline \multirow{2}{*}{0.5} & Initial & 130 & 65 & 80 & 60 & 3.3 & 11 \\
\cline { 2 - 8 } & Final & 90 & 42 & 40 & 20 & 2.1 & 7.5 \\
\hline
\end{tabular}

\begin{tabular}{|c|c|c|c|c|c|c|}
\cline { 2 - 7 } \multicolumn{1}{c|}{} & \multicolumn{7}{c|}{ \% Removal } \\
\hline Dose $(\mathrm{mg} / \mathrm{l})$ & TCOD & SCOD & TSS & VSS & TP & TN \\
\hline 0.1 & 60 & 62 & 63 & 67 & 30 & 25 \\
\hline 0.2 & 54 & 52 & 56 & 67 & 31 & 27 \\
\hline 0.3 & 56 & 56 & 63 & 67 & 34 & 21 \\
\hline 0.4 & 59 & 52 & 44 & 58 & 33 & 31 \\
\hline 0.5 & 31 & 35 & 50 & 67 & 36 & 32 \\
\hline
\end{tabular}




\section{Curriculum Vitae}

Name:

Post-Secondary Education and Degrees:

Honors and Awards
Rohan Gandhi

B.Eng

Chemical Engineering

Vishwakarma Institute of Technology

Pune, Maharashtra, India

2007-2011

Western Graduate Research Scholarship

(WGRS)

The University of Western Ontario London, Ontario, Canada 2012-2013

Graduate Research Assistant

The University of Western Ontario London, Ontario, Canada 2012-2013

Graduate Teaching Assistant The University of Western Ontario London, Ontario, Canada 2012-2013 